


\section{Advies over de Natura 2000-doelensystematiek en Natura 2000-doelen}

Een oriënterende studie ter onderbouwing van de evaluatie van de Natura 2000doelensystematiek en Natura 2000-doelen

A.M. Schmidt ${ }^{1}$, A. van Kleunen ${ }^{2}$, L. Kuiters ${ }^{1}$, J.A.M. Janssen ${ }^{1}$, R.J. Bijlsma ${ }^{1}$, M. van Roomen ${ }^{2}$ en T. van Vreeswijk ${ }^{1}$

1 Wageningen Environmental Research

2 Sovon Vogelonderzoek Nederland

Dit onderzoek is uitgevoerd door Wageningen Environmental Research (Alterra) in opdracht van en gefinancierd door het Ministerie van Economische Zaken, in het kader van het Beleidsondersteunend onderzoekthema Biodiversiteit Terrestrisch (projectnummer BO-11-019.01-006).

Wageningen Environmental Research

Wageningen, januari 2017

Rapport 2779A

ISSN 1566-7197 
Schmidt, A.M., A. van Kleunen, L. Kuiters, J.A.M. Janssen, R.J. Bijlsma, M. van Roomen en T. van Vreeswijk, 2017. Advies over de Natura 2000-doelensystematiek en Natura 2000-doelen; Een oriënterende studie ter onderbouwing van de evaluatie van de Natura 2000-doelensystematiek en Natura 2000-doelen. Wageningen, Wageningen Environmental Research, Rapport 2779A. 90 blz.; 17 fig.; 18 tab.; 30 ref.

In dit rapport wordt verslag gedaan van een verkennend onderzoek ten behoeve van de evaluatie van de Natura 2000-doelensystematiek en Natura 2000-doelen. Advies wordt gegeven over verbeteringen in wijze van formulering van de Natura-doelen en over het bijstellen van de Natura-doelen vanwege de ontwikkelingen die tussentijds (vanaf 2006 tot 2015) hebben plaatsgevonden en op basis van de huidige kennis en informatie.

Trefwoorden: Natura 2000-doelendocument, Natura 2000-doelensystematiek, Natura 2000-doelen, Natura 2000-netwerk, Vogelrichtlijn, Habitatrichtlijn, habitattypen, Vogelrichtlijnsoorten, Habitatrichtlijnsoorten

Dit rapport is gratis te downloaden van http://dx.doi.org/10.18174/404086 of op www.wur.nl/environmental-research (ga naar 'Wageningen Environmental Research' in de grijze balk onderaan). Wageningen Environmental Research verstrekt geen gedrukte exemplaren van rapporten.

() 2017 Wageningen Environmental Research (instituut binnen de rechtspersoon Stichting Wageningen Research), Postbus 47, 6700 AA Wageningen, T 03174807 00, E info.alterra@wur.nl, www.wur.nl/environmental-research. Wageningen Environmental Research is onderdeel van Wageningen University \& Research.

- Overname, verveelvoudiging of openbaarmaking van deze uitgave is toegestaan mits met duidelijke bronvermelding.

- Overname, verveelvoudiging of openbaarmaking is niet toegestaan voor commerciële doeleinden en/of geldelijk gewin.

- Overname, verveelvoudiging of openbaarmaking is niet toegestaan voor die gedeelten van deze uitgave waarvan duidelijk is dat de auteursrechten liggen bij derden en/of zijn voorbehouden.

Wageningen Environmental Research aanvaardt geen aansprakelijkheid voor eventuele schade voortvloeiend uit het gebruik van de resultaten van dit onderzoek of de toepassing van de adviezen.

Wageningen Environmental Research Rapport 2779A | ISSN 1566-7197

Foto omslag: Shutterstock 


\section{Inhoud}

$\begin{array}{ll}\text { Woord vooraf } & 5\end{array}$

$\begin{array}{ll}\text { Management samenvatting } & 7\end{array}$

$1 \quad$ Inleiding $\quad 15$

$\begin{array}{lll}1.1 & \text { Aanleiding } & 15\end{array}$

1.2 Vraagstelling $\quad 16$

$\begin{array}{lll}1.3 & \text { Afbakening } & 17\end{array}$

$\begin{array}{lll}1.4 & \text { Leeswijzer } & 17\end{array}$

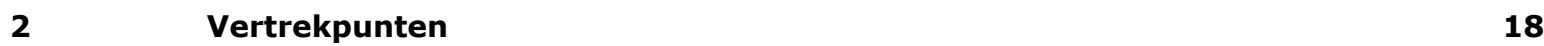

$2.1 \quad$ Natura 2000-doelendocument 19

2.1.1 Wettelijk kader 19

2.1.2 Natura 2000-doelensystematiek 20

2.1.3 Formulering van landelijke doelen (proceslijn 1) 21

2.1.4 Formulering gebiedsdoelen (proceslijn 2) 23

2.2 Aanwijzingsbesluiten $\quad 25$

2.2.1 Functie $\quad 25$

2.2.2 Proces 25

$\begin{array}{ll}2.2 .3 \text { Inhoud } & 26\end{array}$

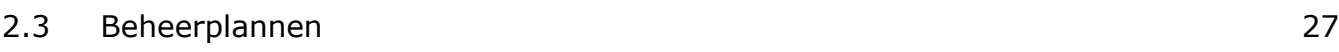

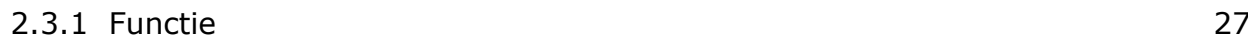

$\begin{array}{ll}2.3 .2 \text { Proces } & 27\end{array}$

$\begin{array}{ll}2.3 .3 \text { Inhoud } & 27\end{array}$

2.4 Rapportages aan de Europese Commissie $\quad 30$

2.4.1 VR artikel 12-rapportage $\quad 30$

2.4.2 HR artikel 17-rapportage 30

2.4.3 Standard Data Forms Natura 2000-gebieden 31

3 Deel I Natura 2000-doelensystematiek $\quad 32$

$3.1 \quad$ Aanleiding en vraagstelling $\quad 32$

3.2 Aanpak 32

3.2.1 Toetsingskader $\quad 32$

3.2.2 Evaluatie op basis van beheerplannen 34

3.2.3 Enquête met voortouwnemers van Natura 2000-gebieden 35

3.3 Resultaten 36

3.3.1 Coherentie (interne samenhang) Natura 2000-doelen 36

3.3.2 Coherent (samenhang met ander beleid) 37

$\begin{array}{ll}3.3 .3 \text { Prioritering } & 40\end{array}$

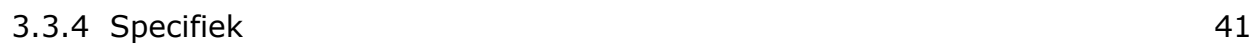

$\begin{array}{ll}3.3 .5 & \text { Meetbaar }\end{array}$

3.3.6 Acceptabel $\quad 46$

$\begin{array}{ll}3.3 .7 \text { Realistisch } & 47\end{array}$

3.3.8 Tijdgebonden $\quad 48$

$\begin{array}{ll}3.3 .9 \text { Consistent } & 49\end{array}$

3.3.10Alomvattend $\quad 50$

3.3.11Robuust $\quad 50$

3.3.12Flexibel $\quad 51$

3.4 Conclusies en aanbevelingen $\quad 53$

3.4.1 Conclusies 53

3.4.2 Aanbevelingen $\quad 55$ 
4.1 Aanleiding en vraagstelling 58

$\begin{array}{lll}4.2 & \text { Aanpak } & 58\end{array}$

4.2.1 Proceslijnen $\quad 58$

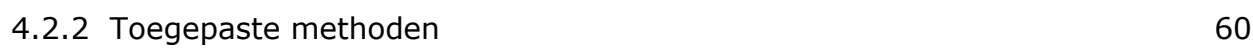

$\begin{array}{ll}4.2 .3 \text { Geraadpleegde bronnen } & 60\end{array}$

$\begin{array}{lll}4.3 & \text { Resultaten } & 61\end{array}$

$\begin{array}{ll}\text { 4.3.1 Landelijke doelen } & 61\end{array}$

$\begin{array}{ll}\text { 4.3.2 Gebiedsdoelen } & 73\end{array}$

$\begin{array}{lll}4.4 & \text { Conclusies en aanbevelingen } & 75\end{array}$

$\begin{array}{ll}\text { 4.4.1 Landelijke doelen } & 75\end{array}$

$\begin{array}{ll}4.4 .2 \text { Gebiedsdoelen } & 76\end{array}$

$\begin{array}{ll}\text { Literatuur } & 78\end{array}$

Bijlage 1 Criteria selectie en begrenzing Natura 2000-gebieden 80

Bijlage 2 Beoordeling relatieve belang gebieden (Bijlage III van de Habitatrichtlijn) $\quad 82$

$\begin{array}{lll}\text { Bijlage } 3 & \text { Beoordeling staat van instandhouding } & 83\end{array}$

$\begin{array}{lll}\text { Bijlage } 4 \text { Geïnventariseerde beheerplannen } & 85\end{array}$

$\begin{array}{lll}\text { Bijlage } 5 & \text { Enquête voortouwnemers } & 86\end{array}$ 


\section{Woord vooraf}

In dit rapport wordt verslag gedaan van een verkennend onderzoek ten behoeve van de evaluatie van de Natura 2000-doelensystematiek en Natura 2000-doelen. Advies wordt gegeven over verbeteringen in wijze van formulering van de Natura-doelen en over het bijstellen van de Natura-doelen, dit vanwege de ontwikkelingen die tussentijds (vanaf 2006 tot 2015) hebben plaatsgevonden en op basis van de huidige kennis en informatie. De daadwerkelijke evaluatie van de Natura 2000-

doelensystematiek en Natura 2000-doelen zal in een later stadium plaatsvinden, omdat het beheerplanproces nog in volle gang was op het moment van dit onderzoek. Het onderzoek is uitgevoerd door Wageningen Environmental Research en Sovon Vogelonderzoek Nederland onder supervisie van een begeleidingscommissie met daarin vertegenwoordigd het ministerie van Infrastructuur en Milieu, het ministerie van Economische Zaken en de provincies. Bij dezen dank ik iedereen die een bijdrage heeft geleverd aan het onderzoek en aan dit rapport.

Anne Schmidt 


\title{
Management samenvatting
}

\section{Korte toelichting op het onderzoek}

\author{
Aanleiding \\ In 2006 is door het ministerie van Landbouw, Natuur en Voedselkwaliteit (LNV), nu het ministerie van \\ Economische Zaken (EZ), het Natura 2000-doelendocument gepubliceerd. In het Natura \\ 2000-doelendocument zijn de Natura 2000-instandhoudingsdoelstellingen (hierna: Natura 2000- \\ doelen) volgens een aangegeven systematiek geformuleerd, gebaseerd op de best beschikbare \\ informatie van dat moment. Gezien een aantal onzekerheden over te verwachten ontwikkelingen, \\ voortkomend uit natuurlijke dynamiek en klimaatverandering, is door destijds het ministerie van LNV \\ een evaluatie voorzien van Natura 2000-doelen, die oorspronkelijk was gepland voor 2015.
}

Ter ondersteuning van de evaluatie van het Natura 2000-doelendocument 2006 is door Alterra en Sovon in 2015-2016 in het kader van het beleidsondersteunend onderzoek binnen thema Terrestrische Biodiversiteit in opdracht van het ministerie van EZ een oriënterend onderzoek uitgevoerd. De resultaten van dit onderzoek vormen een bouwsteen voor desbetreffende evaluatie, die zal plaatsvinden nadat alle aanwijzingen en beheerplannen van de Natura 2000-gebieden definitief zijn en de Europese Fitness Check van de Vogelrichtlijn en Habitatrichtlijn is afgerond.

Het oriënterende onderzoek bestaat uit twee delen. Het eerste deel betreft een analyse van de wijze waarop de Natura 2000-doelen zijn geformuleerd, ofwel een analyse van de Natura 2000doelensystematiek. Het tweede betreft een analyse van de Natura 2000-doelen, ofwel het resultaat van de gevolgde Natura 2000-doelensystematiek. Het betreft dus niet een evaluatie in hoeverre de Natura 2000-doelen zijn bereikt, maar een actualisatie en/of een correctie van de Natura 2000-doelen op basis van de veranderingen die in de tussentijd hebben plaatsgevonden en/of verbeterde kennis en informatie.

\section{Vraagstelling}

\section{Deel I Natura 2000-doelensystematiek}

De onderzoekvragen over de Natura 2000-doelensystematiek zijn:

1. Welke voorwaarden (criteria) worden er gesteld door de Europese Commissie en het rijk aan de formulering van de Natura 2000-doelen en met welke motivatie?

2. Voldoet de formulering van de Natura 2000-doelen in respectievelijk het Natura 2000doelendocument, de aanwijzingsbesluiten en de beheerplannen van de Natura 2000-gebieden ook aan deze voorwaarden, ofwel hoe is hier invulling aan gegeven door Rijk en voortouwnemers?

3. Wat zijn de mogelijke achterliggende oorzaken van het wel/niet voldoen aan deze voorwaarden?

4. Welke consequenties heeft dit voor de realisatie van de Natura 2000-doelen en daarmee samenhangend de doelmatigheid en doeltreffendheid van het Natura 2000-beleid?

De laatste twee vragen zijn lastig te beantwoorden, aangezien er factoren zijn, los van de Natura 2000-doelensystematiek, die van invloed zijn op de realisatie van de instandhoudingsdoelen, zoals politiek-bestuurlijke factoren. Daarom is een terugkoppeling wenselijk, zo niet noodzakelijk, met de actoren die een belangrijke rol spelen in toepassing van de Natura 2000-doelensystematiek, waaronder de voortouwnemers van de Natura 2000-gebieden. 


\section{Deel II Natura 2000-doelen}

De analyse van de Natura 2000 doelen bestaat - conform de Natura 2000-doelensystematiek 2006 uit 2 sporen, te weten een landelijk spoor en een gebiedenspoor. De nadruk binnen dit onderzoek ligt op het gebiedenspoor en specifiek op de (her)selectie van de Natura 2000-gebieden op basis van nieuwe gegevens en/of kennis. Voor de VR-soorten wordt ook een advies gegeven over de bijstelling van een selectie van landelijke en gebiedsdoelen t.a.v. populatiegrootte (zie voor details Van Kleunen et al., 2016).

\section{Landelijk spoor}

De onderzoeksvragen zijn:

1. Zijn er 'nieuwe' habitattypen en soorten ofwel habitattypen en soorten waar nog geen gebieden voor zijn aangewezen en die gezien de hiervoor geldende criteria ${ }^{1}$ wel voor in aanmerking komen?

2. Is het belang van Nederland voor de instandhouding van de 'bestaande' habitattypen en soorten, ofwel soorten en habitattypen waar al gebieden voor zijn geselecteerd en/of aangewezen binnen de EU, in de tussentijd (2006-2015) veranderd?

3. Is de staat van instandhouding van 'bestaande' habitattypen en soorten in de tussentijd (20062015) veranderd?

4. Is het op grond van het voorgaande $(1 \mathrm{t} / \mathrm{m} \mathrm{3}$ ) wenselijk dat bijstellingen (correctie of actualisatie) van de Natura 2000-doelen op landelijk niveau worden doorgevoerd?

5. Zijn de landelijke doelen ecologisch haalbaar?

Onderzoeksvraag 4 wordt maar beperkt beantwoord in dit onderzoek, aangezien de focus ligt op de (her)selectie en de aanwijzing van Natura 2000-gebieden voor 'nieuwe' en 'bestaande' soorten en habitattypen. Over de Natura 2000-doelen t.a.v. de populatiegrootte van VR-soorten wordt wel een advies gegeven over bijstellingen, omdat hier nu betere en actuelere gegevens en kennis over beschikbaar zijn (zie voor details Van Kleunen et al., 2016). Onderzoeksvraag 5 is in dit onderzoek ook beperkt tot de Natura 2000 doelen t.a.v. Vogelrichtlijnsoorten, aangezien dit voor de habitattypen en Habitatrichtlijnsoorten al eerder is geëvalueerd (Bijlsma et al., 2014b).

\section{Gebiedenspoor}

De onderzoeksvragen zijn:

1. Welke Natura 2000-gebieden (bestaande of nieuwe) zijn van belang voor de instandhouding van de 'nieuwe' habitattypen en soorten en zouden geselecteerd en aangewezen moeten worden voor desbetreffende habitattypen en soorten?

2. Is het relatieve belang van de Natura 2000-gebieden voor de instandhouding van 'bestaande' habitattypen en soorten tussentijds (2006-2015) veranderd? Zo ja, is het wenselijk om de selectie en de aanwijzing van de gebieden hierop aan te passen?

Het gebiedenspoor is vooral gericht op de selectie en vervolgens aanwijzing van de Natura 2000gebieden en niet op de formulering van behoud- en herstelopgaven voor habitattypen en soorten in desbetreffende gebieden. Voor de doelen t.a.v. de populatiegrootte van de Vogelrichtlijnsoorten wordt binnen dit onderzoek wel een advies gegeven over wenselijke bijstellingen, omdat hier nu betere en actuelere gegevens en kennis over beschikbaar zijn (zie voor details Van Kleunen et al., 2016).

\section{Aanpak}

Vertrekpunten van dit onderzoek zijn het Natura 2000-doelendocument, de aanwijzingsbesluiten en de op dit moment beschikbare versies van de beheerplannen van de Natura 2000-gebieden. In aanvulling daarop is ook gebruikgemaakt van de recentste nationale rapportages aan de Europese Commissie uit 2013 (artikel 12 VR en artikel $17 \mathrm{HR}$ ).

Qua methodiek is aangesloten bij de filosofie, principes en proceslijnen van het Natura 2000doelendocument. Qua methodiek zijn grotendeels dezelfde selectie- en beoordelingscriteria als in 2006 toegepast. In een technisch achtergrondrapport wordt hier nader op ingegaan (Van Kleunen et al., 2016).

\footnotetext{
1 Deze criteria verschillen tussen de soorten (en habitattypen) van de Habitatrichtlijn en de soorten van de Vogelrichtlijn.
} 


\section{Hoofdbevindingen}

\section{Deel I Natura 2000-doelensystematiek}

\section{Conclusies}

\section{De voorwaarden die door de EC en het Rijk gesteld worden aan de formulering van de Natura 2000-doelen en motivatie}

De voorwaarden die het Rijk stelt aan de formulering van de Natura 2000-doelen in het Natura 2000doelendocument uit 2006 (incl. aanvullende documenten) en de Rijksnatuurvisie, komen grotendeels overeen met die van de Europese Commissie en ook met de Rijksnatuurvisie 2014. De voorwaarden die door de EC en/of het Rijk gesteld worden zijn:

- coherentie (intern): er dient rekening gehouden te worden met de samenhang tussen de Natura 2000doelen op verschillende ruimtelijke schaalniveaus en binnen een schaalniveau, bv. de landelijke doelen en de gebiedsdoelen en de gebiedsdoelen onderling (voorwaarde van de EC en het Rijk);

- coherentie (samenhang met ander beleid): er dient rekening gehouden te worden met de samenhang tussen Natura 2000-opgaven en andere maatschappelijke opgaven (voorwaarde van het Rijk en met minder nadruk van de EC);

- prioritering: er dienen prioriteiten gesteld te worden op basis van het belang van NL voor EU, het belang van de Natura 2000-gebieden voor NL en de urgentie voor het nemen van maatregelen (voorwaarde van de EC en het Rijk);

- SMART: doelen dienen specifiek, meetbaar, acceptabel, realistisch en tijdgebonden en daarmee toetsbaar geformuleerd te worden (voorwaarde van de EC en het Rijk, tijdgebonden geldt voor de EC in die zin dat de staat van instandhouding niet mag verslechteren en dat hier dus op tijd maatregelen voor genomen moeten worden);

- consistent: er moet een vergelijking mogelijk zijn tussen landelijke doelen en gebiedsdoelen en tussen gebiedsdoelen onderling (voorwaarde van de EC);

- alomvattend: alle aspecten van de staat van instandhouding dienen in aanmerking genomen te worden (voorwaarde van de EC);

- robuust: er dient geanticipeerd te worden op natuurlijke dynamiek en klimaatverandering (voorwaarde van het Rijk);

- flexibel: er moet ruimte geboden worden voor een nadere uitwerking in omvang, ruimte, tijd en kwaliteit op regionaal en/of gebiedsniveau (voorwaarde van het Rijk).

De voorwaarden flexibel en robuust zijn voorwaarden die het Rijk stelt. Deze voorwaarden kunnen op verschillende wijze worden geïnterpreteerd. In deze studie is de interpretatie van het Natura 2000doelendocument genomen. De achterliggende motivatie heeft in de meeste gevallen van doen met het streven naar een coherent, doelmatig en doeltreffend beleid (conform de criteria van de Fitness Check).

\section{Wijze waarop wel/niet invulling wordt gegeven aan de voorwaarden voor de formulering van de Natura 2000-doelen}

Hoe goed invulling is gegeven aan de door de EC en rijk gestelde voorwaarden in respectievelijk het Natura 2000-doelendocument, de aanwijzingsbesluiten en de beheerplannen is lastig te beoordelen, aangezien de achterliggende analyses (bv. de toetsing van de haalbaarheid en betaalbaarheid van de Natura 2000-doelen) niet altijd toegankelijk zijn. Men stelt dus bepaalde voorwaarden maar de toetsing ervan ontbreekt, tenminste is niet gedocumenteerd en dus niet te achterhalen.

Ook uit de inventarisatie van de (31) beheerplannen kan niet goed worden opgemaakt hoe er invulling is gegeven aan de voorwaarden, bijvoorbeeld wat betreft de samenhang tussen gebiedsdoelen en landelijke doelen (interne coherentie), de afstemming met andere beleidsdoelen (coherentie met ander beleid) en de prioritering van doelen (zie voor details Vreeswijk et al., 2016).

Wel kan geconcludeerd worden dat de doelen t.a.v. 'kwaliteit' (de kwaliteit van het leefgebied van soorten en de kwaliteit van habitattypen) in tegenstelling tot de doelen t.a.v. 'kwantiteit' (de populatiegrootte van soorten en het oppervlakte van habitattype) in veel gevallen niet SMART en daarmee ook niet toetsbaar zijn geformuleerd. De wijze waarop de doelen t.a.v. kwaliteit zijn uitgewerkt, verschilt sterk tussen de beheerplannen (zie voor details Vreeswijk et al., 2016). 


\section{Wat zijn mogelijke oorzaken van het wel/niet voldoen aan de voorwaarden?}

Het niet voldoen aan de voorwaarden voor de formulering van de Natura 2000-doelen is te verklaren door enerzijds politiek-bestuurlijke factoren en anderzijds door de hiaten in de kennis en informatievoorziening en onduidelijkheden over de voorschriften van de EC en het Rijk. Zo vereist coherentie en prioritering van doelen een goede samenwerking tussen overheden op verschillende bestuurlijke niveaus en met private en maatschappelijke organisaties en vereist de toetsbare formulering van de doelen duidelijke instructies en de beschikbaarheid van gegevens en kennis.

Een andere mogelijke oorzaak lig bij de financiering en aansturing van de uitvoering van de maatregelen. Zo loopt de financiering van de beheermaatregelen grotendeels via het Subsidiestelsel Natuur en Landschapsbeheer (SNL) en het Agrarisch Natuur en Landschapsbeheer (ANLb). Het SNL is gestoeld op de index NL (de natuurbeheertypen). De terreinbeherende organisaties sturen hun beheercyclus dan ook aan op basis van dit stelsel. Watermaatregelen worden veelal via de Kaderrichtlijn Water (KRW) gefinancierd. De relatie met desbetreffende dossiers (SNL, ANLb en KRW) wordt in de beheerplannen vaak genoemd, maar veelal niet expliciet gemaakt (zie voor details Vreeswijk et al., 2016). De vraag is dan ook of het beheerplan daadwerkelijk de functie vervult zoals beoogd wordt (zie paragraaf 2.2.1).

De Natura 2000-doelen zijn gericht op een selectie van soorten (voor VR-soorten uitgebreider dan voor HR-soorten) en op specifieke habitattypen. Voor het beheer van een gebied moet echter rekening gehouden worden met het totale gebied, oftewel het hele ecosysteem (ecosysteembenadering). In de beheerplannen lijkt dit echter niet echt tot zijn recht te komen, aangezien er zelden aanvullende (natuur)doelen worden genoemd (zie Vreeswijk et al., 2016). Het is dan ook niet duidelijk of er sprake is van coherentie tussen verschillende natuurdoelen. Ook hier kan weer de vraag gesteld worden of het beheerplan ook daadwerkelijk de functie vervult zoals wordt beoogd.

\section{Mogelijke consequenties van het niet voldoen aan de voorwaarden die gesteld worden aan de Natura 2000-doelen}

De consequenties van het niet voldoen aan de formulering van de Natura 2000-doelen gestelde voorwaarden, zijn onder meer incoherentie en gebrek aan prioritering en sturing met als gevolg een ondoelmatig en ondoeltreffend beleid. Dit kan echter niet zonder meer worden geconstateerd op basis van dit onderzoek, omdat de informatie hierover veelal ontbreekt, bijvoorbeeld in de beheerplannen.

\section{Aanbevelingen}

\section{Eenduidige interpretatie en beleidsmatige onderbouwing van de voorwaarden aan doelformulering}

Aanbevolen wordt om een eenduidige interpretatie te geven van de voorwaarden die aan de formulering van de Natura 2000-doelen worden gesteld en deze ook goed te onderbouwen met een beleidstheorie. Zo verschilt de wijze waarop de voorwaarden 'robuust' en 'flexibel' worden geïnterpreteerd tussen dit onderzoek en het onderzoek t.b.v. de Fitness Check (Broekmeijer et al., 2016), zo ook de verwachtingen hierbij voor een mogelijke verbetering van de Natura 2000-doelensystematiek. Het binnen dit onderzoek ontwikkelde toetsingskader en nadere uitwerking kan hiervoor als uitgangspunt/startpunt worden gebruikt.

\section{Functie beheerplannen herbezien}

Verder wordt aanbevolen om de functie van het beheerplan nog eens te bezien, onder andere wat betreft het bewaken van de coherentie en prioritering van de Natura 2000-doelen. Uit de beheerplannen kan bijvoorbeeld niet goed worden opgemaakt of en in hoeverre de Natura 2000doelen samenhangen met andere (natuur)doelen. De ruimte voor nadere uitwerking van de Natura 2000-doelen in de beheerplannen is ook gering, omdat veel al in de aanwijzingsbesluiten is/wordt vastgelegd, bijvoorbeeld de selectie van de soorten en habitattypen en de behoud- en herstelopgaven voor desbetreffende soorten en habitattypen. 


\section{Voorschriften voor monitoring en beoordeling Natura 2000-doelen verbeteren}

Aanbevolen wordt om de voorschriften voor de monitoring en beoordeling van de Natura 2000-doelen beter uit te werken, zodat duidelijk is hoe de Natura 2000-doelen SMART te formuleren en te toetsen zijn. Vreeswijk van et al. (2016) geven suggesties aan hoe de checklist voor het opstellen van beheerplannen te verbeteren.

\section{Gegevens- en informatievoorziening verbeteren}

Voor de formulering en toetsing van Natura 2000-doelen zijn gegevens nodig van goede kwaliteit (actueel, volledig, juist etc.). Die zijn op dit moment lang niet altijd beschikbaar. Aanbevolen wordt om de gegevens- en informatievoorziening te verbeteren, vooral wat betreft de HR-soorten en habitattypen.

\section{Deel II Natura 2000-doelen}

\section{Conclusies}

Landelijke spoor

\section{Selectie van 'nieuwe' soorten en habitattypen}

Op basis van het huidige onderzoek komen 1 'nieuw' habitattype, 2 'nieuwe' HR-soorten en 19 'nieuwe' VR-soorten in aanmerking om gebieden voor te selecteren en aan te wijzen. In de meeste gevallen kan daarbij worden volstaan met de selectie van al aangewezen gebieden. Voor 17 habitattypen zijn definities tussentijds aangepast. Ingeschat is dat dit voor 7 habitattypen mogelijk leidt tot wenselijke aanpassingen in de selectie en aanwijzing van gebieden.

\section{NL belang voor EU, Atlantische regio en/of Oost-Atlantische vliegroute 'bestaande' soorten en habitattypen}

Het belang van Nederland voor de EU, de Atlantische regio en/of de Oost Atlantische Vliegroute (het laatste geldt alleen voor de trekvogels) voor de 'bestaande' habitattypen en soorten is geactualiseerd. Er zijn 40 habitattypen waarvoor het EU-belang is aangepast (33 lager en 7 hoger). Deze wijzigingen zijn het gevolg van een andere werkwijze en verbeterde gegevens. Voor $21 \mathrm{HR}$-soorten is het EU-belang aangepast (13 lager en 7 hoger). Nog niet onderzocht is of deze aanpassingen het wenselijk maken om de landelijke doelen bij te stellen. Voor 14 broedvogels is het EU-belang aangepast (13 lager en 1 hoger). Voor de trekvogels is het belang ten opzichte van de Flyway-populatie bepaald. Voor 13 trekvogels is dit belang aangepast (10 lager en 3 hoger). De reden hiertoe zijn betere gegevens (populatieschattingen) voor de Flyway-populaties. Deze wijzigingen bij de vogels geven geen aanleiding om de landelijke doelen bij te stellen.

\section{Staat van instandhouding 'bestaande' soorten en habitattypen}

Voor de habitattypen en HR-soorten is de staat van instandhouding opnieuw - ten opzichte van de periode 2001-2006 - beoordeeld in de HR artikel 17-rapportage over de periode 2007-2012 (Schmidt en Adams, 2015). Voor de meeste habitattypen en HR-soorten betrof dat een correctie op basis van verbeterde kennis en informatie en niet zozeer een daadwerkelijke verandering in de staat van instandhouding. Voor deze habitattypen en HR-soorten is binnen dit onderzoek nog niet onderzocht of de Natura 2000-doelen hierop aangepast zouden moeten worden. Voor de VR-soorten is de 'indicatieve' staat van instandhouding binnen het huidige onderzoek vastgesteld (Foppen et al., 2016) en vergeleken met de staat van instandhouding zoals vastgesteld in het Natura 2000-doelendocument uit 2006. Op basis van deze vergelijking kan worden geconcludeerd dat de staat van instandhouding van een aantal broedvogels verbeterd is (Foppen et al., 2016). Binnen dit onderzoek wordt advies gegeven over de bijstelling van de landelijke doelen t.a.v. populatiegrootte van VR-soorten (Kleunen van et al., 2016).

\section{Ecologische haalbaarheid 'bestaande' VR-soorten}

Het blijkt dat er voor veel vogelsoorten nog grote knelpunten zijn om de landelijke instandhoudingsdoelen voor de VR-soorten te halen en dat deze voor de broedvogelpopulaties moeilijker te halen zijn dan voor de niet-broedvogelpopulaties. Puur op ecologische gronden zijn die knelpunten echter wel oplosbaar, zeker op de langere termijn (2044 of later), omdat veel knelpunten toch vooral met oorzaken hier in Nederland zelf samenhangen die in principe met beheer en inrichting kunnen worden aangepakt (Foppen et al., 2016). 


\section{Selectie gebieden voor 'nieuwe' soorten en habitattypen}

Voor 1 'nieuw' habitattype (riffen van open zee), 2 'nieuwe' HR-soorten (de otter en de geelgerande waterroofkever) en 19 'nieuwe' VR-soorten wordt binnen dit onderzoek advies gegeven welke gebieden te selecteren (Van Kleunen et al., 2016). Aangezien veranderende definities van habitattypen ook kunnen leiden tot wenselijke aanpassingen in de selectie en aanwijzing van gebieden, is dit binnen dit onderzoek ook ingeschat en wordt ook een aantal nieuw te selecteren en aan te wijzen gebieden genoemd voor de herdefinieerde habitattypen (Van Kleunen et al., 2016).

\section{Selectie gebieden voor 'bestaande' soorten en habitattypen}

Voor de 'bestaande' habitattypen en soorten is mede op basis van het Standaardgegevensformulier uit 2015 en voor de VR-soorten ook op basis van de binnen dit onderzoek geactualiseerde informatie over de populatiegrootte (de 'aantallen') van VR-soorten advies gegeven welke bijstellingen door te voeren in de selectie van de gebieden (Van Kleunen et al., 2016). Samenvattend gaat het om 212 habitattype-gebiedscombinaties (202 erbij en 10 eraf), 89 HR-soort-gebiedscombinaties ( 83 erbij en 6 eraf) en 393 VR-soort-gebiedscombinaties ( 393 erbij). Hierbij zitten voor de VR-soorten in totaal 79 nog niet aangewezen gebieden. Het gros van de aanvullende soort-gebiedscombinaties heeft echter betrekking op al bestaande gebieden en wat de vogels betreft, vooral op doelen voor slaapplaatsfuncties waarvoor de huidige kennis aanmerkelijk is toegenomen ten opzichte van 2006.

\section{Bijstelling gebiedsdoelen t.a.v. de populatiegrootte van VR-soorten}

Voor 2 bestaande broedvogelsoort-gebiedscombinaties wordt er voorgesteld de populatiedoelstelling te wijzigen. Voor 147 bestaande niet-broedvogelsoort-gebiedscombinaties worden nieuwe populatiedoelstellingen voorgesteld of wordt aangegeven dat de huidige populatiedoelstelling voor de foerageer- en of slaapplaatsfunctie zou moeten worden aangepast, vanwege uiteenlopende redenen.

\section{Aanbevelingen}

\section{Selectie soorten en habitattypen}

De selectiecriteria voor de VR-soorten (bv. het geconcentreerd voorkomen en vaste slaapplaatsen) waar gebieden voor aan te wijzen, zouden aangescherpt kunnen worden. Aanbevolen wordt om deze selectie transparanter te maken door concrete grenswaarden te hanteren.

\section{Actualisatie relatief belang NL voor EU Atlantische regio en/of Oost-Atlantische vliegroute Voor een vrij groot aantal soorten en habitattypen is het belang van NL voor de EU aangepast. De achterliggende redenen zijn voornamelijk verbeterde gegevens. Of deze aanpassingen ook leiden tot wenselijke aanpassingen in de landelijke doelen, is binnen dit onderzoek niet verder onderzocht. De verwachting is dat dit niet tot veel bijstellingen zal leiden. Aanbevolen wordt om dit bij de daadwerkelijke evaluatie van de Natura 2000-doelen nader te bekijken.}

\section{Actualisatie staat van instandhouding}

De veranderingen in de staat van instandhouding van HR-soorten en habitattypen zijn grotendeels te wijten aan verbeterde gegevens en kennis. Binnen dit onderzoek is niet onderzocht of dit leidt tot wenselijke aanpassingen in de 2000-doelen. Aanbevolen wordt om dit bij de daadwerkelijke evaluatie van de Natura 2000-doelen nader te bekijken. Voor de VR-soorten wordt door de EC geen beoordeling gevraagd van de staat van instandhouding. Voor een analyse van de ecologische haalbaarheid van landelijke doelen is dit echter wel noodzakelijk. Vandaar dat binnen dit onderzoek de 'indicatieve' staat van instandhouding van VR-soorten is bepaald (Foppen et al., 2016). Uit de vergelijking met de staat van instandhouding zoals beoordeeld in het Natura 2000-doelendocument uit 2006, blijkt dat er vooral een verbetering te zien is bij een aantal broedvogels (Foppen et al., 2016). Aanbevolen wordt om ook voor de VR-soorten een beoordeling uit te voeren van de staat van instandhouding.

\section{Bijstellingen doelen t.a.v. populatiegrootte VR-soorten}

Binnen dit onderzoek wordt voorgesteld om voor een aantal VR-soorten - waar nog geen kwantitatief doel voor was vastgesteld - alsnog een kwantitatief doel vast te stellen. Voor de watervogels is het nu ook mogelijk om seizoengemiddelden te bepalen. De methodiek is inmiddels ook verbeterd.

Aanbevolen wordt om de Natura 2000-doelen hierop aan te passen. 


\section{Ecologische haalbaarheid landelijke doelen}

De evaluatie van de ecologische haalbaarheid van de doelen t.a.v. de VR-soorten wijst uit dat deze doelen op langere termijn haalbaar lijken te zijn ondanks de gevolgen van klimaatverandering (Foppen et al., 2016). In het Natura 2000-doelendocument is naar haalbaarheid en betaalbaarheid gekeken, maar dit is niet onderbouwd zoals nu het geval is door Bijlsma et al. (2014b) en Foppen et al. (2016). Aanbevolen wordt om de conclusies van Foppen et al. en Bijlsma et al. (2014b) bij de daadwerkelijke evaluatie van de Natura 2000-doelen mee te wegen.

\section{Selectie gebieden 'nieuwe' soorten en habitattypen}

Aanbevolen wordt om de voorgestelde gebieden voor nieuwe soorten en habitattypen aan te wijzen. Niet voor alle 'nieuwe' soorten en habitattypen zijn echter goede gegevens beschikbaar. Voor de VRsoorten moet mogelijk worden gewerkt met gemodelleerde abundantiekaarten. Voor de selectie van gebieden voor zeldzame broedvogels die van nature in lage dichtheden voorkomen, wordt aangeraden de selectiecriteria (voor de aanwijzing van de gebieden) aan te passen. Bedreigde broedvogels die gezien de huidige criteria buiten de boot dreigen te vallen, kunnen toegevoegd worden aan gebieden die zijn aangewezen voor andere vogelsoorten. Voor bedreigde trekvogels (doortrekkers en overwinteraars) wordt dit ook aangeraden.

\section{Selectie gebieden 'bestaande' soorten en habitattypen}

Aanbevolen wordt om de voorgestelde gebieden voor de 'bestaande' soorten en habitattypen aan te wijzen en hier ook al rekening mee te houden bij de monitoring. De vraag is wanneer gezien het nog lopende beheerplanproces.

\section{Bijstellingen gebiedsdoelen t.a.v. populatiegrootte VR-soorten}

Net als voor de landelijk doelen zijn de gebiedsdoelen t.a.v. populatiegrootte van VR-soorten geactualiseerd en gekwantificeerd op basis van verbeterde gegevens en kennis. Aanbevolen wordt om de Natura 2000-doelen hierop aan te passen. 


\section{$1 \quad$ Inleiding}

\section{$1.1 \quad$ Aanleiding}

In 2006 is door het ministerie van Landbouw, Natuur en Voedselkwaliteit (LNV), nu het ministerie van Economische Zaken (EZ), het Natura 2000-doelendocument gepubliceerd. In het Natura 2000doelendocument zijn de Natura 2000-instandhoudingsdoelstellingen (hierna: Natura 2000-doelen) volgens een aangegeven systematiek geformuleerd, gebaseerd op de best beschikbare informatie van dat moment. Gezien een aantal onzekerheden over te verwachten ontwikkelingen, voortkomend uit natuurlijke dynamiek en klimaatverandering, is destijds door het ministerie van LNV een evaluatie voorzien van Natura 2000-doelendocument, oorspronkelijk gepland voor 2015 (zie tekstbox).

Natura 2000-doelendocument (pagina 6)

Het Natura 2000-doelendocument is gebaseerd op de best beschikbare informatie met betrekking tot de staat van instandhouding van soorten en habitattypen waarvoor Nederland een verantwoordelijkheid heeft opgenomen in Europees verband en de best beschikbare informatie met betrekking tot autonome en gewenste ontwikkelingen in de 162 Natura 2000-gebieden. Gezien een aantal onzekerheden over te verwachten ontwikkelingen voortkomend uit natuurlijke dynamiek en klimaatveranderingen, is voor het jaar 2015 voorzien in een evaluatie van het doelendocument, indien noodzakelijk zal ook tot wijziging van de ter zake doende aanwijzingsbesluiten worden overgegaan. De evaluatie wordt gelijktijdig uitgevoerd met de geplande evaluatie in het kader van de Kaderichtlijn Water. Daarnaast worden de doelen herijkt en zo nodig bijgesteld bij aanwijzing van gebieden en bij opstelling van beheerplannen. (Ministerie van Landbouw Natuur en Voedselkwaliteit, 2006).

Naast onzekerheden over de te verwachten ontwikkelingen voortkomend uit natuurlijke dynamiek en klimaatverandering zijn er nog meer redenen voor de evaluatie van het Natura 2000-doelendocument, namelijk de ontwikkelingen als gevolg van genomen maatregelen (bv. de herintroductie van soorten en waterkwaliteitsverbeteringen) en drukfactoren (bv. verdroging en vermesting), zo ook voortschrijdend inzicht en nieuwe kennis (bv. de herdefinitie van habitattypen) en een verbeterde informatievoorziening (bv. de beschikbaarheid van habitattypenkaarten en de resultaten van slaapplaatsenonderzoek bij vogels).

Ter ondersteuning van de evaluatie van het Natura 2000-doelendocument 2006 is door Alterra en Sovon in 2015-2016 in het kader van het beleidsondersteunend onderzoek binnen thema Terrestrische Biodiversiteit in opdracht van het ministerie van EZ een oriënterend onderzoek uitgevoerd. De resultaten van dit onderzoek vormen een bouwsteen voor de betreffende evaluatie, die zal plaatsvinden nadat alle aanwijzingen en beheerplannen van de Natura 2000-gebieden definitief zijn en de Europese Fitness Check van de Vogelrichtlijn en Habitatrichtlijn is afgerond.

Het oriënterende onderzoek bestaat uit twee delen. Het eerste deel betreft een analyse van de wijze waarop de Natura 2000-doelen zijn geformuleerd, ofwel een analyse van de Natura 2000doelensystematiek. Het tweede betreft een analyse van de Natura 2000-doelen, ofwel het resultaat van de gevolgde Natura 2000-doelensystematiek. Het betreft dus niet een evaluatie in hoeverre de Natura 2000-doelen zijn bereikt, maar een actualisatie en/of een correctie van de Natura 2000-doelen op basis van de veranderingen die in de tussentijd hebben plaatsgevonden en/of op basis van verbeterde kennis en informatie. 


\subsection{Vraagstelling}

\section{Deel I Natura 2000-doelensystematiek}

De onderzoekvragen over de Natura 2000-doelensystematiek zijn:

1. Welke voorwaarden (criteria) worden er gesteld door de Europese Commissie en het Rijk aan de formulering van de Natura 2000-doelen en met welke motivatie?

2. Voldoet de formulering van de Natura 2000-doelen in respectievelijk het Natura 2000doelendocument, de aanwijzingsbesluiten en de beheerplannen van de Natura 2000-gebieden ook aan deze voorwaarden, ofwel hoe is hier invulling aan gegeven door Rijk en voortouwnemers?

3. Wat zijn de mogelijke achterliggende oorzaken van het wel/niet voldoen aan deze voorwaarden?

4. Welke consequenties heeft dit voor de realisatie van de Natura 2000-doelen en daarmee samenhangend de doelmatigheid en doeltreffendheid van het Natura 2000-beleid?

\section{Deel II Natura 2000-doelen}

De analyse de Natura 2000 doelen bestaat uit 2 sporen, te weten een landelijk spoor en een gebiedenspoor. De nadruk ligt op het gebiedenspoor en specifiek op de selectie van de Natura 2000gebieden. Voor de VR-soorten wordt ook een concreet advies gegeven over bijstelling van de doelen t.a.v. populatiegrootte (landelijk en per gebied), aangezien hier nieuwe gegevens en kennis over beschikbaar zijn (zie Kleunen et al., 2016).

\section{Landelijke spoor}

De onderzoeksvragen zijn:

1. Zijn er 'nieuwe' habitattypen en soorten, ofwel habitattypen en soorten waar nog geen gebieden voor zijn aangewezen en die gezien de hiervoor geldende criteria wel voor in aanmerking komen?

2. Is het belang van Nederland voor de instandhouding van de 'bestaande' habitattypen en soorten, ofwel habitattypen en soorten waar al gebieden voor zijn geselecteerd en/of aangewezen binnen de EU in de tussentijd (2006-2015) veranderd?

3. Is de staat van instandhouding van 'bestaande' habitattypen en soorten in de tussentijd (20062015) veranderd?

4. Is het op grond van het voorgaande ( $1 \mathrm{t} / \mathrm{m} \mathrm{3}$ ) wenselijk dat bijstellingen (correctie of actualisatie) van de Natura 2000-doelen op landelijk niveau worden doorgevoerd?

5. Zijn de landelijke doelen ecologisch haalbaar?

Onderzoeksvraag 4 wordt maar beperkt beantwoord in dit onderzoek, aangezien de focus ligt op de selectie en de aanwijzing van Natura 2000-gebieden voor 'nieuwe' en 'bestaande' soorten en habitattypen (zie volgende paragraaf). Over de Natura 2000-doelen t.a.v. de populatiegrootte van VR-soorten wordt wel een advies gegeven over bijstellingen, gezien het feit dat hier nu betere en actuele gegevens over beschikbaar zijn en de inzichten tussentijds ook zijn veranderd (zie voor details Van Kleunen et al., 2016). Onderzoeksvraag 5 is in dit onderzoek ook beperkt tot de Natura 2000doelen t.a.v. Vogelrichtlijnsoorten, aangezien dit voor de habitattypen en Habitatrichtlijnsoorten al eerder is geëvalueerd (Bijlsma et al., 2014b).

\section{Gebiedenspoor}

De onderzoeksvragen zijn (het gebiedenspoor:

1. Welke (nieuwe of bestaande) Natura 2000-gebieden zijn van belang voor de instandhouding van de 'nieuwe' habitattypen en soorten en zouden geselecteerd en aangewezen moeten worden voor desbetreffende habitattypen en soorten?

2. Is het relatieve belang van de Natura 2000-gebieden voor de instandhouding van 'bestaande' habitattypen en soorten tussentijds (2006-2015) veranderd? Zo ja, is het wenselijk om de selectie en de aanwijzing van de gebieden hierop aan te passen?

Het gebiedenspoor is vooral gericht op de selectie en vervolgens aanwijzing van de Natura 2000gebieden en niet op de formulering van behoud- en herstelopgaven voor habitattypen en soorten in deze gebieden. Voor de doelen t.a.v. de populatiegrootte van de Vogelrichtlijnsoorten wordt binnen dit onderzoek wel een advies gegeven over wenselijke bijstellingen, dit gezien het feit dat hier nu betere en actuele gegevens voor beschikbaar zijn en de inzichten (o.a. qua methodiek) tussentijds zijn veranderd (zie Van Kleunen et al. (2016)). Dit is samengevat in paragraaf 4.3.2.2. 


\subsection{Afbakening}

Dit onderzoek heeft als doel een advies te geven over de wijze van formulering van de Natura 2000doelen en een eventuele bijstelling (een actualisatie of een correctie) van de Natura 2000-doelen. Het is nadrukkelijk niet de bedoeling om een beleidsevaluatie uit te voeren en om de doelmatigheid en doeltreffendheid van het Natura 2000-beleid te beoordelen.

Met Natura 2000-doelen (landelijk en per gebied) worden hier bedoeld de instandhoudingsdoelen voor:

3. de habitattypen van Annex I en de soorten van Annex II van de Habitatrichtlijn,

4. de vogelsoorten van Annex I van de Vogelrichtlijn en de geregeld voorkomende trekvogels (niet op Annex I) conform artikel 4.2 van de Vogelrichtlijn.

De soorten van Annex IV en V van de Habitatrichtlijn en de vogelsoorten van de Vogelrichtlijn die niet kwalificeren voor de aanwijzing van gebieden komen hier dus niet aan de orde.

Beleidsmatige ontwikkelingen, zoals de decentralisatie van het natuurbeleid, de Programmatische Aanpak Stikstof (PAS) en de nieuwe Wet Natuurbescherming zijn in dit onderzoek niet expliciet meegenomen. Er is vooral gekeken naar de ontwikkelingen in de verspreiding en de omvang (oppervlakte en populatiegrootte) van habitattypen en HR- en VR-soorten en de consequenties die dat heeft voor de formulering van de Natura 2000-doelen. Er is niet gekeken naar de oorzaken van desbetreffende veranderingen.

In 2006 was men in de veronderstelling dat het aanwijzings- en beheerplanproces in 2015 zou zijn afgerond. Dit is echter niet gehaald. Dit betekent dat de daadwerkelijke evaluatie zoals oorspronkelijk beoogd in het Natura 2000-doelendocument beter kan worden uitgevoerd op het moment dat deze processen wel zijn afgerond. Op het moment van uitvoering van dit onderzoek waren de beheerplannen nog grotendeels in ontwikkeling, dus was er geen compleet overzicht van de nadere uitwerking van de Natura 2000-doelen in deze beheerplannen.

In het kader van dit onderzoek is een selectie van beheerplannen van de Natura 2000-gebieden doorgenomen. Dit met de bedoeling om te evalueren hoe men de Natura 2000-doelen nader heeft uitgewerkt in omvang, ruimte en tijd (en kwaliteit). Het is nadrukkelijk niet de bedoeling van dit onderzoek om de kwaliteit van de beheerplannen te evalueren.

\subsection{Leeswijzer}

Hoofdstuk 2 betreft een toelichting op de vertrekpunten van dit onderzoek, te weten het Natura 2000doelendocument uit 2006, de aanwijzingsbesluiten en de beheerplannen van de Natura 2000-gebieden en de rapportages aan de Europese Commissie. In dit hoofdstuk wordt samengevat welke beleidsmatige keuzes destijds zijn gemaakt bij de formulering van de Natura 2000-doelen.

Hoofdstuk 3 betreft de analyse van de Natura 2000-doelensystematiek. Hoofdstuk 4 betreft de analyse van de Natura 2000-doelen. Beide hoofdstukken (3-4) zijn zelfstandig leesbaar en beschrijven achtereenvolgens aanleiding en vraagstelling, aanpak, resultaten, conclusies en aanbevelingen.

Er zijn drie technische achtergrondrapporten bij dit rapport, waarin in meer detail wordt ingegaan op respectievelijk de analyse van de Natura 2000-doelensystematiek op basis van beheerplannen (Vreeswijk et al., 2016), de analyse van de ecologische haalbaarheid van de Natura 2000instandhoudingsdoelen voor vogels (Foppen et al., 2016) en de analyse van de Natura 2000-doelen t.a.v. een eventuele bijstelling van de Natura 2000-doelen (Van Kleunen et al., 2016). 


\section{Vertrekpunten}

Hét vertrekpunt van dit onderzoek is het Natura 2000-doelendocument uit 2006 (ministerie van Landbouw, Natuur en Voedselkwaliteit, 2006) en daaropvolgend de aanwijzingsbesluiten en de beheerplannen van de Natura 2000-gebieden. In aanvulling hierop wordt in dit onderzoek ook gebruikgemaakt van de rapportages op grond van artikel 12 van de Vogelrichtlijn (Van Kleunen, 2013), artikel 17 van de Habitatrichtlijn (Schmidt en Adams, 2015) en de Standard Data Forms van de Natura 2000-gebieden (Van Kleunen et al., 2014; Ottburg en Janssen, 2014; Janssen et al., 2014). Deze documenten staan niet los van elkaar, maar hangen onderling samen, zoals geïllustreerd in Figuur 1.

Natura 2000-doelendocument (2006)

Formulering
instandhoudingsdoelen soorten en
habitattypen landelijk en - via
Natura 2000-landschappen - op
gebiedsniveau
Aanwijzingsbesluiten
(2006-nu)
Begrenzing en aanwijzing Natura
2000-gebied voor instandhouding
soorten en habitattypen
Beheerplannen
(2006-nu)
Nadere uitwerking (omvang, tijd
en ruimte) instandhoudingsdoelen
soorten en habitattypen op
gebiedsniveau

VR art 12 en HR art. 17 rapportages (2013-2014)

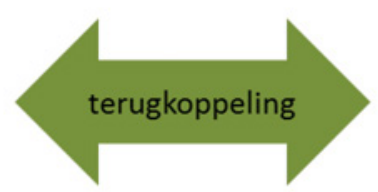

Beoordeling staat van instandhouding $H R$-soorten en habitattypen landelijk / per biogeografische regio (voor $V R$ soorten alleen onderliggende gegevens)

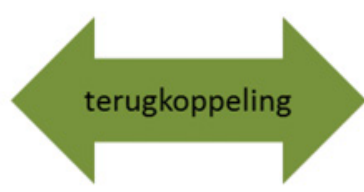

Figuur 1 De samenhang tussen het Natura 2000-doelendocument 2006, de aanwijzingsbes/uiten, de beheerplannen en de VR art. 12- en HR art. 17-rapportage en de Standaard Data Forms.

In het Natura 2000-doelendocument uit 2006 zijn de Natura 2000-doelen geformuleerd op landelijk niveau en via de kernopgaven per Natura 2000-landschap ook op gebiedsniveau. Het document dient als kader voor de aanwijzingsbesluiten en geeft sturing aan de beheerplannen van de Natura 2000gebieden (Ministerie van Landbouw, Natuur en Voedselkwaliteit, 2006). De omvang, de begrenzing en de instandhoudingsdoelen van de Natura 2000-gebieden zijn/worden juridisch vastgelegd in de aanwijzingsbesluiten. In de beheerplannen worden de instandhoudingsdoelen op gebiedsniveau nader uitgewerkt in omvang, ruimte en tijd (en kwaliteit) en worden maatregelen gepland voor de realisatie van deze doelen.

De staat van instandhouding van HR-soorten (Annex II, IV en V) en habitattypen (Annex I) wordt zesjaarlijks op landelijk niveau (per biogeografische regio) beoordeeld en hierover wordt gerapporteerd naar de EC via de artikel 17 HR-rapportage. De VR artikel 12-rapportage bevat geen beoordeling van de staat van instandhouding, maar wel de onderliggende gegevens over de verspreiding en populatiegrootte van VR-soorten. De eerste HR-rapportage met staat van instandhouding is in 2008 bij de EC ingediend; de staat van instandhouding die als basis is gebruikt 
voor het doelendocument wijkt iets af van de in 2008 gerapporteerde. De recentste HR- en VR-rapportages zijn in 2013/2014 ingediend (Schmidt en Adams, 2015; Van Kleunen et al., 2013). In de Standard Data Forms (de SDF's) wordt het relatieve belang van het Natura 2000-gebied voor de instandhouding van soorten en habitattypen gerapporteerd aan de EC, dit mede als onderbouwing van de selectie en aanwijzing van de Natura 2000-gebieden (zie Bijlage 2). Er dient regelmatig een update van de SDF's verstuurd te worden naar de EC, afhankelijk van de ontwikkelingen in de Natura 2000gebieden als gevolg van bijvoorbeeld genomen maatregelen en drukfactoren.

In de onderstaande paragrafen worden de in dit onderzoek geraadpleegde documenten kort toegelicht. Wat het Natura 2000-doelendocument betreft, wordt eerst ingegaan op de systematiek voor het formuleren van de Natura 2000-doelen en vervolgens op de daadwerkelijke formulering van de Natura 2000-doelen, ofwel de toepassing van de Natura 2000-doelensystematiek. Wat betreft de aanwijzingsbesluiten en de beheerplannen van de Natura 2000-gebieden wordt ingegaan op respectievelijk de functie ervan, het proces van de totstandkoming en de inhoud. Wat betreft de EUrapportages wordt een korte toelichting gegeven op de rapportageformats met de ecologische informatie over habitattypen, HR- en VR-soorten, die in dit onderzoek zijn gebruikt.

\subsection{Natura 2000-doelendocument}

\subsubsection{Wettelijk kader}

De doelen van de Vogelrichtlijn en de Habitatrichtlijn (zie tekstbox) zijn in Nederland vertaald naar instandhoudingsdoelen op landelijk niveau en op gebiedsniveau. Dit wordt niet verplicht gesteld door de EC, maar biedt wel een noodzakelijk handvat voor besluitvorming over te nemen beleids- en beheermaatregelen en in te zetten middelen en voor toezicht, handhaving en vergunningverlening.

Doelen van de Vogelrichtlijn en de Habitatrichtlijn

\section{Artikel 1 en 2 van de Vogelrichtlijn}

Artikel 1

1. Deze richtlijn heeft betrekking op de instandhouding van alle natuurlijke in het wild levende vogelsoorten op het Europese grondgebied van de Lid-Staten waarop het Verdrag van toepassing is. Zij betreft de bescherming, het beheer en de regulering van deze soorten en stelt regels voor de exploitatie daarvan.

2. Deze richtlijn is van toepassing op vogels, hun eieren, hun nesten en hun leefgebieden.

3. Deze richtlijn is niet van toepassing op Groenland.

Artikel 2

De Lid-Staten nemen alle nodige maatregelen om de populatie van de in artikel 1 bedoelde soorten op een niveau te houden of te brengen dat met name beantwoordt aan de ecologische, wetenschappelijke en culturele eisen, waarbij zij tevens rekening houden met economische en recreatieve eisen.

\section{Artikel 2 van de Habitatrichtlijn}

1. Deze richtlijn heeft tot doel bij te dragen aan het waarborgen van de biologische diversiteit door het in stand houden van de natuurlijke habitats en de wilde flora en fauna op het Europese grondgebied van de Lid-Staten waarop het Verdrag van toepassing is.

2. De op grond van deze richtlijn genomen maatregelen beogen de natuurlijke habitats en de wilde dieren plantensoorten van communautair belang in een gunstige staat van instandhouding te behouden of te herstellen.

3. In de op grond van deze richtlijn genomen maatregelen wordt rekening gehouden met de vereisten op economisch, sociaal en cultureel gebied, en met de regionale en lokale bijzonderheden.

Artikel 6 van de Habitatrichtlijn, dat naast de Habitatrichtlijngebieden ook van toepassing is op de Vogelrichtlijngebieden, vereist dat er op gebiedsniveau instandhoudingsdoelen worden geformuleerd om de passende maatregelen te treffen (artikel 6.2) en voor de passende beoordeling (artikel 6.3), zie tekstbox. De Europese Commissie licht dit ook uitgebreid toe in de Commission Note on Setting Natura Conservation Objectives (Europese Commissie, 2012). 
1. De Lid-Staten treffen voor de speciale beschermingszones de nodige instandhoudingsmaatregelen; deze behelzen zo nodig passende specifieke of van ruimtelijke-ordeningsplannen deel uitmakende beheersplannen en passende wettelijke, bestuursrechtelijke of op een overeenkomst berustende maatregelen, die beantwoorden aan de ecologische vereisten van de typen natuurlijke habitats van Bijlage I en de soorten van Bijlage II die in die gebieden voorkomen.

2. De Lid-Staten treffen passende maatregelen om ervoor te zorgen dat de kwaliteit van de natuurlijke habitats en de habitats van soorten in de speciale beschermingszones niet verslechtert en er geen storende factoren optreden voor de soorten waarvoor de zones zijn aangewezen voor zover die factoren, gelet op de doelstellingen van deze richtlijn, een significant effect zouden kunnen hebben.

3. Voor elk plan of project dat niet direct verband houdt met of nodig is voor het beheer van het gebied, maar afzonderlijk of in combinatie met andere plannen of projecten significante gevolgen kan hebben voor zo'n gebied, wordt een passende beoordeling gemaakt van de gevolgen voor het gebied, rekening houdend met de instandhoudingsdoelstellingen van dat gebied. Gelet op de conclusies van de beoordeling van de gevolgen voor het gebied en onder voorbehoud van het bepaalde in lid 4, geven de bevoegde nationale instanties slechts toestemming voor dat plan of project nadat zij de zekerheid hebben verkregen dat het de natuurlijke kenmerken van het betrokken gebied niet zal aantasten en nadat zij in voorkomend geval inspraakmogelijkheden hebben geboden.

4. Indien een plan of project, ondanks negatieve conclusies van de beoordeling van de gevolgen voor het gebied, bij ontstentenis van alternatieve oplossingen, om dwingende redenen van groot openbaar belang, met inbegrip van redenen van sociale of economische aard, toch moet worden gerealiseerd, neemt de Lid-Staat alle nodige compenserende maatregelen om te waarborgen dat de algehele samenhang van Natura 2000 bewaard blijft. De Lid-Staat stelt de Commissie op de hoogte van de genomen compenserende maatregelen.

5. Wanneer het betrokken gebied een gebied met een prioritair type natuurlijke habitat en/of een prioritaire soort is, kunnen alleen argumenten die verband houden met de menselijke gezondheid, de openbare veiligheid of met voor het milieu wezenlijke gunstige effecten dan wel, na advies van de Commissie, andere dwingende redenen van groot openbaar belang worden aangevoerd.

\subsubsection{Natura 2000-doelensystematiek}

De systematiek van het formuleren van de Natura 2000-doelen op landelijk niveau en op gebiedsniveau wordt toegelicht in het Natura 2000-doelendocument (Ministerie van Landbouw, Natuur en Voedselkwaliteit, 2006). In de volgende paragrafen wordt kort ingegaan op de filosofie, hoofdlijnen en principes die gevolgd zijn bij het formuleren van de instandhoudingsdoelen.

\subsubsection{Filosofie}

De filosofie van het Natura 2000-doelendocument bevat drie elementen: 'duidelijkheid bieden, richting geven en ruimte laten'. Er is voor gekozen om de Natura 2000-doelen - op gebiedsniveau - nader uit te laten werken in omvang, ruimte en tijd (en kwaliteit) in de beheerplannen. Dit met het argument dat op het niveau van het Natura 2000-gebied het best kan worden bepaald waar precies, met welke middelen, in welke omvang en met welk tempo de realisering van de doelen kan plaatsvinden. Om de samenhang (interne coherentie) te waarborgen tussen de instandhoudingsdoelen op verschillende schaalniveaus (Europa, Nederland en de Natura 2000-gebieden), zijn in het Natura 2000doelendocument acht hoofdlijnen aangehouden, zoals aangegeven in de volgende paragraaf.

\subsubsection{Hoofdlijnen}

De hoofddoelstelling van de Europese richtlijnen is het waarborgen van de biodiversiteit in Europa. De soorten en habitattypen die onder deze verplichting vallen, moeten op landelijk niveau in een gunstige staat van instandhouding worden gehouden of hersteld. Om dit te bereiken, zijn in het Natura 2000doelendocument de instandhoudingsdoelen op zowel landelijk niveau als op gebiedsniveau geformuleerd. Hierbij zijn bepaalde keuzes gemaakt, gebaseerd op acht hoofdlijnen (zie tekstbox). In hoofdstuk 3 wordt hier nader op ingegaan. 
De acht hoofdlijnen van het Natura 2000-doelendocument 2006

1. Maximaal aansluitend bij bestaand beleid

2. Haalbaar en betaalbaar

3. Behoud en waar nodig verbeteren

4. Hogere inzet bij groter relatief belang

5. Doen wat redelijkerwijs van Nederland verwacht kan worden

6. Anticiperend op natuurlijke dynamiek en klimaatverandering (robuust in de tijd geformuleerd)

7. Sturend voor bescherming en beheer en tevens ruimte overlatend voor de concrete invulling op gebiedsniveau

8. Passend binnen bestaande budgetten

\subsubsection{Principes}

Bij het formuleren van de Natura 2000-doelen zijn de principes 'strategisch lokaliseren' en 'balans tussen richting geven en ruimte laten' gevolgd.

\subsubsection{Proceslijnen}

Voor de formulering van de Natura 2000-doelen is vanuit twee proceslijnen gewerkt. De eerste proceslijn is gericht op de soorten en habitattypen en leidt tot doelen op landelijk niveau. De tweede proceslijn is gericht op gebieden en leidt tot doelen op gebiedsniveau. De ten behoeve van deze proceslijn uitgevoerde analyses hebben een belangrijke input geleverd ten behoeve van de toedeling van doelen aan concrete gebieden (ministerie van Landbouw, Natuur en Voedselkwaliteit, 2006) ${ }^{2}$.

Tabel 1 De door het ministerie van EZ gevolgde aanpak voor de formulering Natura 2000-doelen op landelijk niveau (proceslijn 1) en op gebiedsniveau (proceslijn 2).

\begin{tabular}{ll} 
Proceslijn 1 formulering landelijke doelen & Proceslijn 2 formulering gebiedsdoelen \\
Stap 1 definiëring (selectie) van habitattypen en soorten & Stap 1 toedeling gebieden aan Natura 2000-landschappen \\
\hline Stap 2 bepaling relatief belang van NL binnen EU & Stap 2 formulering kernopgaven per landschap \\
\hline $\begin{array}{l}\text { Stap } 3 \text { beoordeling staat van instandhouding habitattypen } \\
\text { en soorten }\end{array}$ & Stap 3 toedeling kernopgaven aan gebieden \\
\hline Stap 4 definiëring verbeteropgaven & Stap 4 inschatting haalbaarheid \\
\hline Stap 5 formulering landelijke doelen & Stap 5 inschatting zwaarte opgaven \\
\hline
\end{tabular}

In een aantal situaties wordt in het Natura 2000-doelendocument aangegeven of er sprake is van een zekere Sense of Urgency (SoU) en is ook aangegeven welke waarden ten gunste van andere waarden achteruit mogen gaan in een concreet gebied. Complementaire doelen zijn geformuleerd om de opgave te focussen op het Natura 2000-netwerk opdat een zo min mogelijke opgave wordt gelegd op het realiseren van de landelijke doelen buiten het Natura 2000-netwerk. In de volgende paragrafen worden de proceslijnen verder toegelicht.

\subsubsection{Formulering van landelijke doelen (proceslijn 1)}

\subsubsection{Definiëring (selectie) habitattypen en soorten}

De Natura 2000-doelen zoals geformuleerd in het Natura 2000-doelendocument bevatten niet alle soorten en habitattypen van de bijlagen van de Vogelrichtlijn en de Habitatrichtlijn, maar alleen die soorten en habitattypen waarvoor gebieden aangewezen zijn. Voor de Habitatrichtlijn zijn doelen geformuleerd voor de habitattypen van Annex I en soorten van Annex II, die op de Nederlandse referentielijst staan. Voor de VR zijn doelen geformuleerd voor vogelsoorten van Annex I en de geregeld voorkomende trekvogels (niet op Annex 1) conform artikel 4.2 van de Vogelrichtlijn. De habitattypen zijn geïnterpreteerd op basis van de Europese interpretatie manual. De soorten en habitattypen worden beschreven in het profielendocument (ministerie van Economische Zaken, 2014).

${ }^{2}$ Het is niet geheel duidelijk op welke analyses hier wordt gedoeld en in hoeverre deze analyses ook zijn gedocumenteerd. 


\subsubsection{Bepaling relatieve belang van NL binnen de EU}

Het relatieve belang van Nederland voor de EU is bepaald op basis van:

- Ligging van Nederland binnen het verspreidingsgebied

- Mate van voorkomen in Nederland

- Relatieve aandeel in de totale Europese oppervlakte

- Relatieve aandeel van de Europese populatie

- Relatieve aandeel van de biogeografische populatie

- Bijdrage aan de ecologische variatie

Nederland vormt ongeveer 1 procent van het grondgebied van de Europese Unie. Het relatieve belang is onderverdeeld in drie klassen:
A. zeer groot
B. groot
C. aanzienlijk

Voor habitattypen en soorten van de Habitatrichtlijn is groot belang (klasse B) gedefinieerd als een aandeel tussen 0,5 en 4 procent van het Europese totaal, een zeer groot belang als ten minste 4 procent (klasse $A$ ) daarvan en een aanzienlijk belang als het aandeel hoogstens 0,5 procent is (klasse C).

Voor broedvogels en niet-broedvogels is een iets andere indeling gehanteerd. Een groot belang is daarbij gedefinieerd als een aandeel van 1-15 procent (de ondergrens is op 1 procent gelegd overeenkomstig de gehanteerde methodiek), een zeer groot belang bij meer dan 15 procent. Voor niet-broedvogels wordt tevens aangegeven of meer dan 50 procent van de internationale populatie in Nederland verblijft.

\subsubsection{Beoordeling staat van instandhouding}

Voor de beoordeling van de staat van instandhouding van soorten en habitattypen is aangesloten bij de 'stoplichtenbenadering', ofwel de beoordelingsmatrices voor de rapportage op grond van artikel 17 van de Habitatrichtlijn (zie Bijlage 1). Deze beoordelingsmatrices zijn gebaseerd op de definitie van de staat van instandhouding uit de Habitatrichtlijn.

De beoordeling is gebaseerd op beschikbare gegevens en op best expert judgement. De beoordeling is met een groot aantal deskundigen en beheerders van de gebieden gedaan.

In het doelendocument is ook de staat van instandhouding van de vogelsoorten beoordeeld. De staat van instandhouding is echter geen vereiste vanuit de Vogelrichtlijn. Het is hier alleen gebruikt als houvast om landelijke doelen op te stellen.

\subsubsection{Formulering van landelijke instandhoudingsdoelen}

Op basis van de beoordeling van het relatief belang van NL voor de EU en van de staat van instandhouding zijn de landelijke instandhoudingsdoelen geformuleerd. Instandhoudingsdoelen zijn geformuleerd voor afzonderlijke soorten en habitattypen, maar ook voor samenhangende landschappen of systemen.

De instandhoudingsdoelen voor de habitattypen zijn gebaseerd op de best mogelijke inschatting over aanwezige oppervlaktes, aanwezige kwaliteit (structuur en functie) en huidige en toekomstige bijdrage die een gebied levert of kan leveren. Bij een ongunstige staat van instandhouding zijn de doelen in principe in termen gedefinieerd van herstel (uitbreiding verspreiding, oppervlakte en/of verbetering kwaliteit). Bij een gunstige staat van instandhouding in termen van behoud. Hierop zijn enkele uitzonderingen gemaakt, bijvoorbeeld wanneer een herstelopgave niet realistisch werd geacht.

De instandhoudingsdoelen voor de soorten van de Habitatrichtlijn zijn op een vergelijkbare wijze tot stand gekomen. Bij een ongunstige staat van instandhouding zijn de doelen in principe in termen gedefinieerd van herstel (uitbreiding verspreiding, populatiegrootte en/of verbetering omvang en kwaliteit leefgebied) en bij een gunstige staat van instandhouding in termen van behoud. Ook hier zijn enkele uitzonderingen op gemaakt. 
De landelijke doelen voor broedvogels in een gunstige staat van instandhouding gaan in principe uit van behoud van omvang (oppervlakte) en kwaliteit van het leefgebied voor het behoud van de actuele populatie in Nederland. Bij broedvogels met een ongunstige staat van instandhouding wordt doorgaans een herstelopgave geformuleerd. De mate van herstel hangt mede af van:

- De gewenste omvang voor een duurzame populatie in termen van aantal paren en aantal sleutelpopulaties.

- Internationale betekenis van de Nederlandse populatie, met name in EU-verband, zowel wat betreft aantal broedparen als wat betreft bijdrage aan de geografische spreiding.

De landelijke doelen voor niet-broedvogels met een gunstige staat van instandhouding zijn geformuleerd in termen van behoud van de omvang (oppervlakte) en de kwaliteit van het leefgebied voor het behoud van de actuele populatie in Nederland.

\subsubsection{Formulering gebiedsdoelen (proceslijn 2)}

\subsubsection{Toedeling Natura 2000-gebieden en Natura 2000-landschappen}

Op de toekenning van doelen op gebiedsniveau hanteerbaar te maken, is het Natura 2000-netwerk opgedeeld in acht zogenaamde Natura 2000-landschappen. De acht landschappen onderscheiden zich duidelijk te opzichte van elkaar wat betreft aard van de bijdrage aan het Natura 2000-netwerk en de meest relevante processen. De volgende landschappen zijn onderscheiden:

1. Noordzee

2. Duinen

3. Rivierengebied

4. Meren en Moerassen

5. Beekdalen

6. Hogere zandgronden

7. Hoogvenen

8. Heuvelland

\subsubsection{Formulering kernopgaven}

Elk van de Natura 2000-landschappen heeft in meer of mindere mate ten gevolge van de historie van de bescherming van gebieden en de aard van de ligging in het omringende landschap eigen specifieke processen en daarmee verschillende 'knoppen' waar aan gedraaid kan worden om een meer duurzame bescherming van de gebieden en een meer gunstige staat van instandhouding van de voor het landschap specifieke habitattypen en soorten te garanderen.

Voor alle landschappen zijn kernopgaven geformuleerd, uitgaande van de landelijke instandhoudingsdoelen. De kernopgaven hebben in het bijzonder betrekking op habitattypen en soorten die sterk onder druk staan en/of waarvoor Nederland van groot of van zeer groot belang is. De kernopgaven omvatten vaak meerdere soorten en habitattypen die op landschapsniveau en op gebiedsniveau om een samenhangende aanpak in het kader van inrichting en beheer vragen. Ze geven de belangrijkste behoud- en herstelopgaven per Natura 2000-landschap. De kernopgaven stellen ook prioriteiten (ook in het kader van de beheerplannen) en brengen overeenkomsten en verschillen aan tussen en binnen de gebieden.

\subsubsection{Toedeling kernopgaven aan gebieden}

De kernopgaven zijn vervolgens toebedeeld aan de Natura 2000-gebieden. Dit om de Natura 2000doelen per gebied te concretiseren en te focussen. De kernopgaven geven in feite aan welke gebieden de relatief grootste bijdrage leveren voor de realisering van de landelijke doelen. Bij de toedeling van de kernopgaven is vooral bepalend wat de actuele kwaliteit is of de mate waarin een gebied een bijdrage levert of kan leveren aan het realiseren van het landelijke doel. De toedeling van de kernopgaven is gebaseerd op een inschatting van de huidige bijdrage van het gebied aan de van toepassing zijnde doelen op landelijk niveau. Per gebied zijn in principe vier kernopgaven toebedeeld (afhankelijk van de grootte en diversiteit van het gebied). De toedeling (voor zover relevant voor de samenhang van het Natura 2000-netwerk) is gecheckt op geografische spreiding binnen de landschappen en over Nederland. 


\subsubsection{Inschatting haalbaarheid en zwaarteopgave}

Per gebied en per kernopgave zijn de huidige situatie (inclusief Sense of Urgency) en de zwaarteopgave gescoord conform een zogenaamde stoplichtenbenadering. Groen betekent dat de situatie al is bereikt of kan worden bereikt met voorgenomen of geplande maatregelen op basis van bestaand beleid. Oranje betekent dat dat de gewenste situatie (deels) is te bereiken op basis van bestaand beleid. Rood betekent dat de gewenste situatie niet te bereiken is met bestaand beleid.

Een Sense of Urgency is toegekend als binnen nu en tien jaar mogelijk een onherstelbare situatie ontstaat. De zwaarte van de opgave geeft in tijd, geld, schaal en maatschappelijk draagvlak aan hoe groot de afstand is tussen de huidige situatie en de gewenste situatie.

\subsubsection{Formulering gebiedsdoelen}

Voor alle soorten en habitattypen in de Natura 2000-database uit 2004 is een doel geformuleerd in termen van behoud of herstel. Voor soorten en habitattypen die vallen onder de kernopgaven zijn doorgaans doelen geformuleerd in termen van herstel (uitbreiding en/of verbetering). Daarbij is nadrukkelijk rekening gehouden met de noodzakelijke inspanningen om de gewenste situatie te bereiken. Op een gebied is een hoger doel neergelegd als het gebied een grote potentie heeft voor bepaalde soorten en habitattypen en er relatief weinig inspanning vereist is om dat hogere doel te halen. Op een gebied met dezelfde potentie, maar waar voor de realisering daarvan een grotere inspanning nodig is, is een lager doel neergelegd. Concreet betekent dit dat voor een soort of habitattype de relatief grootste bijdrage komt van een gebied waar nu de ecologische vereisten het best op orde zijn, de huidige relatieve bijdrage groot is of dat de potentiële relatieve bijdrage groot is en op termijn de ecologische vereisten relatief makkelijk op orde te brengen zijn.

De doelen voor vogelsoorten zijn uitgedrukt in concrete aantallen (populatiegrootte) als proxi voor de draagkracht van omvang en kwaliteit leefgebied. Voor de habitattypen en voor de meeste overige soorten was dat niet mogelijk door gebrek aan gegevens en kennis. Bij vogels zijn de doelen gebaseerd op de relatieve bijdrage van gebieden in de internationale en nationale populatie en op informatie over de trends in aantallen (populatiegrootte) in de gebieden. De doelen voor broedvogels zijn geformuleerd met een draagkracht voor een populatie van een aantal paren. In de toelichting van het doel wordt aangegeven of een gebied voldoende draagkracht heeft voor een sleutelpopulatie of dat een gebied een bijdrage levert aan een sleutelpopulatie. Bij de doelen voor de niet-broedvogels wordt aangegeven hoeveel vogels dit leefgebied gemiddeld huisvest (ook een draagkrachtschatting). Zo mogelijk is dit aantal berekend uit maandelijkse tellingen per seizoen, gemiddeld over de periode 1999-2000 tot en met 2003-2004 of, bij een ongunstige staat van instandhouding, over een nader gespecificeerde periode. Als er geen maandelijkse tellingen beschikbaar waren, is gebruikgemaakt van januari-tellingen of seizoenmaxima. Bij niet-broedvogels wordt onderscheid gemaakt tussen slaapplaats- en foerageerfuncties. Dit wordt aangeduid in de toelichting op het doel. Bij ganzen, die in grote getalen buiten de Natura 2000-gebieden foerageren, wordt in de gebieden die zowel een slaapplaatsfunctie als foerageerfunctie hebben met twee getallen in de doelen gewerkt. De getallen voor de slaapplaatsfunctie zijn in de regel ook gebaseerd op tellingen uit de periode 1999/2000 en $2003 / 2004$.

\subsubsection{Complementaire doelen}

Voor de meeste habitattypen en soorten kan het landelijke doel gerealiseerd worden met de gebiedsdoelen, zoals gebaseerd op de aanmeldingen bij de Europese Commissie. Voor een aantal soorten en habitattypen dragen de voorkomens buiten de Natura 2000-gebieden bij aan de realisatie van een landelijk doel. Complementaire doelen zijn geformuleerd (op basis van artikel 10a, lid 3 van de Natuurbeschermingswet) om de opgave te focussen op het Natura 2000-netwerk opdat een zo min mogelijke opgave wordt gelegd op het realiseren van de landelijke doelen buiten het Natura 2000netwerk.

Voor de formulering van deze complementaire doelen zijn twee categorieën onderscheiden:

- Categorie 1: voor soorten en habitattypen met een ongunstige staat van instandhouding én voor soorten en habitattypen met een lage landelijke dekking en/of onvoldoende geografische spreiding, zijn Habitatrichtlijndoelen toegekend aan Vogelrichtlijngebieden én Vogelrichtlijndoelen aan Habitatrichtlijngebieden. 
- Categorie 2: voor soorten en habitattypen met een zeer ongunstige staat van instandhouding waarvoor in concrete gebieden goede kansen aanwezig zijn voor de vestiging van een populatie of de ontwikkeling van een habitattype, zijn complementaire doelen geformuleerd. Deze doelen zijn alleen toegekend aan Habitatrichtlijngebieden en betreffen ontwikkeldoelen.

Complementaire doelen zijn in aanwijzingsbesluiten opgenomen, maar zijn niet aangemeld aan de EC. In Standard Data Forms worden deze soorten en habitattypen niet vermeld.

\subsubsection{Ten gunste van formulering}

In een beperkt aantal situaties, in het Rivierengebied en de Duinen, is gewerkt met een 'ten gunste van'-formulering. Daarbij is aangegeven dat voor een bepaalde soort of habitattypen enige afname is toegestaan ten gunste van andere soorten en habitattypen die sterk onder druk staan en waarvoor in het concrete gebied doelen in termen van uitbreiding omvang leefgebied of uitbreiding oppervlakte zijn geformuleerd.

\subsection{Aanwijzingsbesluiten}

\subsubsection{Functie}

De aanwijzingsbesluiten geven - naast de omvang en begrenzing van het Natura 2000-gebied duidelijkheid over de instandhoudingsdoelstellingen die gelden voor een Natura 2000-gebied. Dit zorgt voor richting en houvast bij het opstellen van beheerplannen en de toetsing bij vergunningverlening. De aanwijzingsbesluiten geven met het vaststellen van de instandhoudingsdoelstellingen een eerste stap naar meer duidelijkheid over de mogelijkheden van een activiteit in of rondom een Natura 2000gebied (Programmadirectie Natura 2000, 2011b).

\subsubsection{Proces}

De aanwijzingsbesluiten voor de Natura 2000-gebieden worden opgesteld door het ministerie van Economische Zaken (EZ). Bij een definitief aanwijzingsbesluit komt een Vogel- en/of Habitatrichtlijngebied onder de wettelijke bescherming van de Natuurbeschermingswet 1998. Het aanwijzingsbesluit somt op voor welke habitattypen en/of soorten een gebied wordt aangewezen. Een belangrijk onderdeel van de besluiten zijn de instandhoudingsdoelstellingen. Bij elk ontwerpaanwijzingsbesluit vindt een inspraakprocedure plaats op grond van de Algemene wet bestuursrecht. Het (definitieve) aanwijzingsbesluit volgt na afloop van de openbare procedure. Belanghebbenden kunnen, na een zienswijze ingediend te hebben, in beroep gaan bij de Raad van State als ze het niet eens zijn met het (definitieve) aanwijzingsbesluit (Programmadirectie Natura 2000, 2014). Na uitspraak van de Raad van State en eventuele wijzigingen naar aanleiding daarvan wordt het besluit onherroepelijk.

In 2000 is de aanwijzing van de Vogelrichtlijngebieden voor het belangrijkste deel afgerond en in 2004 plaatste de Europese Commissie de door Nederland in 2003 aangemelde Habitatrichtlijngebieden op een communautaire lijst. In totaal gaat het om ca. 160 Natura 2000-gebieden (Programmadirectie Natura 2000, 2011b). De mariene gebieden in de EEZ zijn in ontwerp aangewezen; na definitieve aanwijzing komt er een Vogelrichtlijngebied bij in de database. Voor status aanwijzingsbesluiten, zie Figuur 2. 


\section{Status aanwijzingsbesluiten september 2015}

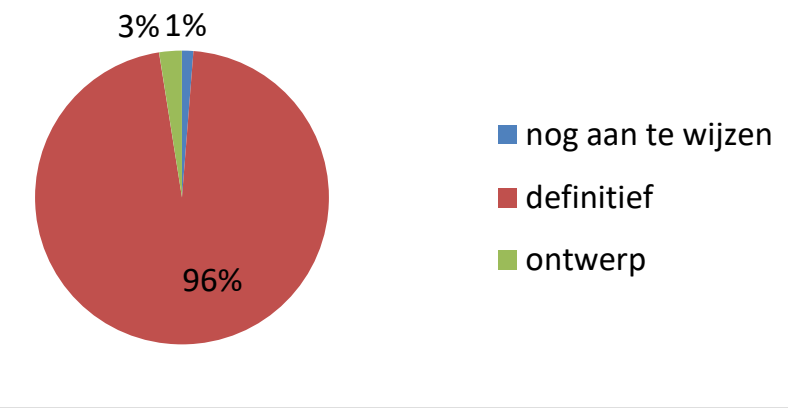

Figuur 2 Status aanwijzingsbes/uiten, peildatum september 2015.

\subsubsection{Inhoud}

De aanwijzingsbesluiten bestaan uit de formele tekst van het besluit, een Nota van toelichting en één of meer kaarten.

\section{Formele tekst besluit}

Het besluit is in feite de juridische basis voor de aanwijzing van het gebied onder de Vogel- en/of Habitatrichtlijn. Elk besluit bestaat uit een aantal artikelen. In het geval dat sprake is van de aanwijzing van een Habitatrichtlijngebied geeft het eerste artikel van het besluit de naam van het gebied (artikel 1, lid 1) en wordt vervolgens opgesomd voor welke habitattypen en soorten het gebied is aangewezen in het kader van de Habitatrichtlijn. Artikel 2 (artikel 1 indien uitsluitend Vogelrichtlijngebied) vermeldt voor welke vogelsoorten het gebied onder de Vogelrichtlijn is aangewezen. In het volgende artikel wordt de naam van het Natura 2000-gebied genoemd en wordt aangegeven dat het besluit verder bestaat uit een Nota van toelichting (inclusief bijlagen) en een of meer kaarten. Dit artikel verwijst verder naar de instandhoudingsdoelstellingen die zijn opgenomen in hoofdstuk 5 van de Nota van toelichting. Ten slotte regelt het laatste artikel de publicatie en de inwerkingtreding van het besluit. Dat laatste gebeurt na vaststelling van het (definitieve) aanwijzingsbesluit waarbij zo veel mogelijk rekening zal worden gehouden met de in het kader van de inspraakprocedure ingediende zienswijzen (Programmadirectie Natura 2000, 2014).

\section{Nota van toelichting}

In hoofdstuk 1 van de Nota van toelichting wordt ingegaan op de relatie tussen de Nota van toelichting en het besluit. Ook wordt de opbouw van de Nota besproken. In hoofdstuk 2 worden de aanwijzingen onder de Habitat- en/of Vogelrichtlijn toegelicht. Ook wordt een relatie gelegd met het Natura 2000-doelendocument 2006 en het Natura 2000-profielendocument 2008. In hoofdstuk 3 worden de landschappelijke context en de natuurlijke kenmerken en ook de begrenzing en het oppervlakte van het gebied beknopt beschreven. Naast de Natura 2000-waarden omvat het gebied ook natuurwaarden die integraal onderdeel uitmaken van de ecosystemen waartoe de aangewezen (leefgebieden van) soorten en habitattypen behoren, alsmede natuurwaarden waarvan het behoud een belangrijke bijdrage levert aan het behalen van de landelijke gunstige staat van instandhouding (Programmadirectie Natura 2000, 2014). In hoofdstuk 4 worden de Natura 2000-waarden waarvoor het gebied is aangewezen, weergegeven. Wijzigingen in soorten en habitattypen ten opzichte van de aanmelding als Habitatrichtlijngebied en wijzigingen in vogelsoorten ten opzichte van eerdere aanwijzing als Vogelrichtlijngebied (Bijlage B) worden hier inzichtelijk gemaakt. Een toelichting wordt ook gegeven op de selectiecriteria van de Habitatrichtlijngebieden. Indien (ook) sprake is van een Vogelrichtlijngebied, worden de selectiecriteria van de Vogelrichtlijngebieden als appendix toegevoegd. In hoofdstuk 5 worden de algemene doelen en de instandhoudingsdoelen beschreven. In Bijlage B wordt inzichtelijke gemaakt hoe de landelijke doelstelling is vertaald naar Natura 2000-gebieden. Per Natura 2000-waarde wordt een overzicht gegeven van alle gebieden en de daarvoor van toepassing zijnde doelen (behoud- of herstelopgave). 


\subsection{Beheerplannen}

\subsubsection{Functie}

In het beheerplan worden de instandhoudingsdoelstellingen vertaald naar concrete uitvoeringsmaatregelen, uitgezet in de tijd en naar specifieke locaties. Daarbij wordt rekening gehouden met het bestaand gebruik en gestreefd naar balans tussen ecologie en economie (Programmadirectie Natura 2000, 2011b). In aanvulling op het aanwijzingsbesluit biedt het handvatten voor het toepassen van het afwegingskader voor de vergunningverlening in het kader van de Natuurbeschermingswet 1998. Met het beheerplan wordt duidelijkheid geboden aan beheerders, gebruikers en belanghebbenden ten aanzien van de vraag welke activiteiten in het Natura 2000gebied in geen geval zijn toegestaan zonder dat deze eerst getoetst zijn aan artikel 19j van de Natuurbeschermingswet 1998 (Habitattoets). Maar ook welke activiteiten op wettelijke gronden geen vergunning behoeven, omdat ze de instandhoudingsdoelstellingen in het gebied niet in gevaar brengen. Het beheerplan is ook hét instrument waarmee invulling wordt gegeven aan de wettelijke vereiste om bij de keuze en vormgeving van maatregelen rekening te houden met economische, sociale en culturele belangen (ministerie van Landbouw Natuur en Voedselkwaliteit, 2005).

\subsubsection{Proces}

Op basis van de in de aanwijzingsbesluiten vastgelegde instandhoudingsdoelstellingen en gebiedsbegrenzingen, moeten op basis van de Natuurbeschermingswet 1998 binnen drie jaar na definitieve aanwijzing beheerplannen worden opgesteld. De ontwikkeling van de beheerplannen is een gezamenlijke verantwoordelijkheid voor de bevoegde instanties (LNV, Verkeer en Waterstaat, Defensie, provincies) en gemeenten, waterschappen, natuurbeschermingsorganisaties, maatschappelijke organisaties, ondernemers, terreinbeheerders, gebruikers, eigenaren en andere belanghebbenden. De bevoegde instanties hebben met elkaar duidelijke afspraken gemaakt over het opstellen en vaststellen van deze plannen. Per Natura 2000-gebied is één bevoegd gezag aangewezen, de zogenoemde voortouwnemer (provincies of Rijk). De voortouwnemer neemt het initiatief om o.a. grondeigenaren, gebruikers, besturen van waterschappen, gemeenten en andere belanghebbenden tijdig te betrekken (Programmadirectie Natura 2000, 2011b). Zie Figuur 3 voor de status van het beheerplanproces, peildatum september 2015.

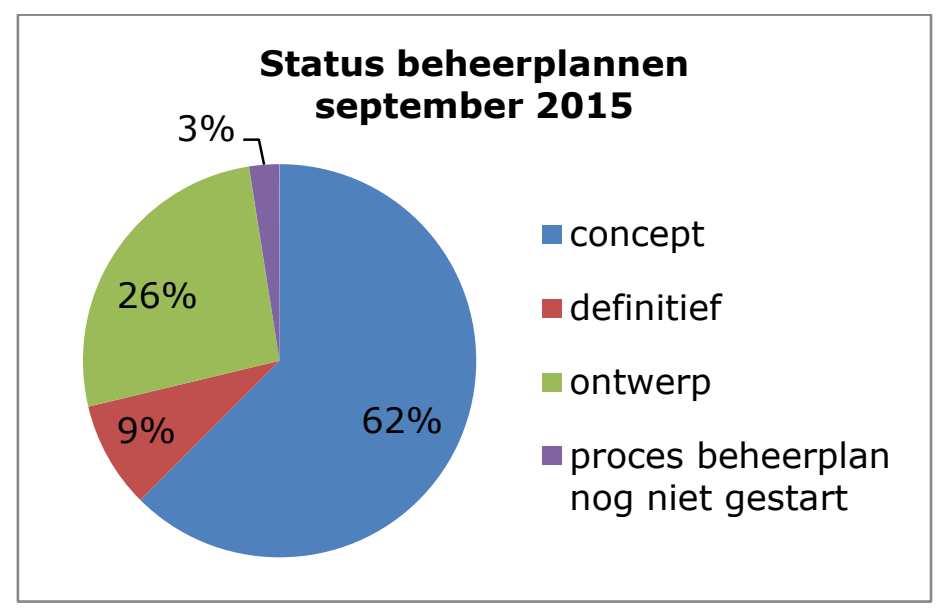

Figuur 3 Status beheerplannen, peildatum september 2015.

\subsubsection{Inhoud}

In de Handleiding Beheerplannen Natura 2000-gebieden (ministerie van Landbouw, Natuur en Voedselkwaliteit, 2005) is een Programma van Eisen opgenomen met procedurele en inhoudelijke eisen aan de beheerplannen. Deze eisen zijn vervolgens verwerkt en gespecificeerd in de Checklist Beheerplannen Natura 2000 (Programmabureau Natura 2000, 2009). Deze checklist is vooral van 
belang tijdens het proces als leidraad bij het opstellen van beheerplannen en als basis voor gesprekken tussen bevoegde gezagen en beheerplanopstellers. Het doel is het opleveren van volledige en juridisch houdbare beheerplannen, die zijn opgesteld met en gedragen door alle betrokken partijen uit de streek.

Inhoudelijke checkpunten $\left(9 \mathrm{t} / \mathrm{m}^{3} 0^{3}\right.$ ) van de beheerplannen betreffen:

1. Instandhoudingsdoelen (beschrijving natuurwaarden en nadere uitwerking in omvang, ruimte, tijd en kwaliteit)

2. Bestaand gebruik en toetsing aan instandhoudingsdoelen

3. Maatregelen

4. Bestaand beleid en regelgeving

5. Monitoring

6. Stikstof (PAS)

7. Water (KRW)

8. Sociaaleconomische aspecten

\subsubsection{Instandhoudingsdoelen}

De instandhoudingsdoelen uit het aanwijzingsbesluit vormen de basis voor het beheerplan. In de Nota van toelichting van de aanwijzingsbesluiten worden de natuurwaarden en de instandhoudingsdoelen toegelicht (zie paragraaf 2.2). In het beheerplan dienen de instandhoudingsdoelen nader uitgewerkt te worden in omvang, ruimte en tijd (en kwaliteit). De algemene doelen uit het aanwijzingsbesluit hoeven niet terug te komen in het beheerplan.

Alle instandhoudingsdoelen uit het aanwijzingsbesluit moeten in het beheerplan opgenomen worden (checkpunt 9). Ook de kernopgaven uit het Natura 2000-doelendocument moeten worden overgenomen in de beheerplannen (checkpunt 10). De beschrijving van de natuurwaarden moet ecologisch worden onderbouwd door middel van een landschapsecologische systeemanalyse conform het Werkkader Landschapsecologische Systeemanalyse, waarbij de koppeling gelegd wordt tussen biotiek en abiotiek (checkpunt 11). Andere natuurwaarden dan de instandhoudingsdoelen van de Vogelrichtlijn en de Habitatrichtlijn mogen vermeld worden. Het ministerie van EZ heeft besloten om de 'oude doelen' van de beschermde natuurmonumenten te doen vervallen. Indien voortouwnemers landschappelijke en cultuurhistorische of andere natuurdoelen aan het beheerplan willen toevoegen dan kan dat, mits de doelen en daarvoor benodigde maatregelen en budgetten apart worden weergegeven.

Vanwege handhaving, toetsing en vergunningverlening wordt een volledige beschrijving gevraagd van de natuurwaarden (kwantiteit en kwaliteit), inclusief de ecologische aspecten die hieraan ten grondslag liggen. Van de voortouwnemers/opsteller van de beheerplannen wordt verwacht dat er actuele en zo mogelijk historische informatie wordt opgenomen in de beheerplannen - afhankelijk van de beschikbare inventarisaties - over:

- Het voorkomen ofwel de verspreiding van soorten en habitattypen binnen het gebied op kaart (checkpunt 15);

- De populatieomvang c.q. de populatiegrootte van soorten (checkpunt 14);

- De omvang en de kwaliteit van habitattypen en leefgebieden van soorten (checkpunt 12 en 13). Het doel is om veranderingen binnen een beheerplanperiode van zes jaar te kunnen vaststellen. Gevraagd wordt naar de status en de trend.

De precieze bijdrage aan de landelijke uitbreidings- en verbeteropgaven is bewust niet vooraf bepaald, omdat op het niveau van de beheerplannen het best kan worden bepaald waar in welke omvang en met welk tempo de realisering van de doelen kan plaatsvinden. Wel dient men rekening te houden met de relatieve bijdrage die ieder gebied kan leveren, zodat op lange termijn een gunstige staat van instandhouding op landelijk niveau wordt geborgd (checkpunt 16). De kwaliteitsdoelen moeten concreet en toetsbaar zijn uitgewerkt met de elementen uit het profielendocument (checkpunt $17 \mathrm{t} / \mathrm{m}$ 21). Bij uitbreidingsdoelstellingen moet duidelijk worden aangegeven waar uitbreiding zal plaatsvinden en van welke kwaliteit de doelhectares zullen zijn (checkpunt 22).

\footnotetext{
$31 \mathrm{t} / \mathrm{m} 8$ betreffen procesmatige checkpunten, hier niet relevant.
} 


\subsubsection{Bestaand gebruik en toetsing aan instandhoudingsdoelstellingen}

Het beheerplan geeft duidelijkheid over welke activiteiten geen negatieve effecten hebben op de instandhoudingsdoelstellingen en daarmee (indien de nodige voorwaarden) vergunningvrij zijn toegestaan in en rondom het Natura 2000-gebieden. Twee belangrijke aspecten als het gaat om bestaand gebruik zijn: een inventarisatie van bestaand gebruik in en om het Natura 2000-gebied en een ecologische toetsing van het bestaande gebruik met de instandhoudingsdoelstellingen (checkpunt 23).

\subsubsection{Maatregelen}

Maatregelen moeten zo veel mogelijk SMART geformuleerd worden (checkpunt 25). Aangegeven moet worden wanneer de maatregelen genomen worden ( $1^{\mathrm{e}}$ beheerplanperiode of een volgende). Sense of Urgency-maatregelen moeten de eerste beheerplanperiode genomen worden. Duidelijk moet zijn wat het grootste knelpunt is en wat de belangrijkste maatregelen zijn om de doelen te realiseren. De maatregelen moeten haalbaar en betaalbaar zijn (checkpunt 26). De Natura 2000-gebieden met een SoU hebben hoogste prioriteit (checkpunt 24).

\subsubsection{Bestaand beleid en wet- en regelgeving}

Onderscheid wordt gemaakt tussen de relatie van het beheerplan met bestaande (beleids)plannen en wet- en regelgeving, bijvoorbeeld de Stroomgebiedsplannen (KRW) die bijdragen aan de realisatie van de instandhoudingsdoelstellingen (checkpunt 27) en (vice versa) de doorwerking van het beheerplan in andere relevante (beleids)plannen en wet- en regelgeving, bijvoorbeeld de Stroomgebiedsplannen (checkpunt 28).

\subsubsection{Monitoring}

Monitoring is vereist van de ontwikkelingen van de veranderingen in de natuur(waarden) in het gebied (bv. voortgang doelbereik) en het beheerplanproces (bv. voortgang uitvoering maatregelen en effecten van maatregelen). Er is een Programma van Eisen Gebiedsgerichte monitoring opgesteld. Verwacht wordt dat hier bij het opstellen van het beheerplan gebruik van gemaakt wordt voor de monitoringparagraaf (checkpunt 29 en 30).

\subsubsection{Stikstof (PAS)}

De problemen met stikstof worden geadresseerd in de Programmatische Aanpak Stikstof (PAS). De doelen van dit programma zijn tweeledig, te weten de achteruitgang van biodiversiteit te stoppen én economische ontwikkeling mogelijk te maken. In de beheerplannen moeten de PAS-maatregelen duidelijk worden vermeld en onderbouwd (checkpunt 31 t/m 34).

\subsubsection{Water (KRW)}

Door de programmadirectie Natura 2000 is een Strategie Water en Natuur 2000 opgesteld, waarmee de waterparagraaf in de Natura 2000-beheerplannen en de Natura 2000-paragraaf in de stroomgebiedsbeheerplannen kan worden opgesteld. Voor watermaatregelen is de Kaderrichtlijn Water instrumenteel van groot belang. In de Natura 2000-beheerplannen moeten de vereiste watercondities voor het behalen van de instandhoudingsdoelen concreet en werkbaar zijn opgesomd. Ook de benodigde maatregelen om die condities te bereiken moeten zijn vermeld (checkpunt $35 \mathrm{t} / \mathrm{m} \mathrm{38}$ ).

\subsubsection{Sociaaleconomische aspecten}

Een beheerplan heeft twee functies die rekening moeten houden met de sociaaleconomische gevolgen, te weten: inzicht geven in het benodigde maatregelenpakket om de doelen te behalen en een toetsingskader voor de vergunningverlening (inclusief bestaand gebruik). De financiële consequenties van de maatregelen en de sociaaleconomische consequenties betreffende huidige en toekomstige activiteiten dienen duidelijk beschreven te worden (checkpunt 39 en 40). 


\subsection{Rapportages aan de Europese Commissie}

\subsubsection{VR artikel 12-rapportage}

\subsubsection{Annex 2 VR-soorten}

Het rapportageformat voor de Vogelrichtlijnrapportage artikel 12 Annex 2 (Europese Commissie, 2011a; Europese Commissie, 2011b) schrijft voor dat er gerapporteerd wordt per vogelsoort over:

- de status en trends (korte en lange termijn) in de populatieomvang (population),

- de status en trends (korte en lange termijn) in het verspreidingsgebied (range),

- de drukfactoren en bedreigingen (main pressures and threats) en

- de instandhoudingsmaatregelen (conservation measures).

Er wordt - in tegenstelling tot de HR-rapportage - niet gevraagd om een beoordeling uit te voeren van de staat van instandhouding (conservation status) van vogelsoorten.

\subsubsection{HR artikel 17-rapportage}

\subsubsection{Annex B HR-soorten}

Het rapportageformat voor de Habitatrichtlijnrapportage artikel 17 Annex B (Europese Commissie, 2011c, Europese Commissie, 2011d) schrijft voor dat er gerapporteerd wordt per soort (Annex II, IV en $\mathrm{V}$ ) over:

- de status en trend (korte en lange termijn) in het verspreidingsgebied (range),

- de status en trend (korte en lange termijn) in de populatieomvang (population),

- het oppervlak (inclusief de trend) en de kwaliteit van het leefgebied van de HR-soort (habitat for the species),

- de drukfactoren en bedreigingen (main pressures and threats) en

- de instandhoudingsmaatregelen (conservation measures).

Op basis van deze informatie dient een oordeel geveld te worden over de "staat van instandhouding" (conservation status) van de soorten conform de voorschriften van de EC (zie Bijlage 1).

\subsubsection{Annex D habitattypen}

Het rapportageformat voor de Habitatrichtlijnrapportage artikel 17 Annex B (Europese Commissie, 2011c, Europese Commissie, 2011d) schrijft voor dat er gerapporteerd wordt per habitattype

(Annex I) over:

- de status en trend in het verspreidingsgebied (range),

- de status en trend in het oppervlak (area),

- de structuur en functie inclusief typische soorten (structure and function including typical species) van het habitattype,

- de drukfactoren,

- de bedreigingen (main pressures and threats) en

- de instandhoudingsmaatregelen (conservation measures).

Op basis van deze informatie dient een oordeel geveld te worden over de "staat van instandhouding" (conservation status) van de habitattypen conform de voorschriften van de EC (zie Bijlage 1).

\subsubsection{Referentiewaarden voor een gunstige verspreiding, populatiegrootte of oppervlakte van soorten en habitattypen}

Ten behoeve van de beoordeling van de staat van instandhouding van habitattypen en HR-soorten wordt ook om referentiewaarden (Favourable Reference Values - FRVs) gevraagd voor een gunstige verspreiding en oppervlakte van habitattypen en een gunstige verspreiding en populatiegrootte van HR-soorten. Dit zijn de drempelwaarden voor een gunstige staat van instandhouding. Deze zijn voor Nederland inmiddels vastgesteld (Bijlsma et al., 2014; Ottburg en Van Swaaij, 2014), maar nog niet gerapporteerd aan de Europese Commissie. 


\subsubsection{Standard Data Forms Natura 2000-gebieden}

\subsubsection{Hoofdstuk 3.1 habitatypen}

Het Standaard Gegevensformulier Natura 2000 (hoofdstuk 3.1) schrijft voor per Natura 2000-gebied te rapporteren over het relatieve oppervlakte van het habitattype ten opzichte van het landelijke oppervlak, de representativiteit en de behoudsstatus (bestaande uit de volgende aspecten: structuur, functie en herstelmogelijkheid) van het habitattype. Op basis van deze informatie dient een algemene beoordeling uitgevoerd te worden van de betekenis van het Natura 2000-gebied voor de instandhouding van dat habitattype.

\subsubsection{Hoofdstuk 3.2 HR- en VR-soorten}

Het Standaard Gegevensformulier Natura 2000 (hoofdstuk 3.2) schrijft voor per Natura 2000-gebied te rapporteren over de relatieve populatieomvang van een soort ten opzichte van de landelijke populatieomvang, de isolatie en de behoudsstatus (bestaande uit de volgende aspecten: leefgebied en herstelmogelijkheid) van de soort. Op basis van deze informatie dient een algemene beoordeling uitgevoerd te worden van het belang van het Natura 2000-gebied voor de instandhouding van de betreffende soort.

\subsubsection{Maatlatten en drempelwaarden}

Ten behoeve van de beoordeling van het relatieve belang van Natura 2000-gebieden voor de instandhouding van habitattypen en HR- en VR-soorten zijn voor Nederland maatlatten en drempelwaarden ontwikkeld (Janssen et al., 2014; Ottburg en Janssen, 2014 en Van Kleunen et al., 2014). 


\section{Deel I Natura 2000-doelensystematiek}

\subsection{Aanleiding en vraagstelling}

Onder de Natura 2000-doelensystematiek wordt verstaan 'de systematiek voor de formulering van de Natura 2000-doelen op landelijk niveau en op gebiedsniveau' (ministerie van Landbouw, Natuur en Voedselkwaliteit, 2006). De door Nederland gevolgde systematiek wordt door het ministerie van EZ toegelicht in het Natura 2000-doelendocument en wordt ook kort beschreven in paragraaf 2.1 van dit rapport.

De onderzoeksvragen zijn:

1. Welke voorwaarden (criteria) worden er gesteld door de Europese Commissie en Rijk aan de formulering van de Natura 2000-doelen en met welke motivatie?

2. Voldoet de formulering van de Natura 2000-doelen in respectievelijk het Natura 2000doelendocument, de aanwijzingsbesluiten en de beheerplannen van de Natura 2000-gebieden ook aan deze voorwaarden, ofwel hoe is hier invulling aan gegeven door het Rijk en voortouwnemers?

3. Wat zijn de mogelijke achterliggende oorzaken van het wel/niet voldoen aan deze voorwaarden?

4. Welke consequenties heeft dit voor de realisatie van de Natura 2000-doelen en daarmee samenhangend de doelmatigheid en doeltreffendheid van het Natura 2000-beleid?

De laatste twee vragen zijn lastig te beantwoorden, aangezien er factoren zijn - los van de Natura 2000-doelensystematiek - die van invloed zijn op de realisatie van de instandhoudingsdoelen, zoals politiek-bestuurlijke factoren. Daarom is een terugkoppeling wenselijk, zo niet noodzakelijk, met de actoren die een belangrijke rol spelen in toepassing van de Natura 2000-doelensystematiek, waaronder de voortouwnemers van de Natura 2000-gebieden.

In de Rijksnatuurvisie 2014 is de huidige visie op het natuurbeleid beschreven vanuit een bredere context dan de Vogelrichtlijn en Habitatrichtlijn, maar mogelijk wel met gevolgen voor de implementatie van de Vogelrichtlijn en Habitatrichtlijn in de toekomst. Vandaar dat deze visie ook bij dit onderzoek wordt meegenomen.

\subsection{Aanpak}

\subsubsection{Toetsingskader}

Een toetsingskader is opgesteld, gebaseerd op:

1. de voorschriften van de Europese Commissie,

2. het Natura 2000-doelendocument (ministerie van Landbouw, Natuur en Voedselkwaliteit, 2006) en

3. de Rijksnatuurvisie 2014 (ministerie van Economische Zaken, 2014a).

De voorschriften van de Europese Commissie betreffen de Vogelrichtlijn (Richtlijn 79/409/EEG) en de Habitatrichtlijn (Richtlijn 92/43/EEG), de rapportageformats en -handleidingen (Europese Commissie, 2011a; Europese Commissie, 2011b; Europese Commissie, 2011c; Europese Commissie, 2011d; Europese Commissie, 2011e) en de notitie van de Europese Commissie over de formulering van instandhoudingsdoelen (Europese Commissie, 2012). 
Tabel 2 Toetsingskader Natura 2000-doelensystematiek. De toetsingscriteria zijn hier kort beschreven in eigen bewoording (deels vertaald uit het Engels) en worden bij de bespreking van de resultaten in paragraaf 3.3 nader toegelicht. Schuingedrukt zijn de principes uit het Natura 2000 doelendocument (zie paragraaf 2.1.2.3).

\begin{tabular}{|c|c|c|c|c|}
\hline $\begin{array}{l}\text { Toetsings- } \\
\text { criteria }\end{array}$ & Beschrijving & $\begin{array}{l}\text { Voorschriften } \\
\text { Europese } \\
\text { Commissie }\end{array}$ & $\begin{array}{l}\text { Natura 2000- } \\
\text { doelendocument } 2006\end{array}$ & $\begin{array}{l}\text { Rijksnatuurvisie } \\
2014\end{array}$ \\
\hline Prioritering & $\begin{array}{l}\text { Prioriteiten ten aanzien van } \\
\text { soorten en habitattypen } \\
\text { afhankelijk van relatief belang en } \\
\text { de urgentie voor het nemen van } \\
\text { maatregelen gezien drukfactoren } \\
\text { en bedreigingen }\end{array}$ & Priorities & $\begin{array}{l}\text { Behoud waar nodig } \\
\text { verbeteren } \\
\text { Hogere inzet bij groter } \\
\text { relatief belang } \\
\text { Doen wat redelijkerwijs } \\
\text { van Nederland verwacht } \\
\text { kan worden }\end{array}$ & \\
\hline Specifiek & $\begin{array}{l}\text { Doelen t.a.v. specifieke soorten en } \\
\text { habitattypen met duidelijk } \\
\text { gedefinieerde condities waaraan } \\
\text { voldaan moet worden om } \\
\text { desbetreffende doelen te bereiken }\end{array}$ & Specific & & \\
\hline Meetbaar & $\begin{array}{l}\text { Monitoring, beoordeling en } \\
\text { rapportage mogelijk makend }\end{array}$ & Measurable & $\begin{array}{l}\text { Sturend voor } \\
\text { bescherming en beheer }\end{array}$ & \\
\hline Tijdgebonden & $\begin{array}{l}\text { Verbonden aan een bepaalde } \\
\text { termijn }\end{array}$ & & $\begin{array}{l}\text { Uitwerking in omvang, } \\
\text { tijd en ruimte in } \\
\text { beheerplannen }\end{array}$ & \\
\hline Consistent & $\begin{array}{l}\text { Op een vergelijkbare wijze voor } \\
\text { specifieke soorten en habitattypen } \\
\text { en daarvoor aangewezen Nature } \\
2000 \text {-gebieden }\end{array}$ & Consistent & & \\
\hline Alomvattend & $\begin{array}{l}\text { Alle kenmerken bevattend die } \\
\text { nodig zijn om de status van een } \\
\text { soort en habitattype te beoordelen } \\
\text { als gunstig of ongunstig }\end{array}$ & Comprehensive & & \\
\hline Robuust & $\begin{array}{l}\text { Bestand tegen toekomstige } \\
\text { ontwikkelingen }\end{array}$ & & $\begin{array}{l}\text { Anticiperend op } \\
\text { natuurlijke dynamiek en } \\
\text { klimaatverandering }\end{array}$ & $\begin{array}{l}\text { Robuuste en } \\
\text { veelzijdige natuur } \\
\text { Toekomstbestendige } \\
\text { natuur }\end{array}$ \\
\hline Flexibel & $\begin{array}{l}\text { Ruimte latend voor uitwerking op } \\
\text { regionaal en/of gebiedsniveau }\end{array}$ & & $\begin{array}{l}\text { Ruimte overlatend voor } \\
\text { de concrete invulling op } \\
\text { gebiedsniveau } \\
\text { Balans tussen sturen en } \\
\text { ruimte laten }\end{array}$ & $\begin{array}{l}\text { Flexibele aanpak bij } \\
\text { het behalen van } \\
\text { doelen van de EU- } \\
\text { richtlijn }\end{array}$ \\
\hline
\end{tabular}


Onderzocht is welke voorwaarden door de Europese Commissie en het Rijk met welke motivatie aan de formulering van de Natura 2000-doelen gesteld worden in de genoemde documenten en op welke wijze hier invulling aan is gegeven in achtereenvolgens het Natura 2000-doelendocument, de aanwijzingsbesluiten en de beheerplannen. In Tabel 2 is het toetsingskader samengevat. In paragraaf 3.3. wordt hier dieper op ingegaan.

\subsubsection{Evaluatie op basis van beheerplannen}

\subsubsection{Selectie beheerplannen}

Voor dit onderzoek zijn in totaal 31 beheerplannen van Natura 2000-gebieden doorgenomen. Deze beheerplannen zijn geselecteerd op basis van de status (concept, ontwerp, definitief) van het beheerplan ten tijde van het onderzoek (september 2015), het Natura 2000-landschapstype, de voortouwnemer en de richtlijnen waaronder het gebied valt. Er is gekozen om alleen gebieden waarvan een ontwerp of definitief beheerplan bekend was mee te nemen in de verdere selectieprocedure, omdat beheerplannen in conceptfase nog incompleet kunnen zijn en inhoudelijk nog veel kunnen veranderen.

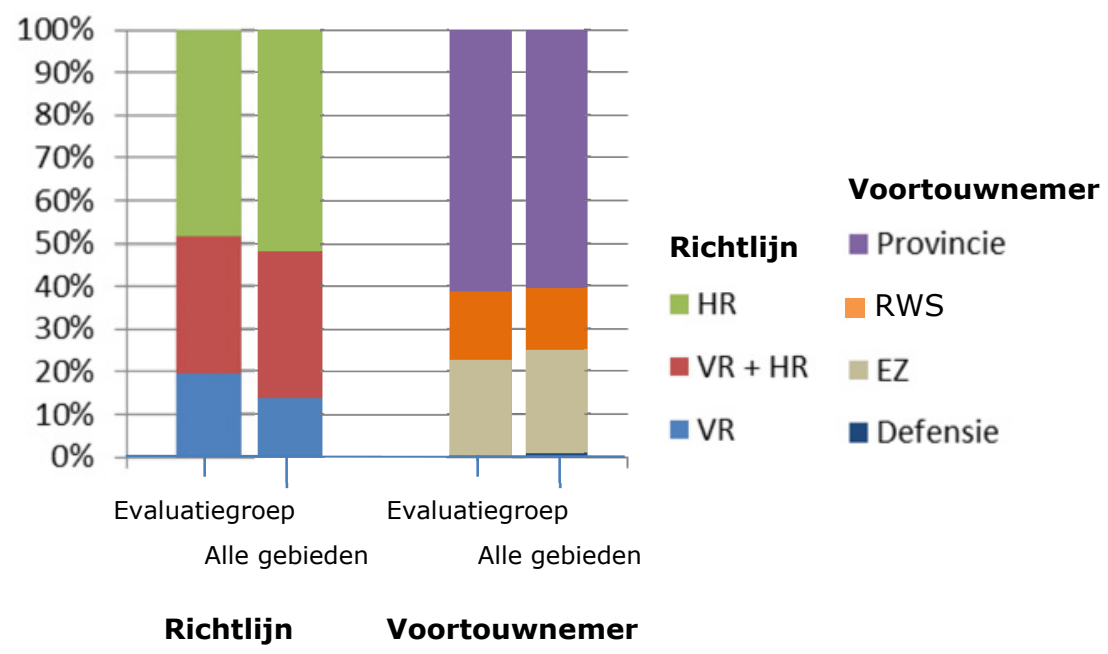

Figuur $4 \quad$ Verdeling van de Natura 2000-gebieden met een bepaalde beschermingsstatus (links) en type voortouwnemer (rechts) van de selectie (31) van beheerplannen ofwel de evaluatiegroep in vergelijking met alle Natura 2000-gebieden.

\subsubsection{Verzamelen van facts en figures}

Voor een selectie van de toetsingscriteria uit Tabel 2 is een aantal vragen opgesteld (een checklist) om inzicht te krijgen in hoeverre de formulering van de instandhoudingsdoelen in de beheerplannen aan de hieraan gestelde voorwaarden voldoet (zie Tabel 3). 
Tabel 3 Verzameling van facts en figures per toetsingscriterium (zie Tabel 2) uit de beheerplannen op basis van een aantal vragen. Deze vragen zijn deels vergelijkbaar/overeenkomstig met de checkpunten van de checklist voor de beheerplannen, hetgeen ook wordt aangegeven in deze tabel.

\begin{tabular}{|c|c|}
\hline Toetsingscriteria & Vragen \\
\hline Coherent (intern) & $\begin{array}{l}\text { - Wordt er bij de uitwerking van de instandhoudingsdoelen in de beheerplannen rekening } \\
\text { gehouden met de relatieve bijdrage van het gebied aan de staat van instandhouding van een } \\
\text { habitattype of een soort en aan de realisering van de landelijke instandhoudingsdoelen? } \\
\text { Checkpunt } 16 \\
\text { - Zijn de kernopgaven per Natura } 2000 \text {-landschap gebruikt bij de uitwerking van de te } \\
\text { realiseren instandhoudingsdoelstellingen? Zo ja, op welke manier? Checkpunt } 10\end{array}$ \\
\hline $\begin{array}{l}\text { Coherent (ander } \\
\text { beleid) }\end{array}$ & $\begin{array}{l}\text { - Komen de beleidsopgaven ter sprake (PAS, KRW, NNN, FFW en Boswet)? Checkpunt 27-28 } \\
\text { (bestaand beleid en regelgeving), 31-34 (stikstofparagraaf) en 35-38 (waterparagraaf) } \\
\text { - Wordt er uitgewerkt welke van de hieronder vallende maatregelen relevant zijn voor } \\
\text { realisering van de Natura 2000-instandhoudingsdoelstellingen (PAS, KRW, NNN)? } \\
\text { Checkpunt 27-28 (bestaand beleid en regelgeving), 31-34 (stikstofparagraaf) 35-38 } \\
\text { - Wordt er gespecificeerd welke Natura 2000-instandhoudingsdoelstellingen door de wet } \\
\text { worden beschermd en op welke wijze (Flora- en faunawet, Boswet)? Checkpunt 27-28 } \\
\text { (bestaand beleid en regelgeving) }\end{array}$ \\
\hline Prioritering & $\begin{array}{l}\text { - Is er aan de kernopgaven met een Sense of Urgency prioriteit gegeven (t.o.v. de andere } \\
\text { gestelde doelen)? Checkpunt } 24\end{array}$ \\
\hline Specifiek & Meegenomen onder meetbaar \\
\hline Meetbaar & $\begin{array}{l}\text { - Wordt er in meetbare eenheden aangegeven wat voor oppervlakte en welk kwaliteitsniveau } \\
\text { voor het habitattype worden nagestreefd? Checkpunt 13, } 17 \text { en } 18 \\
\text { - Wordt er in meetbare eenheden aangegeven wat voor omvang en welk kwaliteitsniveau er } \\
\text { aan leefgebied voor de soort worden nagestreefd? Checkpunt 4, } 17 \text { en } 20 \\
\text { - Wordt er in meetbare eenheden aangegeven welke populatieomvang men voor de soort } \\
\text { nastreeft (alleen voor HR- en VR-soorten)? Checkpunt 14, } 20\end{array}$ \\
\hline Acceptabel & $\begin{array}{l}\text { - Wordt er in het beheerplan aangegeven of er sociaaleconomisch draagvlak is voor het } \\
\text { beheerplan? Checkpunt 39-40 }\end{array}$ \\
\hline Realistisch & Niet getoetst \\
\hline Tijdgebonden (tijd) & $\begin{array}{l}\text { - Wordt er aangegeven binnen welke termijn men de doelen wil realiseren? Checkpunt } 16,18 \\
\text { en } 24\end{array}$ \\
\hline Consistent & Niet getoetst \\
\hline Alomvattend & Niet getoetst \\
\hline Robuust & Niet getoetst \\
\hline Flexibel & $\begin{array}{l}\text { - Hoe vaak is er voor de Natura } 2000 \text {-instandhoudingsdoelstellingen een hoger ambitieniveau } \\
\text { gehanteerd dan gesteld in de aanwijzingsbesluiten? Checkpunt } 9 \\
\text { - Hoe vaak worden er in het beheerplan naast de Natura 2000-instandhoudingsdoelstellingen } \\
\text { nog andere natuurdoelen gesteld? Checkpunt } 9 \\
\text { - Zijn de complementaire doelen opgenomen in het beheerplan, ondanks dat deze zijn komen } \\
\text { te vervallen? }\end{array}$ \\
\hline
\end{tabular}

\subsubsection{Enquête met voortouwnemers van Natura 2000-gebieden}

Een digitale enquête is opgesteld voor alle voortouwnemers van de Natura 2000-doelen met als doel te achterhalen wat de eventuele oorzaken zijn dat de formulering van de Natura 2000-doelen in de beheerplannen wel/niet voldoen aan de gestelde voorwaarden. Hierbij dient nadrukkelijk opgemerkt te worden dat de in dit onderzoek opgestelde toetsingscriteria als zodanig niet bekend waren bij de ondervraagden.

In totaal zijn 30 voortouwnemers zijn via een e-mail gevraagd de enquête in te vullen. De respons was laag: 5 van de 30 volledig ingevulde enquêtes (16,7 procent). De resultaten zijn dan ook niet representatief, maar geven wel inzicht in eventuele knelpunten die de voortouwnemers ervaren bij het opstellen van de beheerplannen en specifiek bij de nadere uitwerking van de instandhoudingsdoelen op gebiedsniveau in omvang, ruimte en tijd en kwaliteit (zie Bijlage 5). Deze resultaten zijn echter niet verwerkt in dit rapport, omdat dit een vertekend beeld zou kunnen geven. 


\subsection{Resultaten}

\subsubsection{Coherentie (interne samenhang) Natura 2000-doelen}

\subsubsection{Definitie}

Coherentie betreft de interne samenhang, oftewel de samenhang tussen de instandhoudingsdoelen van de Vogelrichtlijn en de Habitatrichtlijn op verschillende ruimtelijke schaalniveaus (Europees, nationaal, regionaal en gebiedsniveau), maar ook de samenhang tussen de instandhoudingsdoelen van de Natura 2000-gebiedenonderling, ofwel de - ruimtelijke - samenhang van het Natura 2000netwerk.

\subsubsection{Motivatie}

De Europese Commissie (2012) stelt dat elk Natura 2000-gebied een bijdrage levert aan de realisatie van een gunstige staat van instandhouding van soorten en/of habitattypen, maar dat dit doel alleen gedefinieerd en bereikt kan worden op het schaalniveau van het natuurlijke verspreidingsgebied van de betreffende soort of het habitattype. Doelen ten aanzien van een gunstige staat van instandhouding van soorten en habitattypen moeten dan ook op het hiervoor geschikte schaalniveau worden bepaald, namelijk per lidstaat, per biogeografische regio en/of op Europees niveau.

Het is belangrijk om de Natura 2000-gebieden zo te selecteren dat er een maximale bijdrage wordt geleverd aan de staat van instandhouding van soorten en habitattypen op nationaal, biogeografisch en Europees niveau (Europese Commissie, 2012). De relatieve bijdrage, ofwel het relatieve belang van de Natura 2000-gebieden wordt op nationaal niveau beoordeeld in de Standard Data Forms conform Bijlage III van de Habitatrichtlijn (zie Bijlage 2). De informatie uit de SDF's vormt dan logischerwijs ook het uitgangspunt voor de formulering van de instandhoudingsdoelen op gebiedsniveau (Europese Commissie, 2012).

\subsubsection{Toepassing}

\section{Natura 2000-doelendocument 2006}

In het Natura 2000-doelendocument 2006 wordt de coherentie ofwel de samenhang tussen de Natura 2000-doelen op landelijk en gebiedsniveau bewaakt door het principe van strategisch lokaliseren. Bij de doorvertaling van de landelijke instandhoudingsdoelen naar de instandhoudingsdoelen op gebiedsniveau is gelet op de huidige kwaliteiten en de beste mogelijkheden om op termijn een duurzame situatie te behouden of te verkrijgen tegen een zo gering mogelijke inspanning (ministerie van Landbouw, Natuur en Voedselkwaliteit, 2006). Hier is invulling aan gegeven door de landelijke doelen via kernopgaven per Natura 2000-landschap door te vertalen naar de gebiedsdoelen. De kernopgaven hebben in het bijzonder betrekking op habitattypen en soorten die sterk onder druk staan en/of waarvoor Nederland van groot of van zeer groot belang is en geven in feite ook aan welke gebieden de relatief grootste bijdrage leveren aan de realisering van de landelijke doelen. Bij de toedeling van de kernopgaven aan de gebieden is vooral de actuele kwaliteit of de mate waarin een gebied een bijdrage levert of kan leveren aan het realiseren van het landelijke doel bepalend. De toedeling van de kernopgaven is gebaseerd op een inschatting van de huidige bijdrage van het gebied aan de van toepassing zijnde doelen op landelijk niveau.

\section{Aanwijzingsbes/uiten}

In de aanwijzingsbesluiten van de Natura 2000-gebieden wordt in hoofdstuk 3 van de Nota van toelichting een korte toelichting gegeven op de landschappelijke context en de natuurlijke kenmerken van het gebied. In Bijlage B van de Nota van toelichting wordt inzichtelijk gemaakt hoe de landelijke doelstelling is vertaald naar Natura 2000-gebieden. De kernopgaven zijn niet opgenomen in de aanwijzingsbesluiten. 


\section{Beheerplannen}

In de checklist beheerplannen staat onder de paragraaf instandhoudingsdoelen dat rekening gehouden dient te worden met de relatieve bijdrage van het Natura 2000-gebied aan de landelijke staat van instandhouding van soorten en habitattypen en dat de kernopgaven uit het Natura 2000doelendocument moeten worden overgenomen. De relatieve bijdrage van het Natura 2000-gebied en de landelijke staat van instandhouding (SvI) van soorten en habitattypen waar het betreffende gebied voor is aangewezen, komt in respectievelijk 16 en 21 van de 31 geëvalueerde beheerplannen ter sprake (zie Figuur 5). In respectievelijk 1 en 2 van deze beheerplannen komt naar voren dat de relatieve bijdrage van het gebied en de landelijke SvI (mede) ook zijn gebruikt bij de afweging wat men wil realiseren en wat men aan middelen hiervoor besluit in te zetten, ofwel bij de prioritering van de doelen (Van Vreeswijk et al., 2016). In 25 van de 31 geëvalueerde beheerplannen wordt aangegeven wat voor kernopgaven er gelden. In 14 daarvan wordt concreet uitgewerkt hoe men er invulling aan geeft.

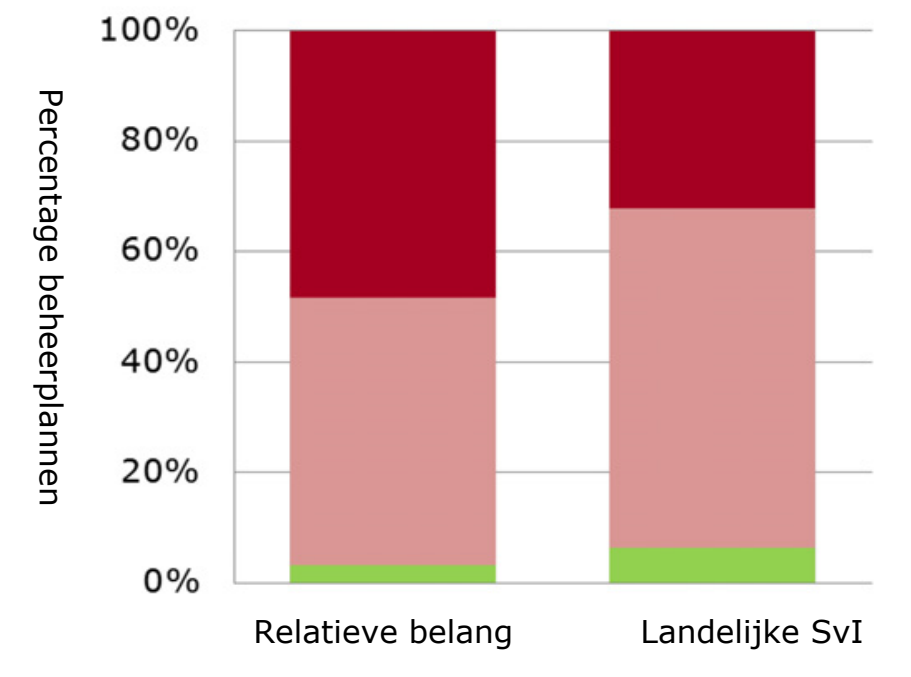

Relatieve bijdrage en landelijke SvI niet benoemd

Relatieve bijdrage en landelijke SvI wel benoemd, maar niet gebruikt bij prioritering van doelen

Relatieve bijdrage en landelijke SvI gebruikt bij prioritering van doelen

Figuur 5 Het gebruik van de relatieve bijdrage van het gebied aan de realisering van de landelijke doelen en de landelijke staat van instandhouding in de 31 geëvalueerde beheerplannen.

\subsubsection{Coherent (samenhang met ander beleid)}

\subsubsection{Definitie}

Coherentie betreft de samenhang van de instandhoudingsdoelen en -maatregelen van de Vogelrichtlijn en de Habitatrichtlijn met de doelen en maatregelen van andere Europese richtlijnen (bv. de Kaderrichtlijn Water en de Kaderrichtlijn Marien) en met ander provinciaal, nationaal en internationaal beleid, bijvoorbeeld beleid t.a.v. economische sectoren, zoals de landbouw-, visserij- en recreatiesector.

\subsubsection{Motivatie}

De Europese Commissie stelt in de Vogelrichtlijn en Habitatrichtlijn en in de notitie over de formulering van de instandhoudingsdoelen op gebiedsniveau (Europese Commissie, 2012) geen voorwaarden wat betreft de coherentie met andere beleidssectoren. Wel wordt aangeven dat er rekening gehouden dient te worden met sociaaleconomische belangen. Op Europees niveau zijn er echter wel initiatieven voor een meer integrale aanpak. De Rijksnatuurvisie 2014 gaat wel nadrukkelijk in op de samenhang tussen het natuurbeleid en andere beleidssectoren. 


\subsubsection{Toepassing}

Natura 2000-doelendocument 2006

In het Natura 2000-doelendocument 2006 wordt het belang van de samenhang met ander beleid aangegeven door een van de acht hoofdlijnen, te weten maximaal aans/uiten bij bestaand beleid. In hoofdstuk 7 van het Natura 2000-doelendocument wordt nader ingegaan op de perspectieven voor de Natura 2000-doelen in relatie tot ander beleid. Een relatie wordt gelegd met het mestbeleid. Dit komt nu deels terug in de Programmatische Aanpak Stikstof (PAS), te weten de bron- en effectgerichte maatregelen om de effecten van stikstofdepositie (deels afkomstig van de landbouw) op de kwaliteit van habitattypen en leefgebieden van soorten te verminderen. Ook wordt er een relatie gelegd met het verdrogingsbeleid, mede in het licht van het Investeringsbudget Landelijk Gebied (ILG). Het ILG is bij de decentralisatie van het natuurbeleid in 2014 afgeschaft. Veel antiverdrogingsmaatregelen komen echter weer terug in de PAS. Een relatie wordt gelegd met de Kaderrichtlijn Water (KRW). De Gewenste Grondwater- en Oppervlaktewater Regimes (GGOR) worden opgepakt binnen de stroomgebiedsbeheerplannen van de KRW volgens het doelendocument. Wat betreft de ruimtelijke samenhang wordt ingegaan op de robuuste verbindingen, een begrip dat bij de Herijking van de EHS echter is komen te vervallen. Verwezen wordt naar het Programma Beheer, ofwel de subsidies voor natuurbeheer (SN) en agrarisch natuurbeheer (ANLB), hetgeen inmiddels vervangen is door respectievelijk het Subsidiestelsel Natuur- en Landschapsbeheer (SNL) en het Agrarisch Natuur- en Landschapsbeheer (ANLB). De Flora- en faunawet, de Natuurbeschermingswet en de Boswet zullen per 1 januari 2017 worden vervangen door de nieuwe Wet natuurbescherming.

De samenhang tussen Natura 2000 en KRW is verankerd door de opname van de Natura 2000gebieden in het KRW-register van beschermde gebieden. In 2009 zijn de stroomgebiedsbeheerplannen vastgesteld. Daarin zijn in 2015 de maatregelen opgenomen voor de verdrogingsaanpak conform de afspraken tussen Rijk en provincies over de TOP-lijsten en over het realiseren van goede watercondities in dertig 'sense of urgency'-gebieden. Deze 'sense of urgency'-gebieden zijn Natura 2000-gebieden met een watergerelateerde, urgente, ecologische opgave voor bepaalde habitattypen, die in het doelendocument aangegeven waren. Het realiseren van de watercondities in deze gebieden is op korte termijn nodig, omdat anders binnen nu en tien jaar mogelijk een onherstelbare situatie ontstaat ten aanzien van het betreffende natuurdoel. Bij een conflicterend doel tussen KRW en Natura 2000 in een bepaald gebied zal de keuze gemaakt worden bij het opstellen van het Natura 2000beheerplan dan wel bij het opstellen van het stroomgebiedsbeheerplan (Programmadirectie Natura 2000, 2011b).

\section{Aanwijzingsbes/uiten}

De aanwijzingsbesluiten zijn bedoeld voor het wettelijk vastleggen van de doelen voor Natura 2000waarden. In de aanwijzingsbesluiten wordt daarom niet specifiek ingegaan op de afstemming met ander (natuur)beleid.

\section{Beheerplannen}

In de checklist van de beheerplannen is een aparte stikstof- (PAS) en een waterparagraaf (KRW) opgenomen. Verwacht wordt dat de stikstof- en watermaatregelen in desbetreffende paragrafen in de beheerplannen duidelijk worden benoemd en onderbouwd. In 84 procent van de geëvalueerde beheerplannen wordt uitgewerkt wat voor maatregelen in het kader van de PAS worden genomen of er wordt, in het geval dat de PAS voor het gebied niet relevant is, duidelijk aangegeven dat de PAS niet relevant is (zie Figuur 6). In 3 beheerplannen is niet duidelijk beschreven welke maatregelen nu in het kader van de PAS worden genomen en in 2 beheerplannen wordt de PAS niet besproken. In de beheerplannen waarin de PAS-maatregelen zijn uitgewerkt, bestaat het maatregelenpakket grotendeels uit PAS-maatregelen. In 35 procent van de geëvalueerde beheerplannen wordt uitgewerkt wat voor maatregelen in het kader van de KRW worden genomen of er wordt aangegeven dat de KRW niet relevant is (Figuur 6). In 2 beheerplannen komt de KRW niet ter sprake. In de andere 18 beheerplannen wordt de KRW vaak wel toegelicht, of wordt bijvoorbeeld aangegeven dat de KRWopgave goed samengaat met de uitvoering van het Natura 2000-beleid, maar wordt niet uitgewerkt op welke manier zich dit naar het maatregelenpakket vertaald. 


\section{Coherentie PAS en Natura 2000}

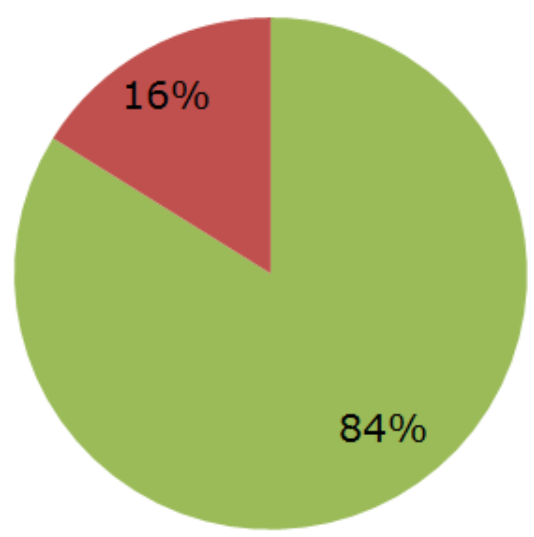

De beheerplannen waarin is uitgewerkt wat voor maatregelen i.h.k.v. de PAS worden genomen of waarin is aangegeven dat de PAS niet relevant is voor het gebied.

De beheerplannen waarin er niet duidelijk is beschreven welke maatregelen i.h.k.v. de PAS zijn genomen of waarin de PAS niet is besproken.

\section{Coherentie KRW en Natura 2000}

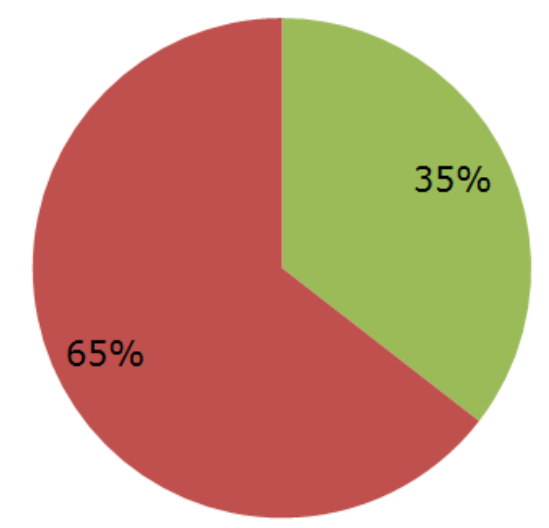

De beheerplannen waarin is uitgewerkt wat voor maatregelen i.h.k.v. de KRW worden genomen of waarin is aangegeven dat de KRW niet relevant is voor het gebied.

De beheerplannen waarin er niet duidelijk is beschreven welke maatregelen i.h.k.v. de KRW zijn genomen of waarin de KRW niet is besproken.

Figuur 6 Coherentie Natura 2000-beleid met stikstokbeleid (PAS) en waterbeleid (KRW).

In de checklist beheerplannen is ook een paragraaf over bestaand beleid en wet- en regelgeving opgenomen. Het Natuurnetwerk Nederland (NNN) en daarmee samenhangend het Subsidiestelsel Natuur en Landschapsbeheer (SNL) en het Agrarisch Natuur en Landschapsbeheer (ANLB) worden hier niet expliciet genoemd, maar zijn voor de realisatie van de Natura 2000-doelen wel relevant. In 26 procent van de geëvalueerde beheerplannen wordt aangegeven welke maatregelen gerelateerd zijn aan het NNN-beleid (zie Figuur 7). Zo wordt er bijvoorbeeld in het beheerplan van de Sallandse Heuvelrug een maatregel omschreven voor de korhoen, waarbij vermeld wordt dat deze onder het NNN valt en zal worden gefinancierd door SNL-gelden en wordt een maatregel voor de kamsalamander voorgesteld die wordt uitgevoerd buiten het Natura 2000-gebied in de NNN-zone. Het Nationaal Natuurnetwerk (NNN) komt in 6 beheerplannen niet ter sprake. In de andere 17 beheerplannen waar de NNN wel ter sprake komt, samen 74 procent van het totaal van geëvalueerde beheerplannen, wordt de relatie tussen het NNN en het Natura 2000-gebied in algemene termen besproken. Zo wordt vaak gemeld dat het NNN en het Natura 2000-beleid goed op elkaar aansluiten, zonder dat hier wordt gespecificeerd wat dan zo goed op elkaar aansluit. Andere redelijk vaak terugkomende uitspraken zijn de melding dat het NNN bijdraagt aan de realisatie van de Natura 2000-doelen, dat het Natura 2000-gebied onderdeel is van het NNN en dat de maatregelen (deels) zijn geborgd middels NNN-gelden. 


\section{Coherentie NNN en Natura 2000}

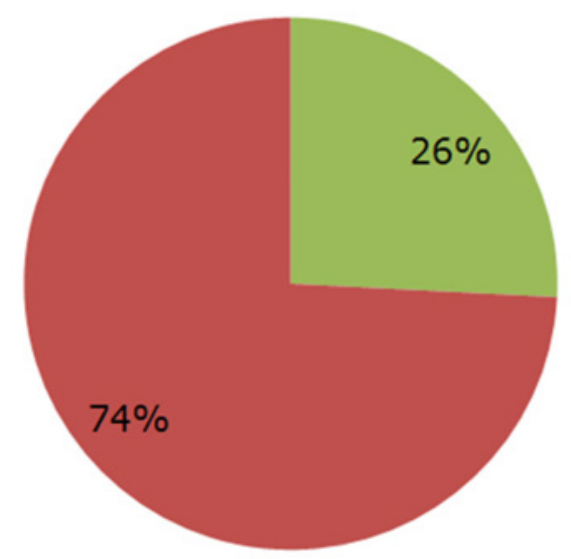

Er is een duidelijke link tussen het NNN en één of meer Natura 2000-maatregelen.

Er is geen duidelijke link tussen het NNN en één of meer Natura 2000-maatregelen of het NNN wordt in het beheerplan niet besproken.

Figuur 7 Coherentie Natura 2000-beleid met het Nederlandse Natuurnetwerk (NNN).

\subsubsection{Prioritering}

\subsubsection{Definitie}

Prioritering gaat over de voorkeur geven aan de realisatie van een gunstige staat van instandhouding van bepaalde soorten en habitattypen, afhankelijk van het relatieve belang van Nederland voor de Europese Unie (EU-belang) en op een lager schaalniveau het relatieve belang van het Natura 2000gebied voor Nederland (nationaal belang). Prioritering is ook afhankelijk van de huidige staat van instandhouding van soorten en habitattypen en de urgentie voor het nemen van maatregelen om verslechtering te voorkomen.

\subsubsection{Motivatie}

De Europese Commissie (2012) stelt dat de EU-lidstaten prioriteiten moeten stellen afhankelijk van het relatieve belang van het Natura 2000-gebied voor de instandhouding van soorten en habitattypen, de - ruimtelijke - samenhang van het Natura 2000-netwerk en de drukfactoren en bedreigingen waaraan het Natura 2000-gebied wordt blootgesteld. Prioriteit moet worden gegeven aan die soorten en habitattypen waarvoor de urgentie van het nemen van maatregelen het hoogst is. Deze prioriteiten kunnen op verschillende schaalniveaus bepaald worden, te weten op Europees, nationaal, regionaal of gebiedsniveau.

\subsubsection{Toepassing}

\section{Natura 2000-doelendocument}

In het Natura 2000-doelendocument is een prioritering toegepast conform drie van de acht hoofdlijnen, te weten behoud waar nodig verbeteren, hogere inzet bij groter relatief belang en doen wat redelijkerwijs van Nederland verwacht kan worden. In het Natura 2000-doelendocument is hier invulling aan gegeven via de kernopgaven, de Sense of Urgency (SoU) opgaven en de ten gunste van opgaven. Een Sense of Urgency is toegekend als binnen nu en tien jaar mogelijk een onherstelbare situatie ontstaat.

\section{Aanwijzingsbes/uiten}

In de aanwijzingsbesluiten worden geen prioriteiten gesteld, anders dan het onderscheid tussen de behoud- en herstelopgaven: behoud waar nodig verbeteren. 


\section{Beheerplannen}

In de checklist beheerplannen staat onder de paragraaf maatregelen vermeld dat de maatregelen in de Natura 2000-gebieden met een SoU-prioriteit prioriteit hebben en dat deze SoU-maatregelen ook gedurende de eerste beheerplanperiode genomen moeten worden. $\mathrm{Er}$ is in 12 van de 31 geëvalueerde beheerplannen sprake van een of meer Sense of Urgency (SoU)-opgaven. In 42 procent van de 12 geëvalueerde beheerplannen wordt uitgelegd hoe men invulling en prioriteit heeft gegeven aan deze SoU-opgaven (zie Figuur 8). In 2 van deze beheerplannen worden de SoU's niet besproken en in 5 van de 12 beheerplannen worden de SoU's wel genoemd, maar wordt niet expliciet besproken hoe men invulling heeft gegeven aan deze SoU's.

\section{Prioritering a.d.h.v. sense of urgency}

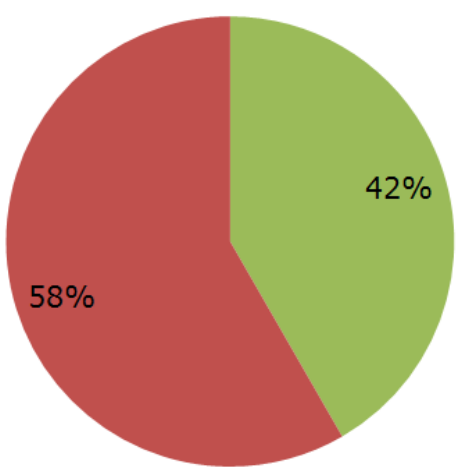

De gebieden waar een SoU geldt en waarvoor in de beheerplannen is uitgewerkt hoe men hier prioriteit aan geeft.

De gebieden waar een SoU geldt en waarvoor

niet in de beheerplannen is uitgewerkt hoe men

hier prioriteit aan geeft of waar in de

beheerplannen niet is gesproken over de SoU.

Figur $8 \quad$ Prioritering Natura 2000-doelen getoetst op basis van de uitwerking van de SoUopgaven in de beheerplannen.

\subsubsection{Specifiek}

\subsubsection{Definitie}

Met specifiek wordt door de Europese Commissie bedoeld dat de instandhoudingsdoelen geformuleerd worden voor specifieke soorten en habitattypen en met duidelijk gedefinieerde condities (ecologische vereisten) waaraan voldaan moet worden om desbetreffende instandhoudingsdoelen te bereiken.

be specific - relate to a particular interest feature (species or habitat type) and define the condition(s) required to satisfy the conservation objective (Europese Commissie, 2012).

\subsubsection{Motivatie}

Indien doelen niet specifiek zijn geformuleerd is het ook niet mogelijk om te beoordelen of de doelen behaald zijn. Dat betekent dat er ook niet (bij-)gestuurd kan worden. Zie ook onder meetbaarheid.

\subsubsection{Toepassing}

\section{Natura 2000-doelendocument}

In het Natura 2000-doelendocument is 'specifiek' niet als een voorwaarde opgenomen. Op zich zijn de Natura 2000-doelen specifiek in die zin dat er per soort en per habitattype en per aspect van de staat van instandhouding doelen zijn geformuleerd, dit met uitzondering van het aspect toekomstperspectief. De Natura 2000-doelen zijn geformuleerd in termen van behoud- of herstelopgaven. Alleen voor de VRsoorten zijn ook concrete aantallen voor populatiegrootte genoemd. 


\section{Aanwijzingsbes/uiten}

In aanwijzingsbesluiten zijn de doelen op vergelijkbare wijze geformuleerd als in het Natura 2000doelendocument namelijk in termen van behoud- en herstelopgaven. Alleen voor de VR soorten worden ook concrete aantallen voor populatiegrootte genoemd. Voor bijvoorbeeld leefgebied of kwaliteit van een habitattype wordt in het toelichting van het doel heel zelden aangegeven wat verbeterd moet worden.

\section{Beheerplannen}

In de beheerplannen zijn de doelen uit de aanwijzingsbesluiten overgenomen. De doelen worden op verschillende wijze wel/niet nader uitgewerkt, zie volgende paragraaf.

\subsubsection{Meetbaar}

\subsubsection{Definitie}

Met meetbaar wordt door de Europese Commissie bedoeld dat de doelen toetsbaar zijn, zodat het mogelijk is om de mate van doelbereik te monitoren en te beoordelen en hierover te rapporteren. Dat betekent dat doelen in de vorm meetbare variabelen (bv. oppervlakte), meeteenheden (bv. aantal hectares) en parameters (bv. een trend) geformuleerd worden.

be measurable and reportable - enabling monitoring to be undertaken to determine whether the conservation objectives are being met and for the purposes of Article 17 of the Habitats Directive (Europese Commissie, 2012).

\subsubsection{Motivatie}

Indien doelen niet meetbaar gedefinieerd worden is het ook niet mogelijk om deze te monitoren en te evalueren (toetsen) en hierover te rapporteren. Dat betekent dat er ook niet (bij-)gestuurd kan worden.

\subsubsection{Toepassing}

Natura 2000-doelendocument

In het Natura 2000-doelendocument is meetbaarheid niet als een voorwaarde opgenomen. De doelen t.a.v. kwantiteit zijn uitgedrukt ofwel uit te drukken in meetbare variabelen (verspreiding, populatiegrootte en oppervlakte) en meeteenheden (aantal 10*10 km hokken, aantal ha, aantal individuen). De doelen t.a.v. kwaliteit zijn niet meetbaar geformuleerd. Verwacht wordt dat de doelen in de beheerplannen nader uitgewerkt worden in omvang, ruimte, tijd (en kwaliteit).

\section{Aanwijzingsbes/uiten}

Alleen voor de VR-soorten worden concrete aantallen voor populatiegrootte genoemd. De overige doelen worden alleen in termen van behoud- of herstelopgaven geformuleerd.

\section{Beheerplannen}

In de checklist beheerplannen staat onder de paragraaf instandhoudingsdoelen dat er een volledige beschrijving van de natuurwaarden (kwantiteit en kwaliteit) opgenomen dient te worden op basis waarvan na zes jaar ( 1 beheerplanperiode) kan worden geconstateerd dat er een verandering heeft plaatsgevonden of niet. De kwaliteitsdoelen voor de habitattypen moeten concreet en toetsbaar zijn uitgewerkt met de elementen uit het profielendocument.

\section{Oppervlakte leefgebied of habitattype}

Voor 14 procent van de Natura 2000-doelen wordt aangegeven hoeveel hectare men in totaal aan oppervlakte leefgebied of habitattype nastreeft (Categorie A; Figuur 9). Vaak betreft dit habitattypen (Categorie A; Figuur 10). Voor 20,1 procent van de Natura 2000-doelen is niet specifiek aangegeven hoeveel hectare men aan leefgebied of habitattype wil behouden, maar kan dit wel herleid worden omdat er elders in het beheerplan is aangegeven hoeveel hectare het huidige habitattype of leefgebied omvat (Categorie B1; Figuur 10). Dit is echter alleen mogelijk als het om een behoudsopgave gaat en betreft dus ook alleen doelen met een behoudsopgave. 


\section{Kwaliteit leefgebied of habitattype}

In 24 beheerplannen is voor in totaal 246 habitattypen, HR- of VR soorten een huidig en/of toekomstig kwaliteitsniveau benoemd (Categorie A, B1, B2). Voor 9,3 procent van alle geëvalueerde Natura 2000doelen is aangegeven wat voor kwaliteitsniveau men in de toekomst nastreeft (Categorie $A$;

Figuur 11). Dit betreft vrijwel alleen habitattypen (Categorie A; Figuur 11). Bij 30,9 procent van de Natura 2000-doelen is er niet concreet benoemd welke kwaliteit men in de toekomst nastreeft, maar kan dit wel herleid worden, omdat men aangeeft wat het huidige kwaliteitsniveau van het habitattype of leefgebied is (Categorie B1; Figuur 11). Dit is echter alleen mogelijk als het om een behoudsopgave gaat en betreft dus ook alleen doelen met een behoudsopgave.

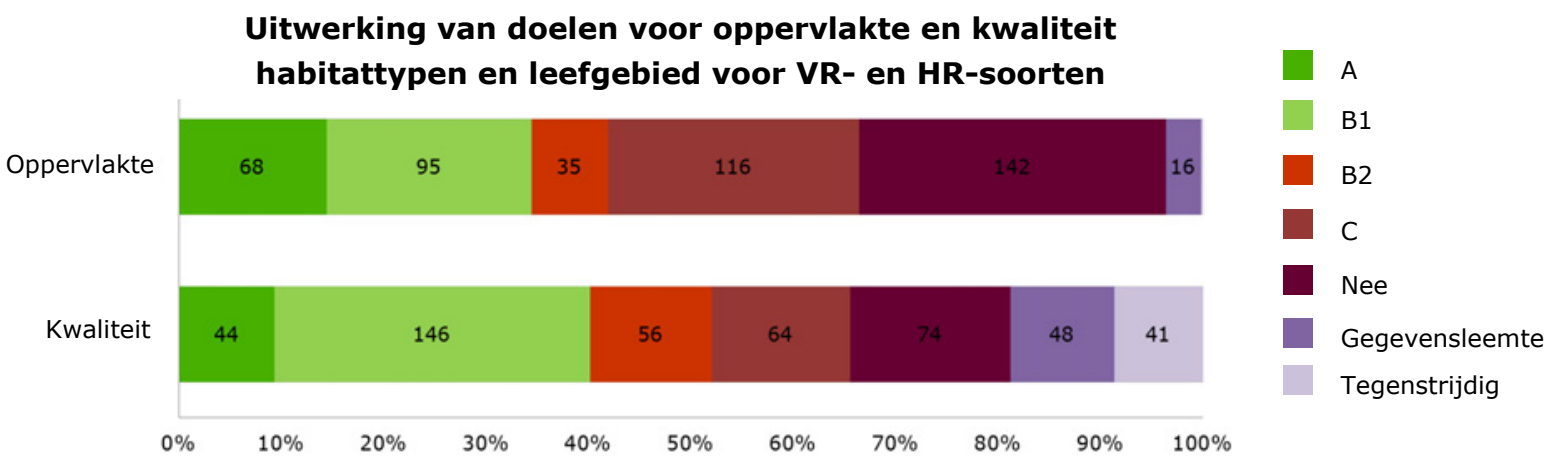

Figuur 9 Het percentage instandhoudingsdoelstellingen waarvan het doel voor de oppervlakte en kwaliteit van het habitattype of leefgebied van soorten is uitgedrukt in meetbare eenheden, alle doeltypen samengenomen. Voor uitleg categorieën, zie kader.

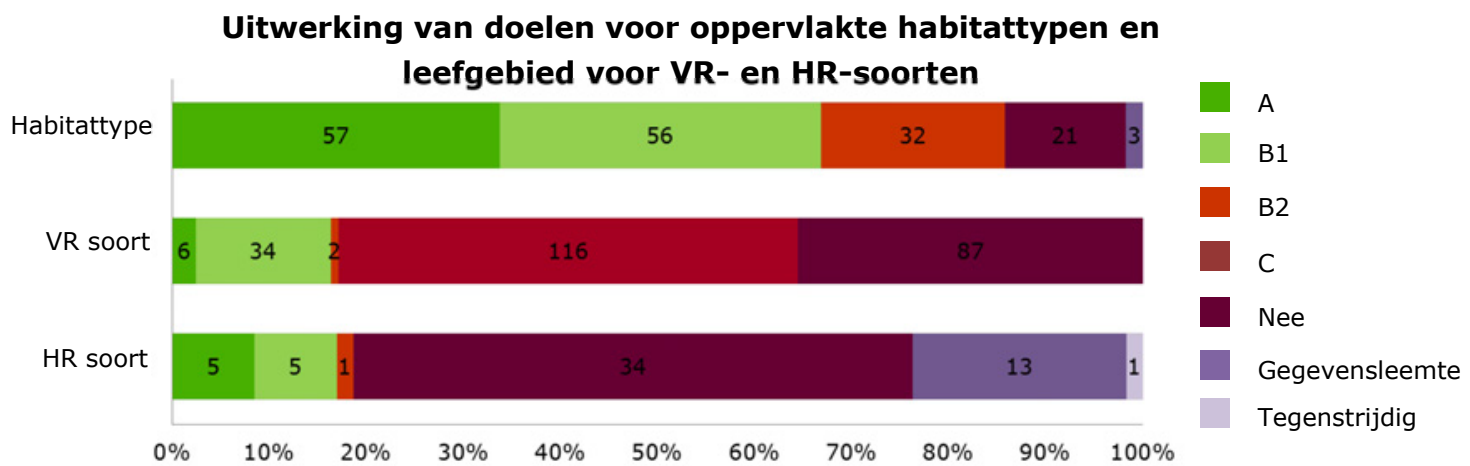

Figuur 10 Het percentage instandhoudingsdoelstellingen waarvan het doel voor de oppervlakte van het habitattype of leefgebied van soorten is uitgedrukt in meetbare eenheden, per doeltype (Habitattype, VR-soort en HR-soort). Voor uitleg categorieën, zie kader. 


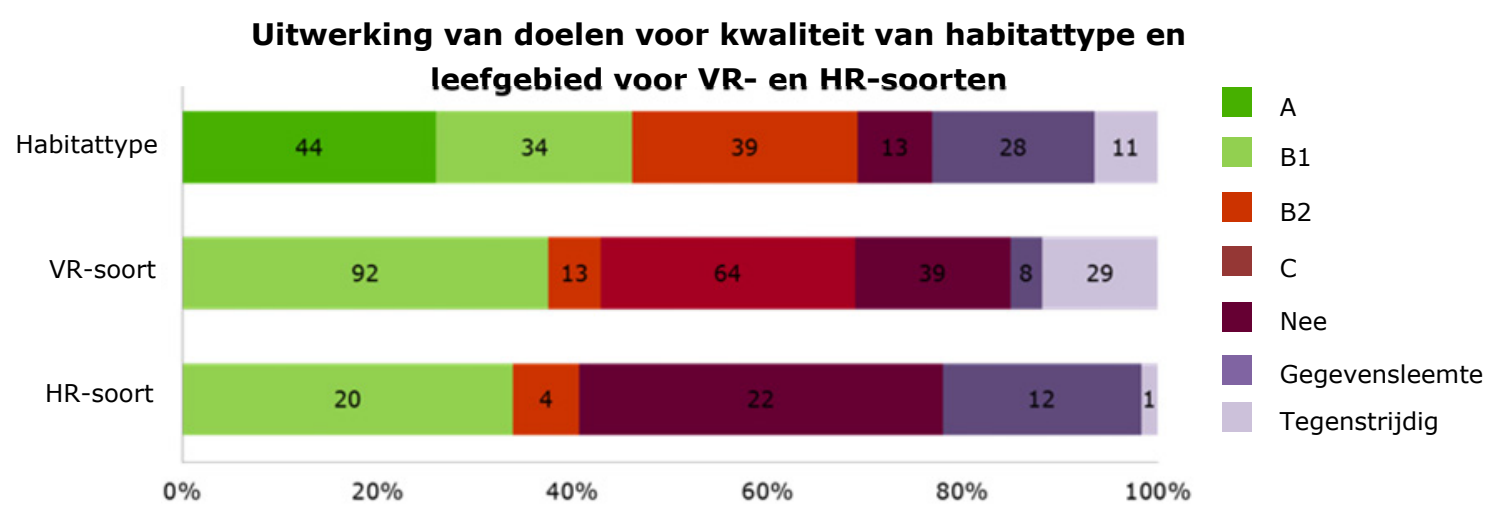

Figuur 11 Het percentage instandhoudingsdoelstellingen waarvoor is aangegeven welk kwaliteitsniveau van het habitattype of leefgebied van soorten men als doel heeft, per doeltype (Habitattype, VR-soort en HR-soort). Voor uitleg categorieën, zie kader.

\section{Betekenis van de categorisering bij figuren 7-9:}

Categorie $A \quad J a$, er wordt in meetbare eenheden aangegeven wat men nastreeft.

Categorie B1 Nee, er wordt niet expliciet in meetbare eenheden aangegeven wat men nastreeft. Dit is wel te herleiden, omdat er wel in meetbare eenheden is aangegeven wat de huidige situatie is. Deze categorie is alleen van toepassing als er voor het habitattype of de soort een behoudsopgave geldt of, in geval van de VR-soort, als het doel t.a.v. de populatieomvang niet expliciet wordt vermeld, maar wel te herleiden is, omdat er wordt gekeken of de eraan de doelstelling (zoals vastgesteld in het aanwijzingsbesluit) wordt voldaan door de huidige populatieomvang met deze doelstelling te vergelijken.

Categorie B2 Nee, er wordt niet expliciet in meetbare eenheden aangegeven wat men nastreeft. Hoewel er wel in meetbare eenheden is aangegeven wat de huidige situatie is, is deze niet te herleiden, omdat er voor de soort een uitbreidingsopgave is vastgesteld.

Categorie C Alleen van toepassing voor de opgave voor omvang en kwaliteit van het leefgebied van de doelen met een kwantitatieve populatie doelstelling (VR-soort). De omvang en/of kwaliteit van het leefgebied wordt niet expliciet uitgewerkt, maar beoordeeld a.d.h.v. de populatie doelstelling (is indicatie voor draagkracht).

Nee Nee, er wordt niet expliciet in meetbare eenheden aangegeven wat men nastreeft. Zowel de huidige als de toekomstige situatie wordt niet uitgedrukt in meetbare eenheden.

Gegevensleemte Er kan niet worden aangegeven wat men nastreeft, omdat er onvoldoende informatie bekend is.

Tegenstrijdig Nee, er wordt niet expliciet in meetbare eenheden aangegeven wat men nastreeft. De huidige situatie wordt wel besproken, maar hier wordt op meerdere plekken verschillende (meetbare) termen voor gebruikt, zodat er niet met zekerheid kan worden gezegd wat nu het doel is. 
Methodiek achter beoordeling kwaliteitsniveau van habitattypen

Voor de habitattypen wordt in 69 procent van de habitat-gebiedscombinatie aangegeven wat het huidig en/of toekomstig kwaliteitsniveau is (Categorie A, B1, B2; Figuur 11). In veel gevallen wordt niet toegelicht of er een bepaalde methodiek is gebruikt en als dit wel is gedaan, is er alsnog vaak onduidelijk wat de kwantiteit achter de kwaliteitsniveaus is. Zo wordt maar in 12 van de 24 beheerplannen, waarin voor een of meer doelen het huidig en/of toekomstig kwaliteitsniveau is gegeven, toegelicht op basis waarvan men tot de kwaliteitsbeoordeling is gekomen. Dit betreft met name beoordelingen van habitattypen ( 10 beheerplannen). De beoordeling van deze habitattypen is in alle 10 de beheerplannen gedaan aan de hand van de vier kwaliteitsaspecten van het profielendocument. In één beheerplan is er daarnaast ook nog beoordeeld met de door Bijlsma et al. (2008) ten behoeve van de provincie Gelderland ontwikkelde beoordelingsmethode (Landgoederen Brummen). De termen die er gebruikt zijn voor de kwaliteitsniveaus zijn echter verschillend. Zo wordt de kwaliteit volgens de beoordelingsmethodiek van Bijlsma et al. (2008) beoordeeld met basaal, voldoende en goed. In andere beheerplannen echter worden andere kwaliteitscategorieën gebruikt, zoals (1) min of meer constant; (2) goed of matig; (3) goed, matig, of slecht en (4) (zeer/matig) ongunstig en (matig) gunstig.

De enige beheerplannen (4) waarin voor de meeste (maar niet alle) kwaliteitsparameters is aangegeven welke kwantitatieve waarden zijn gehanteerd, zijn van voortouwnemer provincie Zuid-Holland. In deze beheerplannen wordt dezelfde beoordelingsmethodiek gehanteerd.

Methodiek achter beoordeling kwaliteitsniveau van het leefgebied van HR-soorten

Van de 12 beheerplannen waarin wordt toegelicht op basis waarvan men tot de kwaliteitsbeoordeling is gekomen, betreft dit in 3 beheerplannen (ook) beoordelingen van het leefgebied van HR-soorten. Deze beheerplannen zijn alle drie van dezelfde voortouwnemer (Provincie Zuid-Holland), maar er wordt op verschillende aspecten beoordeeld. In beheerplan Solleveld \& Kapittelduinen en Duinen Goeree \& Kwade Hoek wordt aangegeven dat de kwaliteit van het leefgebied wordt beoordeeld a.d.h.v. bepaalde vereisten die betrekking hebben op biotoop, ecologische vereisten en omvang. Deze beoordeling kent twee categorieën: Voldoet (alle vereisten aanwezig) of Voldoet niet (een of meer van de vereisten). In beheerplan Nieuwkoopse Plassen en de Haeck wordt de methodiek achter de kwaliteitsbeoordeling niet toegelicht, maar is deze wel af te leiden. In dit beheerplan wordt de kwaliteit beoordeeld aan de hand van de aspecten Ecologische Randvoorwaarden, Abiotiek en Samenhang met andere gebieden, met een eindoordeel in termen van slecht, matig, goed of onbekend.

Methodiek achter beoordeling kwaliteitsniveau van het leefgebied van VR-soorten

Van de 12 beheerplannen waarin wordt toegelicht op basis waarvan men tot de kwaliteitsbeoordeling is gekomen, betreft dit in 4 beheerplannen (ook) beoordelingen van het leefgebied van VR-soorten. Drie van deze beheerplannen zijn van dezelfde voortouwnemer (Provincie Zuid-Holland). De kwaliteit van het leefgebied is echter, net als bij de HR-soorten, op verschillende wijze beoordeeld. In beheerplan Goeree \& Kwade Hoek en Broekvelden, Vettenbroek \& Polder Stein wordt beoordeeld a.d.h.v. bepaalde vereisten die betrekking hebben op (broed)biotoop, ecologische vereisten en omvang en met de

beoordelingscategorieën 'voldoet' en 'voldoet niet'. In beheerplan Nieuwkoopse Plassen en de Haeck wordt de methodiek achter de kwaliteitsbeoordeling (net als bij de HR-soorten) niet toegelicht, maar is deze wel af te leiden. In dit beheerplan wordt de kwaliteit beoordeeld aan de hand van de aspecten Ecologische Randvoorwaarden, Abiotiek voor broed-, rust- en foerageergebied en (alleen voor de broedvogels) het aspect Compleetheid m.b.t. moerastypen voor het leefgebied, met een eindoordeel in termen van slecht, matig of goed.

\section{Populatiegrootte}

Bij de VR-soorten wordt in 33 procent van de VR-soort gebiedscombinaties duidelijk dat men de populatiedoelstelling, zoals gesteld in het aanwijzingsbesluit, ook daadwerkelijk nastreeft (Categorie A; Figuur 12). In 54 procent van de VR-soort gebiedscombinaties is dit minder duidelijk aangegeven (Categorie B1; Figuur 12). Bij deze VR-soort gebiedscombinaties wordt alleen de populatiedoelstelling van het aanwijzingsbesluit opgesomd en wordt niet expliciet vermeld of dit ook het doel is dat men nastreeft. Dit is echter wel te herleiden, omdat in deze beheerplannen in tekst of tabel wordt aangegeven hoe de huidige populatie zich verhoudt ten opzichte van de populatiedoelstelling van het aanwijzingsbesluit. Met deze vergelijking wordt gesuggereerd dat men de populatiedoelstelling van het aanwijzingsbesluit als doel heeft overgenomen. Bij een aantal VR-soortgebiedscombinaties blijft een dergelijke link echter achterwege en kan daarom niet met zekerheid worden gezegd wat men als doel nastreeft (Categorie B2 en Nee; Figuur 12).

In 15 procent van de 59 geëvalueerde HR-soort-gebiedscombinaties wordt in aantallen individuen uitgedrukt wat de huidige en/of toekomstige populatie is/dient te worden (Categorie A, B1 en B2; Figuur 10). De soorten waarvan daadwerkelijk wordt aangegeven hoeveel individuen men in de toekomst wil nastreven, zijn de gewone en grijze zeehond in de Voordelta en de gevlekte witsnuitlibel 
van het Lonnekermeer. Er is bij 29 procent van de HR-soort-gebiedscombinaties aangegeven dat er onvoldoende informatie bekend is over de populatieomvang (Gegevensleemte; Figuur 10). Dit geldt voor alle gebieden waar de bittervoorn $(n=4)$, grote en kleine modderkruiper (respectievelijk $n=2$; $n=3)$, kruipend moerasscherm $(n=1)$ en de rivierdonderpad $(n=1)$ als doel is aangewezen. Verder is er ook sprake van een gegevensleemte in een aantal van de gebieden waar de kamsalamander $(n=5$, van totaal 8 gebieden) en de zeggekorfslak als doel zijn aangewezen ( $n=1$, van totaal 3 gebieden). Voor de overige HR-soort-gebiedscombinaties (56 procent) wordt niet aangegeven uit hoeveel individuen de huidige populatie bestaat of welke populatieomvang aan individuen men wil nastreven.

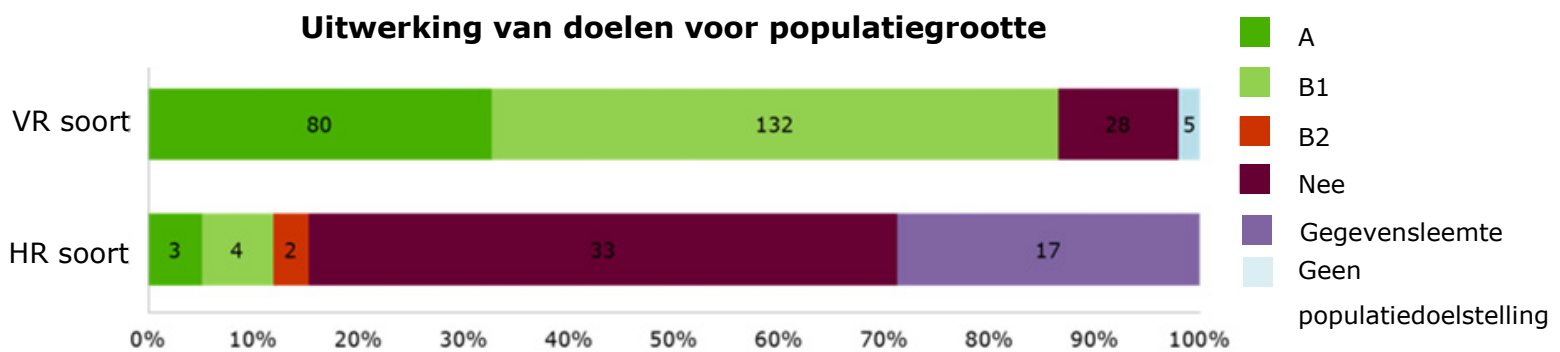

Figuur 12 Het percentage instandhoudingsdoelstellingen waarvan het doel voor de populatiegrootte van de VR- en HR-soorten is uitgedrukt in meetbare eenheden. Voor uitleg categorieën, zie kader.

\subsubsection{Acceptabel}

\subsubsection{Definitie}

Acceptabel betekent dat er voor de doelen maatschappelijk en politiek-bestuurlijk draagvlak is.

\subsubsection{Motivatie}

In de EU-richtlijnen of de Commission Note is acceptabel niet expliciet vermeld, behalve dat er rekening gehouden dient te worden met sociaaleconomische belangen. In de Rijksnatuurvisie 2014 heeft men het over het samengaan met maatschappelijke en economische ontwikkelingen.

\subsubsection{Toepassing}

\section{Natura 2000-doelendocument}

In het Natura 2000-doelendocument wordt acceptabel niet als zodanig als voorwaarde benoemd, maar via het principe van strategisch lokaliseren is hier wel rekening mee gehouden: behoud of herstel daar nastreven waar de grootste potentie ligt en dit gemakkelijk kan, zonder afbreuk te doen aan de ecologische uitgangspunten en ambities. De instandhoudingsdoelstellingen zijn zó gekozen en gelokaliseerd dat hieruit zo min mogelijk inspanningen en gevolgen voortkomen voor overheden, burgers en economische sectoren. Er is bijvoorbeeld rekening gehouden met bestaande plannen en projecten ter realisering van de NNN. Het doelendocument verwacht dat in beheerplannen de afweging tussen natuur en economie gemaakt wordt.

\section{Aanwijzingsbes/uiten}

Bij elk ontwerp-aanwijzingsbesluit vindt een inspraakprocedure plaats op grond van de Algemene wet bestuursrecht. Het (definitieve) aanwijzingsbesluit volgt na afloop van de openbare procedure. Belanghebbenden kunnen een zienswijze indienen en eventueel daaropvolgend in beroep gaan bij de Raad van State als ze het niet eens zijn met het (definitieve) aanwijzingsbesluit (Programmadirectie Natura 2000, 2014). 


\section{Beheerplannen}

In de checklist beheerplannen (zie paragraaf 2.4.3.) staat dat de financiële consequenties van de maatregelen en de sociaaleconomische consequenties betreffende huidige en toekomstige activiteiten duidelijk beschreven dienen te worden. In 74 procent van de geëvalueerde beheerplannen wordt er in de sociaaleconomische paragraaf concreet uitgewerkt welke sociaaleconomische gevolgen er zijn of worden verwacht in het betreffende Natura 2000-gebied of wordt er aangegeven dat een dergelijke analyse niet nodig is (Figuur 13). Dit laatste wordt geconcludeerd in het Algemeen Deel rapport voor de beheerplannen van de Deltawateren. De beheerplannen die hiervan zijn geëvalueerd, betreffen de gebieden Oude Maas, Hollands Diep, Veerse Meer en Voordelta. In het Algemeen Deel rapport wordt toegelicht dat Rijkswaterstaat als voortouwnemer in het gebiedsproces in goed overleg met (vertegenwoordigers van) betrokkenen vorm heeft gegeven aan de mitigerende maatregelen en voorwaarden die aan de activiteiten in de Deltawateren verbonden moeten worden. Men beschrijft dat het dankzij deze aanpak niet noodzakelijk was een diepgaande sociaaleconomische analyse uit te voeren in bijvoorbeeld de vorm van een maatschappelijke kosten-batenanalyse (dit conform de notitie 'Beheerplannen Natura 2000: Sociaaleconomische gevolgen en ontwikkelingsruimte' van het Regiebureau Natura 2000). In één beheerplan ontbreekt de sociaaleconomische paragraaf, zonder opgaaf van reden. Van de overige 9 beheerplannen zonder gebiedsspecifieke analyse zijn er 7 beheerplannen van voortouwnemer Provincie Overijssel. De tekst in deze beheerplannen is voor ieder plan hetzelfde en gebiedsspecifieke toelichting ontbreekt. In deze beheerplannen worden de resultaten van een provinciaal onderzoek naar de sociaaleconomische effecten van de PAS-maatregelen besproken. De resultaten geven aan dat de positieve effecten op provinciale en regionale schaal groter zijn dan de negatieve effecten die plaatselijk optreden. Welke negatieve effecten dit specifiek per gebied zijn, wordt niet benoemd.

\section{De uitwerking van de sociaaleconomische analyse in de}

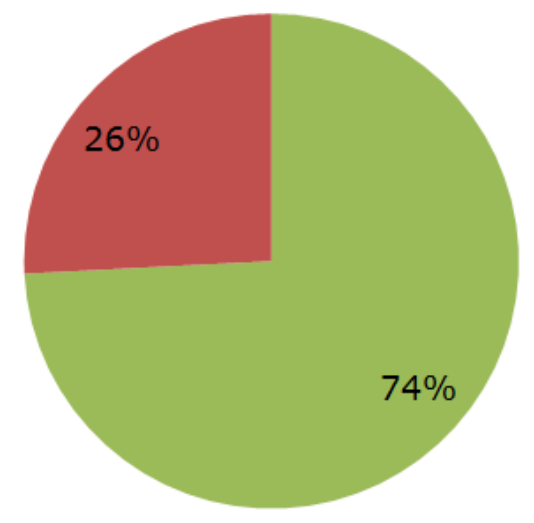

De beheerplannen met gebiedsspecifieke sociaaleconomische analyse of waarin wordt onderbouwd dat deze niet nodig is.

De beheerplannen zonder sociaaleconomische paragraaf of zonder gebiedsspecifieke analyse.

Figuur 13 De mate waarin de sociaaleconomische analyse in de beheerplannen $(n=31)$ op gebiedsniveau is uitgewerkt.

\subsubsection{Realistisch}

\subsubsection{Definitie}

Met realistisch wordt door de Europese Commissie (2012) bedoeld dat de instandhoudingsdoelen binnen een aannemelijke tijdsperiode en met beschikbare middelen te realiseren zijn.

Be realistic - given a reasonable time-frame and application of resources (Europese Commissie, 2012). 


\subsubsection{Motivatie}

Indien doelen niet realistisch zijn, heeft dit consequenties voor het politiek-bestuurlijk en maatschappelijk draagvlak.

\subsubsection{Toepassing}

Natura 2000-doelendocument

In het Natura 2000-document is realistisch verwoord via de hoofdlijnen Haalbaar en betaalbaar en Passend binnen bestaande budgetten (zie paragraaf 2.1.1 en Tabel 2). Ook hier is invulling aan gegeven via het principe van strategisch lokaliseren. Er is een kostenraming gemaakt voor de te nemen maatregelen.

Aanwijzingsbes/uiten

Deze voorwaarde komt niet expliciet aan de orde in de aanwijzingsbesluiten.

\section{Beheerplannen}

Haalbaar en betaalbaar zijn als voorwaarde gesteld aan de maatregelen (niet aan de doelen) in de checklist beheerplannen. Er is door het Rijk en provincies in 2009 afgesproken om de eerste beheerplanperiode te richten op behoudsopgaven, hetgeen niet zonder meer wil zeggen dat die ook haalbaar zijn. Dit criterium is niet getoetst, want hoe dit objectief te toetsen? Dat vergt een vrij uitgebreide analyse, zoals bij de haalbaarheid van landelijke doelen of referentiewaarden is uitgevoerd (Bijlsma et al., 2014; Foppen et al., 2016), hetgeen niet paste binnen het budget en de tijd binnen dit onderzoek.

\subsubsection{Tijdgebonden}

\subsubsection{Definitie}

Tijdgebonden houdt in dat er een termijn wordt gesteld aan de realisatie van de doelen. Aan de doelen van de VR en HR is geen termijn verbonden. Ook het Rijk stelt dit niet als voorwaarde. Er mag van de EC echter geen verslechtering plaatsvinden, hetgeen betekent dat er wel een termijn verbonden is aan de maatregelen om een mogelijke verslechtering tegen te gaan.

\subsubsection{Motivatie}

Indien er geen termijn wordt verbonden aan doelen en/of maatregelen is het tempo van de realisatie van de doelen vrijblijvend. Dit betekent dat er niet tijdig kan worden ingegrepen ofwel bijgestuurd en er een onomkeerbare situatie kan ontstaan.

\subsubsection{Toepassing}

\section{Natura 2000-doelendocument}

Het Natura 2000-doelendocument heeft een termijn gesteld aan de SoU-maatregelen, maar niet aan de instandhoudingsdoelen. Verwacht wordt dat de doelen in de beheerplannen nader uitgewerkt worden in omvang, ruimte en tijd (en kwaliteit).

\section{Aanwijzingsbes/uiten}

Er wordt geen termijn verbonden aan de doelen in de aanwijzingsbesluiten.

\section{Beheerplannen}

In 90,3 procent van de geëvalueerde beheerplannen wordt aangegeven op welke termijn men de doelen wil realiseren (Figuur 14). De termijnplanning wordt in termen uitgedrukt van beheerplanperioden (bpp). In de beheerplannen wordt de termijnplanning vaak op dezelfde manier verwoord, namelijk dat de herstelmaatregelen op korte termijn (1e bpp) zijn gericht op het voorkomen van verslechtering van de aangewezen instandhoudingsdoelstellingen ofwel behoudsopgaven, zoals ook door Rijk en provincies is afgesproken in 2009. Op de lange termijn ( $2^{\mathrm{e}}$ en $3^{\mathrm{e}} \mathrm{bpp}$ ) worden oppervlakte-uitbreiding en kwaliteitsverbetering (indien tot doel gesteld voor de aangewezen habitattypen/leefgebieden) gerealiseerd conform de afspraken tussen Rijk en provincies. 


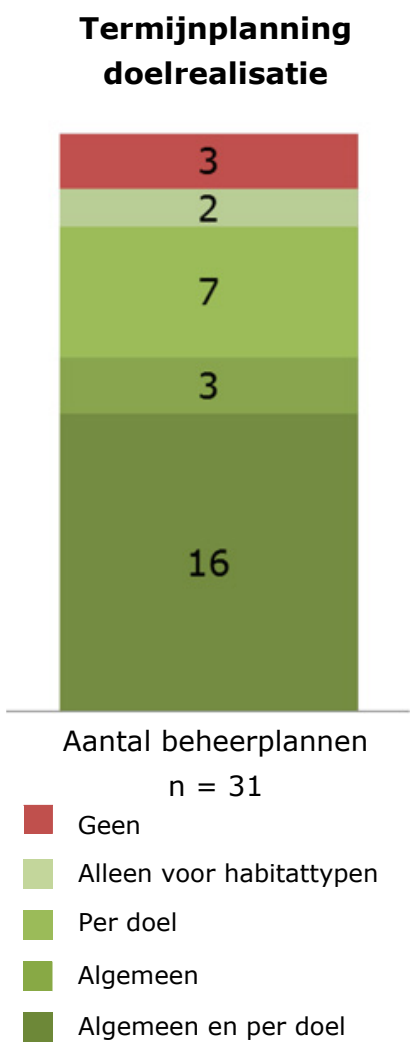

Figuur 14 Het aantal beheerplannen waarin wordt aangegeven op welke termijn men de doelen wil realiseren.

\subsubsection{Consistent}

\subsubsection{Definitie}

Met consistent wordt door de Europese Commissie bedoeld dat de instandhoudingsdoelen op een vergelijkbare wijze geformuleerd worden, zodat vergelijking mogelijk is tussen de landelijke doelen en gebiedsdoelen en de gebiedsdoelen onderling.

Be consistent in approach - the structure of conservation objectives should, as far as is possible, be the same across all (UK Natura 2000) marine sites, and at sites supporting the same interest feature, use similar attributes and targets to describe favourable condition (Europese Commissie, 2012).

\subsubsection{Motivatie}

Indien doelen niet consistent zijn geformuleerd, is de vergelijking tussen de landelijk doelen en de gebiedsdoelen en tussen de gebiedsdoelen lastig zo niet onmogelijk, hetgeen van belang is voor het bewaken van de samenhang of wel interne coherentie (zie onder interne coherentie).

\subsubsection{Toepassing}

\section{Natura 2000-doelendocument}

In het Natura 2000-doelendocument is consistentie niet als voorwaarde gesteld. Doelen zijn wel consistent geformuleerd in de zin dat er per soort en per habitattypen en per aspect van de staat van instandhouding - met uitzondering van het toekomstperspectief ${ }^{4}$ - doelen zijn geformuleerd. Dezelfde structuur is gevolgd bij de nadere uitwerking van de doelen in de beheerplannen. Daarbij is wel op een

\footnotetext{
4 Het lijkt logisch om geen doel te stellen ten aanzien van het toekomstperspectief, maar dit aspect van de staat van instandhouding van soorten en habitattypen wordt naast de trends ook beoordeeld op basis van de (verwachte) effecten van drukfactoren en bedreigingen. Hier zou men in principe wel doelen voor kunnen formuleren, bijvoorbeeld vermindering van stikstofdepositie.
} 
verschillende wijze invulling gegeven aan de nadere uitwerking of concretisering van de doelen, vooral wat betreft de kwaliteitsdoelen (zie onder meetbaarheid).

Aanwijzingsbes/uiten

In de aanwijzingsbesluiten zijn de doelen op dezelfde manier geformuleerd als in het Natura 2000doelendocument.

\section{Beheerplannen}

De doelen uit de aanwijzingsbesluiten worden overgenomen in de beheerplannen. De uitwerking in omvang, ruimte en tijd (en kwaliteit) is divers (zie onder meetbaar) en daardoor niet consistent.

\subsubsection{Alomvattend}

\subsubsection{Definitie}

Met alomvattend wordt door de Europese Commissie bedoeld dat de instandhoudingsdoelen alle aspecten omvatten die nodig zijn om de status van een soort en habitattype als gunstig of ongunstig te kunnen beoordelen.

Be comprehensive - the attributes and targets should cover the properties of the interest feature necessary to describe its condition as either favourable or unfavourable (Europese Commissie, 2012).

\subsubsection{Motivatie}

Indien de doelen niet alomvattend zijn geformuleerd, kan ook niet goed worden beoordeeld of een doel is bereikt en kan niet goed worden bijgestuurd.

\subsubsection{Toepassing}

Natura 2000-doelendocument

In het Natura 2000-doelendocument is alomvattend niet als voorwaarde opgenomen. De doelen zijn wel alomvattend geformuleerd in de zin dat er voor alle soorten (met uitzondering van Annex IV en V) en habitattypen en alle relevante aspecten van de staat van instandhouding - met uitzondering van toekomstperspectief ${ }^{5}$ - behoud- en herstelopgaven zijn geformuleerd.

Aanwijzingsbes/uiten

In de aanwijzingsbesluiten zijn de doelen op dezelfde manier geformuleerd als in het Natura 2000doelendocument.

\section{Beheerplannen}

De doelen uit de aanwijzingsbesluiten worden overgenomen in de beheerplannen. De uitwerking in omvang, ruimte en tijd (en kwaliteit) is divers (zie onder meetbaar).

\subsubsection{Robuust}

\subsubsection{Definitie}

Robuust heeft ermee te maken of men bij de doelformulering rekening houdt met toekomstige ontwikkelingen door onder meer natuurlijke dynamiek en klimaatverandering. Hierbij speelt de afweging of doelen 'toekomstbestendig' zijn, oftewel ook op langere termijn realiseerbaar zijn.

\subsubsection{Motivatie}

Indien doelen niet robuust zijn, betekent dit dat ze op lange termijn niet haalbaar zijn en/of dat er zeer hoge budgetten nodig zijn voor het realiseren van deze doelen.

\footnotetext{
5 Het is lastig om een doel te stellen t.a.v. het toekomstperspectief. Men zou wel doelen kunnen stellen t.a.v. maatregelen om de effecten van drukfactoren en bedreigingen in de toekomst tegen te verminderen dan wel te voorkomen.
} 


\subsubsection{Toepassing}

Natura 2000-doelendocument

In het Natura 2000-doelendocument is robuust verwoord onder een van de acht hoofdlijnen, te weten "anticiperend op natuurlijke dynamiek en klimaatverandering". Instandhoudingsdoelen zijn geformuleerd voor afzonderlijke soorten en habitattypen, maar ook voor samenhangende landschappen of systemen (zie paragraaf 2.1.2). Elk van de Natura 2000-landschappen heeft in meer of mindere mate, ten gevolge van de historie van de bescherming van gebieden en de aard van de ligging in het omringende landschap, eigen specifieke processen en daarmee verschillende 'knoppen' waar aan gedraaid kan worden om een meer duurzame bescherming van de gebieden en een meer gunstige staat van instandhouding van de voor het landschap specifieke habitattypen en soorten te garanderen.

\section{Aanwijzingsbes/uiten}

In de aanwijzingsbesluiten (hoofdstuk 3) worden de landschappelijke context en de natuurlijke kenmerken beknopt beschreven.

\section{Beheerplannen}

In de checklist beheerplannen staat dat de beschrijving van de natuurwaarden ecologisch moet worden onderbouwd door middel van een landschapsecologische systeemanalyse conform het Werkkader Landschapsecologische Systeemanalyse, waarbij de koppeling gelegd wordt tussen biotiek en abiotiek. Het is in dit project niet nader onderzocht of dat inderdaad ook het geval is.

\subsubsection{Flexibel}

\subsubsection{Definitie}

Onder flexibel wordt hier verstaan, conform de principes van het Natura 2000-doelendocument, dat er ruimte wordt gelaten voor een nadere uitwerking in omvang, ruimte, tijd (en kwaliteit) van de instandhoudingsdoelen op regionaal en/of gebiedsniveau.

Het begrip flexibiliteit komt in het kader van de Fitness Check van de EC (Broekmeijer et al., 2015) herhaaldelijk naar voren en wordt daar anders geïnterpreteerd. Daar wordt door de geïnterviewde stakeholders de wens geuit om de doelen niet op specifieke habitattypen en soorten te richten en ook niet te lokaliseren binnen de Natura 2000-gebieden, zodat er gemakkelijker gesaldeerd kan worden en er meer ruimte kan worden geboden aan bijvoorbeeld economische ontwikkelingen. Dit is overeenkomstig de uitgangspunten van de Rijksnatuurvisie 2014. In dit onderzoek is de invalshoek van het Natura 2000-doelendocument gevolgd, aangezien dat ook het vertrekpunt is van dit onderzoek (zie hoofdstuk 2).

\subsubsection{Motivatie}

In het Natura 2000-doelendocument wordt het criterium flexibel als zodanig niet genoemd, maar wel wordt het impliciet verwoord in een van de twee principes, te weten de balans tussen richting geven en ruimte laten (zie Tabel 2). Met deze benaderingswijze wordt ruimte geboden om bij voortschrijdend inzicht, nieuwe kennis etc. aanpassingen in het realiseringstempo of de aard van de maatregelen aan te brengen.

\subsubsection{Toepassing}

\section{Natura 2000-doelendocument}

In het Natura 2000-doelendocument betreft dit dus een van de twee principes, te weten de balans tussen richting geven en ruimte laten (zie paragraaf 2.1.1 en Tabel 2). De ruimte voor de voortouwnemers is echter beperkt. In de aanwijzingsbesluiten zijn de doelen tenslotte al vastgelegd (veelal voordat het Natura 2000-doelendocument is uitgebracht), namelijk welke habitattypen en soorten in de Natura 2000-gebieden behouden of hersteld dienen te worden. De ruimte die wordt geboden, zit hem vooral in de temporisering (paragraaf 3.3.8) en de lokalisering van de Natura 2000doelen en bijvoorbeeld niet in de selectie van habitattypen en soorten. 


\section{Aanwijzingsbes/uiten}

In de toelichting op de aanwijzingsbesluiten staat vermeld dat er naast de Natura 2000-waarden het gebied ook natuurwaarden omvat die integraal onderdeel uitmaken van de ecosystemen waartoe de aangewezen (leefgebieden van) soorten en habitattypen behoren, alsmede natuurwaarden waarvan het behoud en belangrijke bijdrage levert aan het behalen van de landelijke gunstige staat van instandhouding (Programmadirectie Natura 2000, 2014). Hiermee wordt dus gedoeld op een ruimere invulling van de natuuropgaven dan de Natura 2000-doelen, waarmee eventueel ook geanticipeerd kan worden op andere maatschappelijke opgaven.

Bijlsma et al. (2016) gaan hier bij de nadere invulling van robuuste natuurdoelen op in, in die zin dat de Natura 2000-doelen gebaseerd en onderbouwd zouden moeten worden op/met systeemvisie met daaraan ten grondslag een landschapsecologische systeemanalyse. Juist door de combinatie van Natura 2000-doelen met andere natuurdoelen (en eventueel ook andere maatschappelijk opgaven zoals wateropgaven) kan meer ecologische en bestuurlijke ruimte gecreëerd worden, is zijn stelling. Bijlsma (2016) maakt daarbij onderscheid tussen kwetsbare, karakteristieke en niet-karakteristieke natuurwaarden. De laatste categorie past niet in de systeemvisie en kan mogelijk een huidig Natura 2000-doel zijn, maar zou dan op termijn geschrapt kunnen worden. De vraag is of dat juridisch stand houdt.

\section{Beheerplannen}

In de checklist beheerplannen is vermeld dat er ook andere natuurwaarden dan de instandhoudingsdoelen van de Vogelrichtlijn en de Habitatrichtlijn mogen worden vermeld. Hiermee zou dus naar voorbeeld van Bijlsma et al. (2016) meer ruimte gecreëerd kunnen worden door de Natura 2000-doelen die niet passen in de systeemvisie (gebaseerd op een landschapsecologische systeemanalyse) als niet-karakteristiek te bestempelen en op termijn te schrappen.

De 31 geëvalueerde gebieden omvatten samen 473 instandhoudingsdoelstellingen. Bij 97,5 procent van de instandhoudingsdoelstellingen wordt gestreefd naar realisering van de instandhoudingsdoelstellingen, zoals vastgesteld in het aanwijzingsbesluit. Bij 2,1 procent van de instandhoudingsdoelstellingen wordt aangegeven dat men meer inspanning wil leveren dan nodig is om de instandhoudingsdoelstelling te behalen. Het gaat om 10 instandhoudingsdoelstellingen: 4 habitattypen in Solleveld \& Kapittelduinen, 3 habitattypen in Duinen Goeree \& Kwade Hoek, 2 habitattypen in Westduinpark \& Wapendal en 1 habitattype in Voornes Duin. Er is voor één instandhoudingsdoelstelling aangegeven dat men bewust een lagere populatieomvang nastreeft dan is vastgesteld in het aanwijzingsbesluit. Het gaat hierbij om een conflicterende situatie tussen de lepelaar en de aalscholver in Voornes Duin, waarbij besloten is om de lepelaar prioriteit te geven boven de aalscholver.

In 10 van de 31 geëvalueerde beheerplannen (32 procent) wordt gesproken over andere natuurdoelen. In één daarvan wordt aangegeven dat men zich wil inzetten voor de regiodoelstelling van een soort, hoewel er voor deze soort geen specifieke doelstelling in het gebied zelf geldt. Er wordt geen kwantitatief doel gesteld voor deze aanvullende natuurwaarde. In vier beheerplannen wordt als overige natuurwaarde gesproken over de 'oude doelen' van de beschermde natuurmonumenten. Alleen in beheerplannen Westduinpark \& Wapendal en Solleveld \& Kapittelduinen van provincie ZuidHolland worden deze doelen expliciet vertaald naar kwantitatieve doelen (zie toelichting Westduinpark \& Wapendal in kader op volgende pagina). In het beheerplan Lepelaarplassen wordt geconcludeerd dat er voor de 'oude doelen' van de beschermde natuurmonumenten van de Lepelaarplassen geen aanvullende opgave voor het beheerplan is, omdat deze meeliften op maatregelen die genomen worden voor de Natura 2000-instandhoudingsdoelen. Bij de andere beheerplannen wordt vaak het voorkomen van bepaalde andere (niet Natura 2000) natuurwaarden besproken en vermeld dat de genoemde natuurdoelen kunnen meeliften op maatregelen die genomen worden voor de Natura 2000instandhoudingsdoelen, of dat er bij het opstellen van het maatregelenpakket rekening is gehouden met deze waarden. In deze beheerplannen worden geen kwantitatieve doelen gesteld voor deze aanvullende natuurwaarden. Er zijn zeven beheerplannen waar onduidelijk is of er sprake is van andere doelen. Zes van deze beheerplannen zijn van voortouwnemer Provincie Overijssel. In deze beheerplannen wordt benoemd dat er een aantal habitattypen in het gebied voorkomen die niet in het aanwijzingsbesluit zijn opgenomen. Men geeft aan dat bij het beheer en de uitvoering van de maatregelen rekening moet worden gehouden met de aanwezigheid van deze habitattypen. Deze 
habitattypen komen echter verder niet meer ter sprake in het beheerplan. Of (en zo ja, hoe) men met de uitvoering van de maatregelen rekening heeft gehouden met deze habitattypen is daarom onduidelijk. Het andere beheerplan betreft er één van voortouwnemer EZ. Hierin wordt beschreven dat er ook andere doelen zijn dan Natura 2000, maar welke dit zijn, wordt niet toegelicht en deze doelen worden ook niet verder uitgewerkt in het beheerplan.

In 6 van de 31 geëvalueerde gebieden waren oorspronkelijk voor een of meer (vogel)soorten en/of habitattypen complementaire doelen geformuleerd. In 3 van deze gebieden is in het beheerplan over deze complementaire doelen gesproken. Men geeft aan dat de complementaire doelen zijn komen te vervallen en dat er daarom in het beheerplan geen expliciete maatregelen worden opgenomen voor deze doelen. Er wordt aangegeven dat sommige complementaire doelen wel kunnen profiteren van maatregelen die voor andere instandhoudingsdoelstellingen of in het kader van ander beleid worden genomen.

\subsection{Conclusies en aanbevelingen}

\subsubsection{Conclusies}

In de onderstaande paragrafen worden, mede op basis van de resultaten die zijn samengevat in Tabel 4, conclusies getrokken en aanbevelingen gedaan.

\subsubsection{De voorwaarden die door de EC en het Rijk gesteld worden aan de formulering van de Natura 2000-doelen en motivatie}

De voorwaarden die het Rijk stelt aan de formulering van de Natura 2000-doelen in het Natura 2000doelendocument zijn grotendeels in lijn met de voorwaarden die de Europese Commissie (EC) hieraan stelt (zie Tabel 2). Belangrijke overeenkomstige voorwaarden zijn:

- coherentie intern

- prioritering

Deze voorwaarden zijn van belang voor besluitvorming over in te zetten middelen en uit te voeren maatregelen en te verwachten resultaat, ofwel voor een doelmatig en doeltreffend beleid. Bovendien moet worden voorkomen dat verslechtering van de staat van instandhouding van habitattypen en soorten optreedt.

De voorwaarden die het Rijk stelt aan de formulering van de Natura 2000-doelen in het Natura 2000doelendocument zijn grotendeels in lijn met de Rijknatuurvisie 2014 (zie Tabel 2). Belangrijke overeenkomstige voorwaarden zijn:

- Coherentie met ander beleid

- Acceptabel

- Robuust

- Flexibel

Deze voorwaarden zijn van belang voor politiek-bestuurlijk en maatschappelijk draagvlak en voor een doelmatig en doeltreffend beleid. De Rijksnatuurvisie 2014 heeft echter een veel bredere context dan de Europese Vogel- en Habitatrichtlijn. De Vogelrichtlijn en Habitatrichtlijn hebben als primair doel de instandhouding van soorten en habitattypen, waarbij rekening wordt gehouden met sociaaleconomische belangen, maar waarbij niet expliciet wordt gezocht naar combinaties van natuuropgaven en andere maatschappelijk opgaven (bv. economische ontwikkeling). De voorwaarden robuust en flexibel worden op verschillende wijze geïnterpreteerd. In dit onderzoek is de invulling van het Natura 2000-doelendocument gevolgd, maar deze komt niet overeen met die van de Fitness Check (Broekmeijer et al., 2016), zie paragraaf 3.3.12. 
De Europese Commissie heeft een notitie opgesteld over de formulering van de Natura 2000-doelen, die een aantal jaren na de publicatie van het Natura 2000-doelendocument in 2012 is gepubliceerd. Hierin komen een aantal voorwaarden aan de orde, die niet direct terug te vinden zijn in het Natura 2000-doelendocument, te weten:

- specifiek

- meetbaar

- realistisch (vgl. met haalbaar en betaalbaar)

- consistent

- alomvattend

Dit is te verklaren uit het feit dat er in het Natura 2000-doelendocument van uit wordt gegaan dat de nadere uitwerking van de Natura 2000-doelen in omvang, ruimte en tijd (en kwaliteit) in de beheerplannen plaatsvindt. In de checklist beheerplannen komen deze voorwaarden - weliswaar in andere bewoordingen - wel aan de orde, want er wordt onder de paragraaf instandhoudingsdoelen gevraagd naar de formulering van 'concrete en toetsbare' doelen. Deze voorwaarden zijn van belang voor de monitoring en evaluatie van de Natura 2000-doelen (mate van doelbereik) en daarmee voor de sturing van beleid. De doelen t.a.v. de populatiegrootte van VR-soorten zijn in 2006 ook op landelijk niveau al gekwantificeerd. Voor de HR-soorten en habitattypen zijn pas later referentiewaarden vastgesteld voor de verspreiding en populatiegrootte van HR-soorten (Ottburg en Van Swaaij, 2014) en de verspreiding en oppervlakte van habitattypen (Bijlsma et al., 2014a).

Een voorwaarde die door de Europese Commissie en het Rijk niet expliciet aan de formulering van de Natura 2000-doelen wordt gesteld, is tijdsgebondenheid. Indirect is dat echter wel het geval, aangezien de staat van instandhouding van soorten en habitattypen niet mag verslechteren (voor HR-gebieden vanaf 7 december 1994 en voor de VR-gebieden afhankelijk van de datum van de aanwijzing die uiterlijk terug kan gaan tot 10 juni 1994) en er dus tijdig maatregelen genomen moeten worden om dit te voorkomen. In de checklist beheerplannen wordt wel naar een termijn gevraagd voor het nemen van maatregelen. Deze voorwaarde is van belang om tijdig in te kunnen grijpen en te voorkomen dat er verslechtering plaatsvindt, dus in feite ook voor de sturing van beleid.

\subsubsection{Wijze waarop wordt wel/niet invulling wordt gegeven de voorwaarden aan de formulering van de Natura 2000-doelen}

Hoe goed invulling is gegeven aan de door de EC en het Rijk gestelde voorwaarden in respectievelijk het Natura 2000-doelendocument, de aanwijzingsbesluiten en de beheerplannen is lastig te beoordelen, aangezien de achterliggende analyses (bv. de toetsing van de haalbaarheid en betaalbaarheid van de Natura 2000-doelen) niet altijd toegankelijk zijn. Men stelt dus bepaalde voorwaarden, maar de toetsing ervan ontbreekt.

Ook uit de inventarisatie van de (31) beheerplannen kan niet goed worden opgemaakt hoe er invulling is gegeven aan de voorwaarden (zie Tabel 4), bijvoorbeeld wat betreft de samenhang tussen gebiedsdoelen en landelijke doelen (interne coherentie), de afstemming met andere beleidsdoelen (coherentie met ander beleid) en de prioritering van doelen (zie voor details Vreeswijk et al., 2016).

Wel kan geconcludeerd worden dat de doelen t.a.v. 'kwaliteit' (de kwaliteit van het leefgebied van soorten en de kwaliteit van habitattypen) in tegenstelling tot de doelen t.a.v. kwantiteit (de populatiegrootte van soorten en het oppervlakte van habitattype) in veel gevallen niet SMART en daarmee ook niet toetsbaar zijn geformuleerd. De wijze waarop de doelen t.a.v. kwaliteit zijn uitgewerkt, verschilt sterk tussen de beheerplannen.

\subsubsection{Mogelijke oorzaken van het niet voldoen aan de voorwaarden de gesteld worden aan de formulering van de Natura 2000-doelen}

Het niet voldoen aan de voorwaarden voor de formulering van de Natura 2000-doelen is te verklaren door enerzijds politiek-bestuurlijke factoren en anderzijds door de hiaten in de kennis en informatievoorziening en onduidelijkheden over de voorschriften van de EC en het Rijk. Zo vereist coherentie en prioritering van doelen een goede samenwerking tussen overheden op verschillende bestuurlijke niveaus en met private en maatschappelijke organisaties en vereist de toetsbare formulering van de doelen duidelijke instructies en de beschikbaarheid van gegevens en kennis. 
Een andere mogelijke oorzaak lig bij de financiering en aansturing van de uitvoering van de maatregelen. Zo loopt de financiering van de beheermaatregelen grotendeels via het Subsidiestelsel Natuur en Landschapsbeheer (SNL) en het Agrarisch Natuur en Landschapsbeheer (ANLb). Het SNL is gestoeld op de index NL (de natuurbeheertypen). De terreinbeherende organisaties sturen hun beheercyclus dan ook aan op basis van dit stelsel. Watermaatregelen worden veelal via de Kaderrichtlijn Water (KRW) gefinancierd. De relatie met desbetreffende dossiers (SNL, ANLb en KRW) wordt in de beheerplannen vaak genoemd, maar veelal niet expliciet gemaakt (zie Vreeswijk et al., 2016). De vraag is dan ook of het beheerplan daadwerkelijk de functie vervult zoals beoogd wordt (zie paragraaf 2.2.1).

De Natura 2000-doelen zijn gericht op een selectie van soorten (voor VR-soorten uitgebreider dan voor HR-soorten) en op specifieke habitattypen. Voor het beheer van een gebied moet echter rekening gehouden worden met het totale gebied oftewel het hele ecosysteem (ecosysteembenadering). In de beheerplannen lijkt dit echter niet echt tot zijn recht te komen, aangezien er zelden aanvullende (natuur)doelen worden genoemd. Het is dan ook niet duidelijk of er sprake is van coherentie tussen verschillende natuurdoelen. Ook hier kan weer de vraag gesteld worden of het beheerplan ook daadwerkelijk de functie vervult zoals wordt beoogd.

\subsubsection{Mogelijke consequenties van het niet voldoen aan de voorwaarden die gesteld worden aan de Natura 2000-doelen}

De consequenties van het niet voldoen aan de formulering van de Natura 2000-doelen gestelde voorwaarden zijn onder meer incoherentie en gebrek aan prioritering en sturing met als gevolg een ondoelmatig en ondoeltreffend beleid. Dit kan echter niet zonder meer worden geconstateerd op basis van dit onderzoek, omdat de informatie hierover veelal ontbreekt in de beheerplannen.

\subsubsection{Aanbevelingen}

\subsubsection{Eenduidige interpretatie en beleidsmatige onderbouwing van de voorwaarden aan doelformulering}

In dit onderzoek is op basis van verschillende achtergronddocumenten een toetsingskader opgesteld voor de analyse van de Natura 2000-doelensystematiek (zie paragraaf 3.2). Daaruit is gebleken dat de interpretatie van bepaalde voorwaarden aan de doelformulering van de EC en het Rijk, bijvoorbeeld 'robuust' en 'flexibel', varieert. Dit terwijl er verwachtingen zijn dat de Natura 2000-doelensystematiek op deze punten verbeterd kan worden, hetgeen zou leiden tot een doelmatiger en doeltreffender Natura 2000-beleid (Broekmeijer et al., 2016). Aanbevolen wordt om op basis van het huidige toetsingskader tot een eenduidige interpretatie te komen van voorwaarden aan de doelformulering en deze goed te onderbouwen met een beleidstheorie.

\subsubsection{Functie beheerplannen herbezien}

Uit de beheerplannen van de Natura 2000-gebieden kan niet goed worden op gemaakt of, en zo ja in hoeverre, de Natura 2000-opgaven samenhangen met andere maatschappelijke (natuur)opgaven. Zo is de samenhang tussen de Natura 2000-doelen en de ambities van het Nederlands Natuurnetwerk (NNN) en het Subsidiestelsel Natuur en Landschap (SNL) onduidelijk (zie paragraaf 3.3.12). De vraag is of het beheerplan van Natura 2000-gebieden hier wel het instrument voor is. Bijlsma et al. (2016) komen met een advies over een op een systeemvisie gebaseerde doelformulering, waarbij naast Natura 2000-waarden ook andere natuurwaarden worden meegewogen en niet-karakteristieke doelen (niet bij het systeem passende) worden verlaten (ook de Natura 2000-waarden). In principe worden de gebiedsdoelen in de aanwijzingsbesluiten al vastgelegd, dit qua selectie van gebieden voor specifieke soorten en habitattypen en de behoud- en herstelopgaven voor desbetreffende soorten en habitattypen. Dat betekent dat de ruimte, ofwel flexibiliteit voor nadere invulling van de natuurdoelen door de voortouwnemers bij het opstellen van de beheerplannen beperkt is.

\subsubsection{Voorschriften voor monitoring en beoordeling Natura 2000-doelen verbeteren} De huidige voorschriften voor de monitoring en beoordeling van de Natura 2000-doelen, vooral wat betreft de doelen ten aanzien van de kwaliteit van habitattypen en leefgebieden van soorten, bieden kennelijk nog onvoldoende houvast voor de opstellers van de beheerplannen om de gebiedsdoelen SMART te formuleren. Het is aan te bevelen om deze voorschriften nader uit te werken. Vreeswijk van et al. (2016) geven suggesties hoe de checklist voor het opstellen van beheerplannen te verbeteren. 


\subsubsection{Gegevens- en informatievoorziening verbeteren}

Om de Natura 2000-doelen SMART te formuleren, zijn gegevens nodig van een goede kwaliteit (actueel, volledig, juist etc.). Deze zijn niet altijd beschikbaar. Het is aan te raden om de huidige gegevens- en informatievoorziening te verbeteren.

Tabel 4 Samenvatting resultaten toetsing Natura 2000-doelensystematiek.

\begin{tabular}{|c|c|}
\hline $\begin{array}{l}\text { Toetsings- } \\
\text { criteria }\end{array}$ & Conclusies \\
\hline $\begin{array}{l}\text { Coherentie } \\
\text { intern }\end{array}$ & $\begin{array}{l}\text { De samenhang tussen doelen op EU, nationaal, regionaal en gebiedsniveau wordt in Nederland geborgd } \\
\text { door bij het formuleren van de Natura 2000-doelen rekening te houden met op landelijk niveau het } \\
\text { relatieve belang van Nederland voor de EU en op gebiedsniveau het relatieve belang van het } \\
\text { Natura } 2000 \text {-gebied voor Nederland. Het relatieve belang van een Natura 2000-gebied wordt } \\
\text { beoordeeld in het Standard Data Form (SDF's) en gerapporteerd naar de EC. In Nederland zijn er uit het } \\
\text { principe van strategisch lokaliseren ook kernopgaven per Natura 2000-landschap geformuleerd, } \\
\text { die vervolgens zijn toebedeeld aan de Natura 2000-gebieden. } \\
\text { In de checklist van de beheerplannen wordt onder de paragraaf instandhoudingsdoelen gevraagd om } \\
\text { rekening te houden met de relatieve bijdrage van het Natura 2000-gebied (checkpunt 16) en om ook de } \\
\text { kernopgaven uit het Natura 2000-doelendocument over te nemen (checkpunt 10). Deze informatie is } \\
\text { echter niet altijd in de beheerplannen terug te vinden en in het geval men deze informatie wel heeft } \\
\text { overgenomen, wordt er vaak niet toegelicht wat men hier voor gevolg aan geeft. }\end{array}$ \\
\hline $\begin{array}{l}\text { Coherentie } \\
\text { ander beleid }\end{array}$ & $\begin{array}{l}\text { De samenhang tussen het Natura 2000-beleid en het water- en stikstofbeleid wordt geborgd via de } \\
\text { Kaderrichtlijnwater en de Programmatische Aanpak Stikstof. Bovendien wordt het Natura 2000- } \\
\text { beleid ook afgestemd op de het Natuurnetwerk Nederland (NNN) en daarmee samenhangend het } \\
\text { Subsidiestelsel Natuur- en Landschapsbeheer (SNL) en het Agrarisch Natuur en } \\
\text { Landschapsbeheer (ANLB) en het soortenbeleid. } \\
\text { In de checklist beheerplannen wordt gevraagd een waterparagraaf (checkpunt 31-34), een } \\
\text { stikstofparagraaf (checkpunt 35-38) en een paragraaf bestaand beleid en wet- en regelgeving } \\
\text { (27-28) op te nemen. In de beheerplannen wordt in de betreffende paragrafen echter veelal niet duidelijk } \\
\text { toegelicht en onderbouwd welke maatregelen gerelateerd aan de genoemde dossiers genomen gaan } \\
\text { worden om de Natura 2000-doelen - in combinatie met andere doelen - te realiseren. }\end{array}$ \\
\hline
\end{tabular}

Prioritering De prioritering voor de realisatie van een gunstige staat van instandhouding van bepaalde soorten en habitattypen (of ten minste behoud van de huidige staat) is toegepast op basis van de Sense of Urgency-opgaven en -maatregelen.

In de checklist beheerplannen wordt gevraagd onder de paragraaf maatregelen (checkpunt 24-26) om aan te geven wat de grootste knelpunten en belangrijkste maatregelen zijn om de doelen te realiseren. Ook wordt aangegeven dat de SoU-maatregelen gedurende de $1^{\mathrm{e}}$ beheerplanperiode genomen dienen te worden. In de beheerplannen wordt veelal wel melding gemaakt van de SoU-opgaven mits van toepassing, maar wordt veelal niet duidelijk beschreven welke nadere invulling men hieraan geeft.

Specifiek De Natura 2000-doelen zijn specifiek in de zin dat er doelen zijn geformuleerd voor specifieke soorten en habitattypen en specifieke aspecten van de staat van instandhouding (populatiegrootte, oppervlakte en kwaliteit leefgebied en habitattype). Voor de doelen t.a.v. kwantiteit (verspreiding, populatiegrootte en oppervlakte) zijn landelijke referentiewaarden vastgesteld. Dit zijn drempelwaarden voor een landelijk gunstige staat van instandhouding. Voor de VR-soorten zijn de landelijke en gebiedsdoelen gekwantificeerd voor de populatiegrootte. Voor de doelen t.a.v. kwaliteit ontbreekt het aan referentiewaarden en maatlatten. Ten behoeve van de SDF's zijn wel maatlatten ontwikkeld, maar deze worden niet toegepast voor de beheerplannen.

Meetbaar De Natura 2000-doelen t.a.v. kwantiteit zijn duidelijk uitgedrukt of uit te drukken in meetbare variabelen (verspreiding, populatiegrootte en oppervlakte) en meeteenheden (aantal 10*10 km hokken, aantal ha, aantal individuen). De doelen t.a.v. kwaliteit zijn minder concreet geformuleerd. Er worden diverse variabelen genoemd (vegetatietypen, typische soorten, abiotiek, overige structuur en functiekenmerken) in de profielendocumenten, maar hoe deze variabelen exact te meten en - gezamenlijk - te beoordelen, is onvoldoende duidelijk, vooral wat betreft de kwaliteit van het leefgebied van een soort. In de checklist beheerplannen staat onder de paragraaf instandhoudingsdoelen dat kwaliteitsdoelen concreet en toetsbaar moeten zijn uitgewerkt met de elementen uit het profielendocument.

In de beheerplannen zijn de doelen t.a.v. kwantiteit wat betreft de populatiegrootte van VR-soorten en de oppervlakte het concreetst uitgewerkt. De doelen t.a.v. de van de populatiegrootte van HR-soorten zijn veelal niet gekwantificeerd. De doelen t.a.v. kwaliteit van habitattypen en leefgebieden van soorten zijn veelal niet concreet uitgewerkt en methoden hoe kwaliteit te definiëren en toetsen, verschillen tussen de voortouwnemers. De doelen ten aanzien van de kwaliteit van de habitattypen zijn veelal concreter uitgewerkt dan die voor de kwaliteit van leefgebieden. 


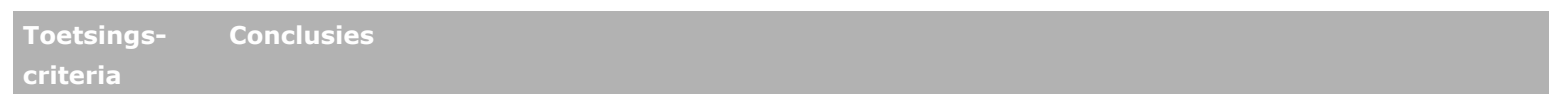

Acceptabel De Natura 2000-doelen zijn acceptabel in de zin dat er uit het principe van strategisch lokaliseren naar de optimale selectie en maximale bijdrage van de Natura 2000-gebieden is gestreefd, uitgaande van de actuele en potentiële situatie (zie onder coherentie intern) en maximaal is aangesloten bij bestaand beleid (zie onder coherentie ander beleid). In de checklist beheerplannen wordt gevraagd onder de sociaaleconomische paragraaf te beschrijven wat de sociaaleconomische consequenties zijn van de maatregelen en wat voor gevolgen er zijn voor activiteiten. Dit wordt door de voortouwnemers/opstellers van de beheerplannen zeer verschillend ingevuld. Er kan hier ook niet uit opgemaakt worden of er ook daadwerkelijk draagvlak is. Dit zou wel kunnen aan de hand van de ingediende zienswijzen (zowel t.a.v. aanwijzingsbesluiten als beheerplannen).

Realistisch De Natura 2000-doelen zijn realistisch in de zin dat een van de hoofdlijnen haalbaar en betaalbaar is. Hoe de haalbaarheid exact is getoetst, is niet duidelijk. Er is een kostenraming gemaakt. In de checklist beheerplannen wordt ook gevraagd naar haalbare en betaalbare doelen. Dit is echter in dit project niet verder onderzocht.

Tijdgebonden Aan de Natura 2000-doelen is geen termijn verbonden. Er mag van de EC echter geen verslechtering plaatsvinden, hetgeen betekent dat er wel een termijn verbonden is aan de maatregelen om een mogelijke verslechtering tegen te gaan. In de checklist beheerplannen wordt onder de paragraaf maatregelen aangegeven dat de Sense of Urgency-maatregelen gedurende de eerste beheerplanperiode genomen moeten worden. Uit de beheerplannen kan echter niet goed worden opgemaakt hoe men hier concreet invulling aan geeft.

Consistent De Natura 2000-doelen zijn consistent in de zin dat er per soort, per habitattype en per aspect - met uitzondering van het toekomstperspectief - van de staat van instandhouding doelen zijn geformuleerd. Bij de uitwerking van de doelen in de beheerplannen ontstaat echter bij vooral de doelen t.a.v. kwaliteit inconsistentie, aangezien men kwaliteit op verschillende manieren beoordeelt (zie ook onder meetbaar).

Alomvattend De Natura 2000-doelen zijn alomvattend in de zin dat er voor alle VR- en HR-soorten (met uitzondering van Annex IV en V) en habitattypen en alle aspecten - met uitzondering van toekomstperspectief doelen (behoud- en herstelopgaven) zijn geformuleerd.

Robuust De Natura 2000-doelen zijn robuust in de zin dat geanticipeerd wordt op natuurlijke dynamiek en klimaatverandering. Hieraan is invulling gegeven met het principe van strategisch lokaliseren en de formulering van kernopgaven per Natura 2000-landschap. Instandhoudingsdoelen zijn geformuleerd voor afzonderlijke soorten en habitattypen, maar ook voor samenhangende landschappen of systemen. De achterliggende analyses zijn echter niet zonder meer beschikbaar, dus dat maakt het lastig om binnen dit project te beoordelen of de doelen inderdaad ook robuust zijn. In de checklist beheerplannen wordt gevraagd onder de paragraaf instandhoudingsdoelen om een landschapsecologische

systeemanalyse uit te voeren. In dit onderzoek is niet nader onderzocht of dit ook daadwerkelijk is gebeurd. Vanuit de PAS is dit verplicht gesteld, dus voor de stikstofgevoelige Natura 2000-gebieden zijn deze analyses wel uitgevoerd.

Flexibel De Natura 2000-doelen zijn flexibel in de zin dat er uit het principe balans tussen richting geven en ruimte laten ruimte wordt geboden aan de voortouwnemers/opstellers van de beheerplannen om de doelen op gebiedsniveau nader uit te werken in omvang, ruimte, tijd en kwaliteit en om ook aanvullende doelen te stellen. Het komt zelden voor de er hogere ambities of aanvullende doelen worden geformuleerd in de beheerplannen. 


\section{Deel II Natura 2000-doelen}

\subsection{Aanleiding en vraagstelling}

De Natura 2000-doelen zijn volgens een bepaalde systematiek geformuleerd en vastgelegd in het Natura 2000-doelendocument en de aanwijzingsbesluiten van de Natura 2000-gebieden. Het Natura 2000-doelendocument stamt uit 2006. In de tussentijd hebben ontwikkelingen plaatsgevonden onder invloed van natuurlijke dynamiek en klimaatveranderingen, maar ook door genomen maatregelen, zoals de herintroductie van soorten en verbetering van de waterkwaliteit, en drukfactoren, zoals verdroging en vermesting. Bovendien is er sprake van voortschrijdend inzicht (bv. de definitie van habitattypen), nieuwe kennis en een verbeterde informatievoorziening (bv. de habitattypenkaarten en verbeterde kennis over vogelslaapplaatsen). Bij de vastlegging van de Natura 2000-doelen in de aanwijzingsbesluiten zijn er al wijzigingen (veelal correcties) doorgevoerd ten opzichte van het Natura 2000-doelendocument.

In de tussentijd is er door het ministerie van Economische Zaken op grond van artikel 17 van de Habitatrichtlijn twee keer gerapporteerd naar de Europese Commissie over de staat van instandhouding van habitattypen (Annex I) en HR- soorten (Annex II, IV en V) over de periodes 20012006 en 2007-2012 (Schmidt en Adams, 2015). De rapportage op grond van artikel 12 van Vogelrichtlijn over de periode 2008-2012 (Van Kleunen et al., 2013) bevat geen beoordeling van de staat van instandhouding van VR-soorten, maar wel de onderliggende gegevens over de verspreiding en de populatiegrootte van VR-soorten. Via de Standard Data Forms (de SDF's) is in de tussentijd ook gerapporteerd over het relatieve belang van de Natura 2000-gebieden voor de staat van instandhouding van habitattypen, HR-soorten en VR-soorten. Hiervoor is de relatieve omvang (oppervlakte habitattype en populatiegrootte soort) en de behoudsstatus (de mate van instandhouding van de structuur en functie van een habitattype en de elementen van het leefgebied van een soort en herstelmogelijkheid) van habitattypen en soorten beoordeeld (Van Kleunen et al., 2014; Ottburg en Janssen, 2014; Janssen et al., 2014).

Een centrale vraag in dit onderdeel (deel 2) van het onderzoek is of de Natura 2000-doelen op landelijk niveau en/of op gebiedsniveau bijgesteld moeten worden gezien de ontwikkelingen die tussen 2006 en 2015 hebben plaatsgevonden. Enerzijds betreft dat een correctie op basis van voortschrijdend inzicht, nieuwe kennis en verbeterde informatie, anderzijds betreft dat een actualisatie op basis van de daadwerkelijke veranderingen die hebben plaatsgevonden.

\subsection{Aanpak}

\subsubsection{Proceslijnen}

De Natura 2000-doelensystematiek is in dit onderzoek geëvalueerd (zie hoofdstuk 3). Dit is echter gelijktijdig uitgevoerd met de evaluatie van de Natura 2000-doelen. Vandaar dat voor de evaluatie van de Natura 2000-doelen een vergelijkbare systematiek is gevolgd als in het Natura 2000doelendocument uit 2006, te weten de twee proceslijnen (zie paragraaf 2.1). Hier is echter op onderdelen van afgeweken. Vergelijkbaar met de proceslijnen in het Natura 2000-doelendocument (zie paragraaf 2.1 en Tabel 1 ) is onderscheid gemaakt in de formulering van landelijk doelen (het landelijk spoor) en de formulering van gebiedsdoelen (het gebiedenspoor), maar de kernopgaven onderdeel van proceslijn 2 uit het Natura 2000-doelendocument - zijn in het huidige onderzoek niet geëvalueerd (zie Figuur 15). Wel in het huidige onderzoek opgenomen, maar geen onderdeel van proceslijn 2 uit het Natura 2000-doelendocument (zie paragraaf 2.1 en Tabel 1), is de selectie van de gebieden en daarmee samenhangend de beoordeling van het relatieve belang ofwel de relatieve bijdrage van het Natura 2000-gebied aan de staat van instandhouding van habitattypen en soorten. 


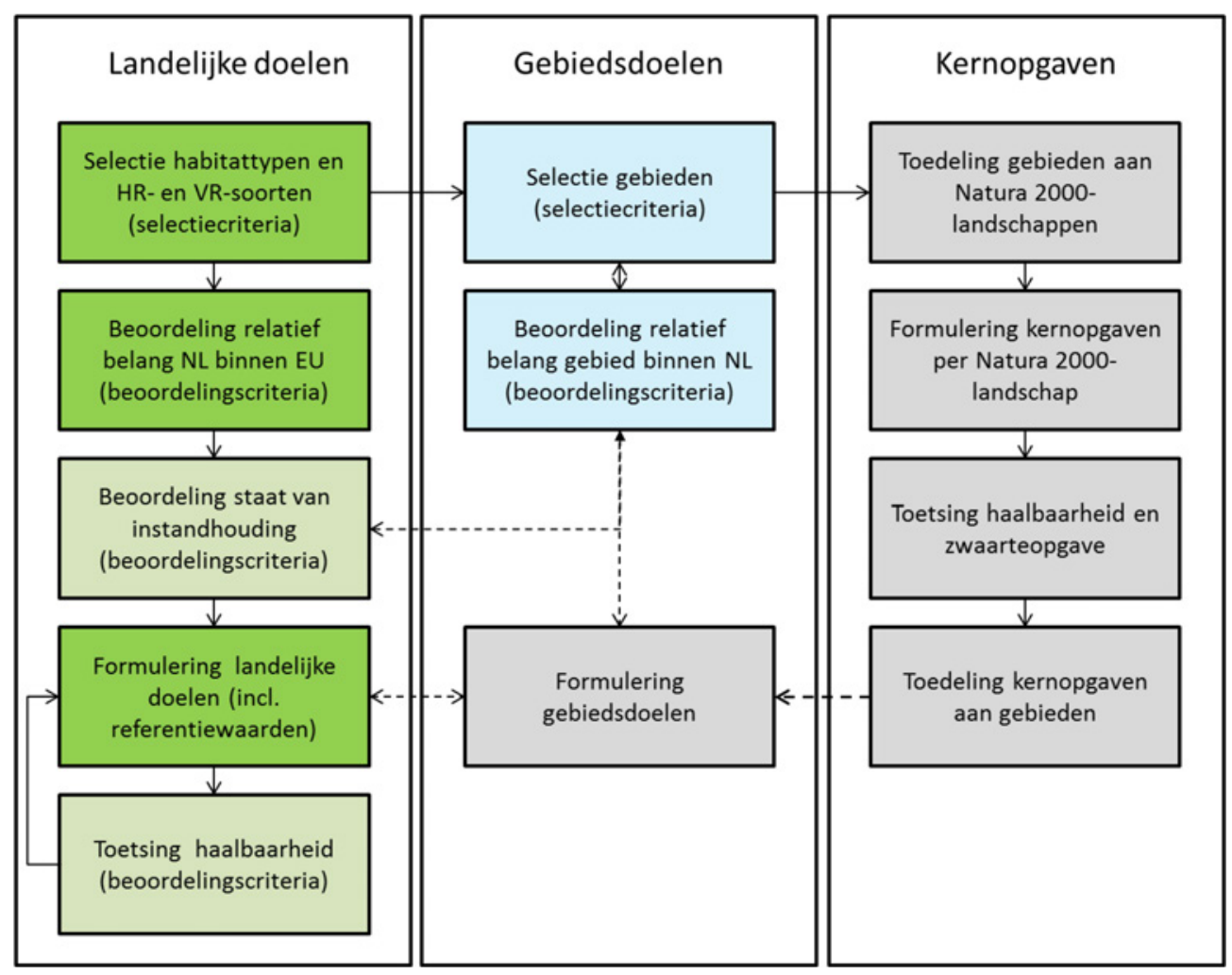

Figuur 15 Processchema: samenhang tussen de verschillende projectonderdelen van het huidige onderzoek in relatie tot de verschillende stappen van de proceslijnen in het Natura 2000doelendocument (zie Tabel 1).

In groen de projectonderdelen die geheel (donkergroen) binnen en deels (lichtgroen) binnen het huidige onderzoek zijn uitgevoerd en die overeenkomen met de stappen van proceslijn 1 van het Natura 2000-doelendocument. In blauw de projectonderdelen die binnen het huidige onderzoek zijn uitgevoerd, maar die geen onderdeel vormen van de stappen in de proceslijnen van het Natura 2000doelendocument. In grijs de stappen die onderdeel uitmaakten van de proceslijnen van het Natura 2000-doelendocument, maar die geen onderdeel uit maken van het huidige onderzoek.

De analyse van de Natura 2000-doelen bestaat dus uit twee sporen, te weten een landelijk spoor en een gebiedenspoor. De nadruk ligt op het gebiedenspoor en specifiek op de selectie van de Natura 2000-gebieden. Voor de VR-soorten wordt ook een concreet advies gegeven over bijstelling van de doelen t.a.v. populatiegrootte (landelijk en per gebied), aangezien hier nieuwe gegevens en kennis over beschikbaar zijn (zie Van Kleunen et al., 2016).

\section{Landelijk spoor}

De onderzoeksvragen zijn:

1. Zijn er 'nieuwe' habitattypen en soorten, ofwel habitattypen en soorten waar nog geen gebieden voor zijn aangewezen en die gezien de hiervoor geldende criteria wel voor in aanmerking komen?

2. Is het belang van Nederland voor de instandhouding van de 'bestaande' habitattypen en soorten, ofwel soorten en habitattypen waar al gebieden voor zijn geselecteerd en/of aangewezen binnen de EU in de tussentijd (2006-2015) veranderd?

3. Is de staat van instandhouding van 'bestaande' habitattypen en soorten in de tussentijd (20062015) veranderd?

4. Is het op grond van het voorgaande $(1 \mathrm{t} / \mathrm{m} \mathrm{3}$ ) wenselijk dat bijstellingen (correctie of actualisatie) van de Natura 2000-doelen op landelijk niveau worden doorgevoerd?

5. Zijn de landelijke doelen ecologisch haalbaar?

Onderzoeksvraag 4 wordt maar beperkt beantwoord in dit onderzoek, aangezien de focus ligt op de selectie en de aanwijzing van Natura 2000-gebieden voor 'nieuwe' en 'bestaande' soorten en habitattypen (zie volgende paragraaf). Over de Natura 2000-doelen t.a.v. de populatiegrootte van 
VR-soorten wordt wel een advies gegeven over bijstellingen, gezien het feit dat hier nu betere en actuele gegevens over beschikbaar zijn en de inzichten tussentijds ook zijn veranderd (zie voor details Van Kleunen et al., 2016). Onderzoeksvraag 5 is in dit onderzoek ook beperkt tot de Natura 2000doelen t.a.v. Vogelrichtlijnsoorten, aangezien dit voor de habitattypen en Habitatrichtlijnsoorten al eerder is geëvalueerd (Bijlsma et al., 2014b).

\section{Gebiedenspoor}

De onderzoeksvragen zijn:

1. Welke Natura 2000-gebieden (bestaande of nieuwe) zijn van belang voor de instandhouding van de 'nieuwe' habitattypen en soorten en zouden geselecteerd en aangewezen moeten worden voor de betreffende habitattypen en soorten?

2. Is het relatieve belang van de Natura 2000-gebieden voor de instandhouding van 'bestaande' habitattypen en soorten tussentijds (2006-2015) veranderd? Zo ja, is het wenselijk om de selectie en de aanwijzing van de gebieden hierop aan te passen?

Het gebiedenspoor is vooral gericht op de selectie en vervolgens aanwijzing van de Natura 2000gebieden en niet op de formulering van behoud- en herstelopgaven voor habitattypen en soorten in de betreffende gebieden. Voor de doelen t.a.v. de populatiegrootte van de Vogelrichtlijnsoorten wordt binnen dit onderzoek wel een advies gegeven over wenselijke bijstellingen, gezien het feit dat hier nu betere en actuele gegevens voor beschikbaar zijn en de inzichten (o.a. qua methodiek) tussentijds zijn veranderd, zie Van Kleunen et al., (2016). Dit is samengevat in paragraaf 4.3.2.2.

\subsubsection{Toegepaste methoden}

Bij de uitvoering van de verschillende projectonderdelen is zo veel mogelijk aangesloten bij de in het Natura 2000-doelendocument gevolgde methoden (zie Tabel 4).

Tabel $5 \quad$ Korte toelichting ofwel verwijzing naar de binnen het huidige onderzoek toegepaste methoden.

\begin{tabular}{|c|c|}
\hline Projectonderdeel & Korte toelichting op de gevolgde methodiek \\
\hline $\begin{array}{l}\text { Definitie (selectie) van } \\
\text { habitattypen en soorten }\end{array}$ & $\begin{array}{l}\text { Conform de selectiecriteria zoals ook toegepast in het Natura 2000-doelendocument (zie } \\
\text { paragraaf } 2.1 .2 .1 \text { ). }\end{array}$ \\
\hline $\begin{array}{l}\text { Beoordeling staat van } \\
\text { instandhouding }\end{array}$ & $\begin{array}{l}\text { Conform de voorschriften van de Europese Commissie. Zie ook Bijlage } 3 \text { van dit rapport. } \\
\text { Voor vogelsoorten is de 'indicatieve' staat van instandhouding beoordeeld voor de periode } \\
2008-2012 \text { (Foppen et al., in 2016). }\end{array}$ \\
\hline Formulering landelijke doelen & $\begin{array}{l}\text { Voor de VR-soorten onder meer gebaseerd op de actueelste gegevens over de status en } \\
\text { trend in populatiegrootte (Kleunen et al., 2016). }\end{array}$ \\
\hline $\begin{array}{l}\text { Toetsing ecologische } \\
\text { haalbaarheid }\end{array}$ & $\begin{array}{l}\text { Voor de VR-soorten conform een binnen het huidige onderzoek ontwikkelde en } \\
\text { toegepaste beoordelingsmethodiek (Foppen et al., 2016), die deels gebaseerd is op de } \\
\text { beoordelingsmethodiek ontwikkeld en toegepast voor de habitattypen en HR-soorten van } \\
\text { Bijlsma et al. (2014b). }\end{array}$ \\
\hline Selectie gebieden & $\begin{array}{l}\text { Conform de selectiecriteria zoals toegelicht in de Nota van antwoord Vogelrichtlijn en in } \\
\text { het Verantwoordingsdocument. Zie ook Bijlage } 1 \text { van dit rapport. }\end{array}$ \\
\hline $\begin{array}{l}\text { Beoordeling relatief belang } \\
\text { gebieden }\end{array}$ & Conform de voorschriften van de Europese Commissie. Zie ook Bijlage 2 van dit rapport. \\
\hline $\begin{array}{l}\text { Bijstellingen landelijke en } \\
\text { gebiedsdoelen populatiegrootte } \\
\text { VR-soorten }\end{array}$ & $\begin{array}{l}\text { Op basis van geactualiseerde informatie over status en trend in populatiegrootte } \\
\text { (landelijk en per gebied) van VR-soorten (zie voor details Kleunen van et al., 2016) }\end{array}$ \\
\hline
\end{tabular}

\subsubsection{Geraadpleegde bronnen}

Voor de evaluatie van de Natura 2000-doelen landelijk en per gebied zijn verschillende bronnen geraadpleegd (zie Tabel 6). 
Tabel 6 Informatiebronnen die geraadpleegd zijn voor de evaluatie van de Natura 2000-doelen.

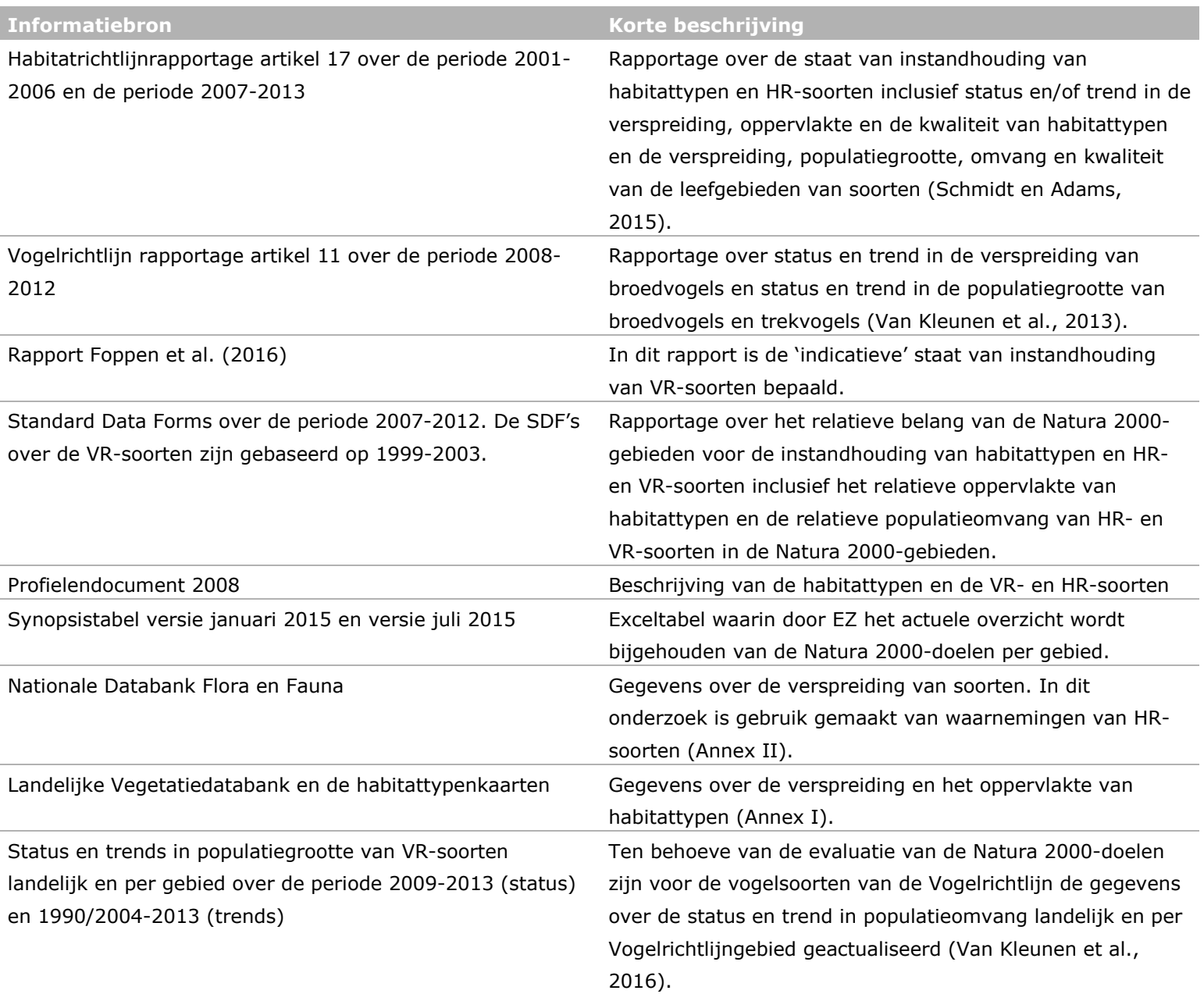

\subsection{Resultaten}

In dit hoofdstuk worden de belangrijkste resultaten van de evaluatie van de Natura 2000-doelen samengevat. Voor een uitgebreide toelichting hierop wordt verwezen naar de technische achtergrondrapporten over respectievelijk de evaluatie van de Natura 2000-doelen (Van Kleunen et al., 2016) en de evaluatie van de ecologische haalbaarheid van de Natura 2000 instandhoudingsdoelen voor vogels (Foppen et al., 2016).

\subsubsection{Landelijke doelen}

\subsubsection{Selectie van 'nieuwe' habitattypen en soorten}

\section{Habitattypen}

Er is één nieuw habitattype bijgekomen sinds 2006, te weten Riffen van open zee (H1170). Het voorkomen van dit habitattype, dat voorheen niet voor Nederland op de Atlantische referentielijst stond, is nu onderkend. Voor dit type wordt het gebied Klaverbank aangewezen.

Bij vergelijking van de Nederlandse interpretatie met die in omringende landen komt een viertal habitattypen naar voren dat eventueel ook in Nederland onderscheiden kan worden, deels op basis van nieuwe vegetatiekundige inzichten, deels om meer consistentie te krijgen met het buitenland (zie Tabel 6). In de tekstboxen worden dit nader toegelicht. 
Habitattype H1210 is in de Europese handleiding gedefinieerd als een type van rolkeistranden (shingles), maar wordt in de praktijk door vrijwel alle landen ook toegepast op zandstranden. Nederland vormt hierbij een uitzondering, en het verspreidingskaartje van dit habitattype laat dan ook een gat zien langs de Nederlandse kust. Op zandstrand is het type in ons land wijd verspreid, met name op de Waddeneilanden. Voor de bescherming van dit habitattype zijn reeds alle belangrijke gebieden aangewezen.

Habitattype $\mathrm{H} 1220$ is eveneens een type van rolkeistranden (shingles), maar komt [i.t.t. de vorige] niet voor op zandstranden. In Nederland worden begroeiingen van dit habitat (beschreven onder de associatie Crambo-Atriplicetum glabriusculae (De Jager \& Weeda, 2000)) echter zeer zeldzaam aangetroffen op schelpenstranden, een substraat dat overeenkomt met dat van rolkeistranden. Er zijn twee à drie locaties in Nederland waar sprake is van dit habitattype; deze liggen voor zover bekend alle binnen de grenzen van Natura 2000-gebieden. Het nieuw onderscheiden vegetatietype wordt in een revisie van de Vegetatie van Nederland (Schaminée et al., in prep.) overigens beschreven onder de naam Crithmo-Crambetum maritimae.

Midden-Europese Beukenbossen

Onder de habitattypen H9130 en H9150 wordt in België een deel van de bossen opgevat dat in Nederland tot habitattype H9160A wordt gerekend. Het habitattype H9130 betreft in deze opvatting Carpinionbossen op neutrale bodems, het habitattype H9150 op kalkbodems. De Nederlandse interpretatie om alle Carpinion-bossen tot habitattype $\mathrm{H} 9160$ te rekenen, kan als onjuist worden opgevat door een zinsnede in de Europese handleiding die rept van "Not to be confused with forests of Quercus robur arising from the management of beech-oak forests as coppice or coppice-with-standards on well drained soils". Een deel van de Nederlandse H9160-bossen voldoet namelijk aan dit managementkenmerk. Aan de andere kant is het niet zeker dat deze beheerde bossen zich op den duur zullen ontwikkelen tot beukenbossen (typen H9130 en H9150). Het onderscheid maken tussen de drie verwante habitattypen wordt vereenvoudigd door het splitsen van het kwalificerende vegetatietype Stellario-Carpinetum in drie associaties, die elk voor een ander habitattype kwalificeren: Carici-Carpinetum (type H9150), Primulo-Carpinetum (type H9130) en Stellario-Carpinetum (type H9160). Deze indeling is eerder ook in Den Ouden et al. (2014) beschreven en wordt overgenomen bij de revisie van de Vegetatie van Nederland (Schaminée et al. in prep.).

Voor geen van deze habitattypen hoeven nieuwe gebieden te worden aangewezen. De typen H9130 en H9150 zijn nu reeds opgenomen binnen het Natura 2000-netwerk, alleen onder de code H9160. De belangrijkste locaties van $\mathrm{H} 1210$ en H1220 zijn onderdeel van Natura 2000-gebieden in het kustgebied. Mogelijk moet hierbij wel soms de begrenzing net iets aangepast worden om deze locaties binnen het Natura 2000-netwerk te krijgen, maar dit is niet in detail uitgezocht.

Van een aantal habitattypen zijn in de tussentijd de definities veranderd, hetgeen tot consequenties kan leiden voor de selectie en de beoordeling van het relatieve belang van de hiervoor aangewezen gebieden (zie Tabel 7). Voor de meeste habitattypen heeft de gewijzigde definitie geen consequenties voor de geselecteerde gebieden van het Natura 2000-netwerk. Voor H6230 kan dat op dit moment nog niet ingeschat worden, omdat de herzieningen nog niet voorhanden zijn. Voor H7140 betekent de verbreding dat bij een nieuwe selectie het gebied 'De Mieden' in Friesland in aanmerking komt voor selectie onder Natura 2000 vanwege de uitzonderlijke kwaliteit van beekdal-trilveen. Voor het type 9160, dat relatief met een laag percentage wordt afgedekt door Natura 2000-gebieden, komen twee nieuwe gebieden in beeld: het IJzeren Bos in Limburg, en Landgoed De Byvanck in Gelderland. Ook voor de bostypen 9120 en 9190 kan de herziening een nieuwe lijst van beste gebieden opleveren, waarbij met name de Utrechtse Heuvelrug in beeld komt. 
Tabel 7 Belangrijkste wijzigingen in de definities van habitattypen tussen 2003 en 2015 en een inschatting van de consequenties voor een eventuele nieuwe selectie van gebieden en het belang van gebieden.

\begin{tabular}{|c|c|c|c|}
\hline Code & Naam habitattype & Verandering definitie & Inschatting consequenties \\
\hline $\mathrm{H} 2310$ & $\begin{array}{l}\text { Stuifzandheiden met } \\
\text { struikhei }\end{array}$ & $\begin{array}{l}\text { Definitie veranderd; mede } \\
\text { gebaseerd op bodemtype }\end{array}$ & Waarschijnlijk geen \\
\hline $\mathrm{H} 2330$ & Zandverstuivingen & $\begin{array}{l}\text { Definitie veranderd; breder } \\
\text { getrokken naar graslanden, minder } \\
\text { open zand }\end{array}$ & Waarschijnlijk geen \\
\hline H3260 & $\begin{array}{l}\text { Beken en rivieren met } \\
\text { waterplanten }\end{array}$ & Definitie verbreed & Mogelijk; relatief slechte gegevens voorhanden \\
\hline H6120 & Stroomdalgraslanden & Definitie verbreed & Waarschijnlijk geen \\
\hline H6230 & Heischrale graslanden & $\begin{array}{l}\text { Definitie zou mogelijk herzien } \\
\text { moeten worden door veranderingen } \\
\text { opvattingen in vegetatieoverzicht } \\
\text { (in } 2015 \text { uitgewerkt) }\end{array}$ & $\begin{array}{l}\text { Waarschijnlijk wel; op basis van beste kwaliteit } \\
\text { komen mogelijk andere gebieden in de Top5, } \\
\text { maar wel allemaal al N2000-gebieden }\end{array}$ \\
\hline H6410 & Blauwgraslanden & $\begin{array}{l}\text { Definitie verbreed naar deel } \\
\text { Veldrusschraalland }\end{array}$ & Waarschijnlijk geen \\
\hline H6430 & Ruigten en zomen & $\begin{array}{l}\text { Definitie veranderd; sterker gericht } \\
\text { op bijzondere soorten }\end{array}$ & Waarschijnlijk geen \\
\hline H6510 & $\begin{array}{l}\text { Glanshaver- en } \\
\text { vossenstaarthooilanden }\end{array}$ & $\begin{array}{l}\text { Definitie verbreed (trosdravik- } \\
\text { rompgemeenschap) }\end{array}$ & Waarschijnlijk geen \\
\hline H7110 & Actieve hoogvenen & Definitie strikter & Waarschijnlijk geen \\
\hline $\mathrm{H} 7140$ & Overgangs- en trilvenen & $\begin{array}{l}\text { Definitie verbreed naar beekdal- } \\
\text { overgangsveen }\end{array}$ & Waarschijnlijk geen \\
\hline H9160 & Eiken-haagbeukenbossen & $\begin{array}{l}\text { Veel nieuwe gegevens beschikbaar } \\
\text { gekomen }\end{array}$ & $\begin{array}{l}\text { Waarschijnlijk wel. Subtype A wordt relatief } \\
\text { slecht afgedekt door Natura 2000; er komen } \\
\text { nieuwe gebieden in aanmerking voor selectie } \\
\text { onder Natura } 2000 \text { (IJzeren Bos) }\end{array}$ \\
\hline H9190 & Oude eikenbossen & Definitie ingeperkt tot oude bossen & $\begin{array}{l}\text { Waarschijnlijk wel. Er komen nieuwe gebieden } \\
\text { in aanmerking voor selectie onder Natura } 2000 \\
\text { (Utrechtse Heuvelrug) }\end{array}$ \\
\hline H91D0 & Hoogveenbossen & $\begin{array}{l}\text { Definitie veranderd doordat beste } \\
\text { voorbeelden nu tot } 7120 \text { worden } \\
\text { gerekend }\end{array}$ & $\begin{array}{l}\text { Onduidelijk. Nog steeds relatief slechte } \\
\text { gegevens voorhanden; bijdrage gebieden moet } \\
\text { opnieuw worden bekeken }\end{array}$ \\
\hline
\end{tabular}

\section{HR-soorten}

Er zijn vijf HR-soorten die sinds een aantal jaren weer in Nederland voorkomen: de otter (H1355), brede geelgerande waterroofkever (H1081), vermiljoenkever (H1086), mercuurwaterjuffer (H1044) en Bechsteins vleermuis (H1323). De otter en de brede geelgerande waterroofkever zijn naar aanleiding van de artikel 17-rapportage van 2013 voor Nederland op de Atlantische referentielijst geplaatst, want zij planten zich al meer dan tien jaar aaneengesloten voort in Nederland. Voor de vermiljoenkever, mercuurwaterjuffer en Bechsteins vleermuis is het nog te vroeg gebieden aan te wijzen. De mercuurwaterjuffer is pas in juni 2011 herontdekt bij Swalmen in Limburg (Vlinderstichting, 2012). In Duitsland en België komen populaties voor op minder dan $100 \mathrm{~km}$ van de Nederlandse grens (Vlinderstichting, 2012). Het betreft een Zuid-Europese soort. De Bechsteins vleermuis is in ons land zeer zeldzaam. In 2009 is een voortplantingslocatie van de Bechsteins vleermuis herontdekt in ZuidLimburg. Winterslapende dieren werden al langer aangetroffen op enkele plaatsen in Zuid-Limburg 
(o.a. Cannerberg, St. Pietersberg Noord/ENCI-groeve, Savelsbos), Overijssel en recentelijk ook in Gelderland (bij Nieuw-Milligen). Het Europees belang voor deze drie soorten is onbekend.

\section{VR-soorten}

Van de lijst van Nederlandse vogelsoorten zijn er 32 die wel op Annex I van de Vogelrichtlijn staan, maar waarvoor geen gebieden zijn aangewezen. Van deze 32 soorten zijn er 15 waarvoor mogelijk Vogelrichtlijnbieden in aanmerking komen op basis van de huidige criteria:

- of ze concentraties vormen;

- of er sprake is van vaste verblijfplaatsen;

- of voldoende kennis is over de aantallen op die verblijfplaatsen;

- en of de exemplaren in Nederland van wilde herkomst zijn.

De soorten die hieraan voldoen, staan in Tabel 8 (zie ook van Kleunen et al 2016). De overige 17 soorten voldoen niet aan deze criteria (zie van Kleunen et al., 2016).

Tabel 8 Broedvogels en niet-broedvogels van Annex I van de Vogelrichtlijn die in aanmerking komen voor de eventuele selectie en aanwijzing van Vogelrichtlijngebieden in Nederland.

\begin{tabular}{ll} 
Soort & Omschrijving populatie Nederland \\
\hline Brandgans & Broedvogel \\
\hline Dwergmeeuw & Broedvogel \\
\hline Dwergstern & Doortrekker \\
\hline Grote Stern & Doortrekker \\
\hline IJsduiker & Wintergast \\
\hline Kleinst Waterhoen & Broedvogel \\
\hline Kraanvogel & Broedvogel \\
\hline Kwak & Broedvogel \\
\hline Lachstern & Doortrekker \\
\hline Middelste Bonte Specht & Broedvogel \\
\hline Oehoe & Broedvogel \\
\hline Ooievaar & Broedvogel \\
\hline Slechtvalk & Broedvogel \\
\hline Visdief & Doortrekker \\
\hline Zeearend & Broedvogel \\
\hline
\end{tabular}

Op de lijst van Nederlandse vogelsoorten staan 46 watervogelpopulaties waarvoor geen Vogelrichtlijngebieden zijn aangewezen. Van deze 46 zijn er 12 waarvoor mogelijk Vogelrichtlijngebieden in aanmerking komen op basis van de criteria:

- of ze trekvogel zijn;

- of ze concentraties vormen;

- of er sprake is van vaste verblijfplaatsen;

- of er voldoende kennis is over de aantallen op die verblijfplaatsen;

- en of het de exemplaren in Nederland van wilde herkomst zijn.

De soorten die hieraan voldoen, staan in Tabel 9. De overige 33 watervogelpopulaties voldeden niet aan deze criteria (Kleunen van et al. 2016). 
Tabel 9 Trekkende watervogels niet op Bijlage 1 van de Vogelrichtlijn die mogelijk in aanmerking komen voor de selectie en aanwijzing van Vogelrichtlijngebieden in Nederland.

\begin{tabular}{ll} 
Soortnaam & Omschrijving populatie Nederland \\
Grote Mantelmeeuw & doortrekker/wintergast \\
\hline Grote Zee-eend & doortrekker/wintergast \\
\hline IJseend & Wintergast \\
\hline Kokmeeuw & doortrekker/wintergast \\
\hline Paarse Strandloper & doortrekker/wintergast \\
\hline Regenwulp & Doortrekker \\
\hline Roodhalsgans & Wintergast \\
\hline Stormmeeuw & doortrekker/wintergast \\
\hline Witvleugelstern & Doortrekker \\
\hline Zilvermeeuw (ssp. argentatus) & Wintergast \\
\hline Zomertaling & Doortrekker \\
\hline Blauwe Reiger & broedvogel - gedeeltelijk wegtrekkend \\
\hline
\end{tabular}

Voor de overige trekvogels geldt dat er geen aparte Vogelrichtlijngebieden hoeven te worden aangewezen (volgens de Nederlandse aanwijssystematiek), maar dat ze wel kunnen worden toegevoegd aan Vogelrichtlijngebieden die reeds kwalificeren voor de soorten van Annex I of watervogels waarvoor Nederland van internationaal belang is (ministerie van Landbouw, Natuur en Voedselkwaliteit, 2000). In de criteria is vastgesteld dat trekvogels van de Rode Lijst hiervoor in aanmerking kunnen komen. Voor de beoordeling is hiervoor gebruikgemaakt van de door het CBS vastgestelde virtuele Rode Lijst voor broedvogels van 2015 (https://www.cbs.nl/nl-

$\mathrm{nl} /$ artikelen/achtergrond/2013/43/licht-herstel-biodiversiteit/indicator-biodiversiteit) en voor doortrekkers en overwinteraars van de in 2015 voor Vogelbescherming Nederland opgesteld Rode Lijst voor deze groep van populaties (Van Kleunen et al. 2015).

Van de 18 aan de criteria getoetste broedvogelpopulaties komt er één in aanmerking om als aanwijssoort te worden toegevoegd aan bestaande Vogelrichtlijngebieden. Van de elf beoordeelde doortrek-/winterpopulaties komen zes mogelijk in aanmerking hiervoor (zie Tabel 10), zie ook Van Kleunen et al. (2016).

Tabel 10 Overige trekvogels niet op Bijlage 1 van de Vogelrichtlijn die mogelijk in aanmerking komen om mede te selecteren in al aangewezen gebieden.

\begin{tabular}{ll} 
Soortnaam & Type populatie \\
Buidelmees & Broedvogel \\
\hline Blauwe Kiekendief & Doortrekker/wintergast \\
\hline Frater & Wintergast \\
\hline Ruigpootbuizerd & Wintergast \\
\hline Sneeuwgors & Doortrekker/wintergast \\
\hline Strandleeuwerik & Doortrekker/wintergast \\
\hline Velduil & Doortrekker/wintergast \\
\hline
\end{tabular}

\subsubsection{Actualisatie van het relatieve belang van Nederland binnen EU, de Atlantische regio en/of de Oost-Atlantische vliegroute (Fly way) voor 'bestaande' habitattypen en soorten}

Habitattypen

Er zijn 40 habitat(sub)typen waarvan het Europees belang is aangepast ten opzichte van het Europees belang, zoals vermeld in het Natura 2000-doelendocument (ministerie van Landbouw, Natuur en Voedselkwaliteit, 2006). Voor 33 habitat(sub)typen is het belang lager vastgesteld, voor 7 habitat(sub)typen hoger (zie Tabel 11). De overige 36 habitat(sub)typen zijn gelijk gebleven. 
Tabel 11 Actualisatie relatieve belang van Nederland voor de Europese Unie (EU) en de Atlantische regio (ATL) voor de habitattypen, weergegeven onder de naam Huidig relatief belang EU en ATL. Alleen de (sub)typen waarvan het Europees belang is aangepast ten opzichte van het Natura 2000doelendocument (Ministerie van LNV, 2006) zijn weergegeven.

\begin{tabular}{|c|c|c|c|c|c|}
\hline Code & Naam (met subtypen) & $\begin{array}{l}\text { Correctie } \\
\text { t.o.v. vorig } \\
\text { relatief } \\
\text { belang EU }{ }^{1}\end{array}$ & $\begin{array}{l}\text { Huidig } \\
\text { relatief } \\
\text { belang } \\
\text { EU }{ }^{2}\end{array}$ & $\begin{array}{l}\text { Vorig } \\
\text { relatief } \\
\text { belang } \\
\text { EU }{ }^{2}\end{array}$ & $\begin{array}{l}\text { Huidig } \\
\text { relatief } \\
\text { belang } \\
\text { ATL }^{2}\end{array}$ \\
\hline $1310 \mathrm{~A}$ & Zilte pionierbegroeiingen(zeekraal) & - & $* *$ & $* * *$ & $* * *$ \\
\hline $1330 \mathrm{~A}$ & Schorren en zilte graslanden (buitendijks) & - & $* *$ & $* * *$ & $* * *$ \\
\hline 2150 & Duinheiden met struikhei & + & $* * *$ & $*$ & $* * *$ \\
\hline 2170 & Kruipwilgstruwelen & + & $* * *$ & $* *$ & $* * *$ \\
\hline $2180 \mathrm{C}$ & Duinbossen (binnenduinrand) & + & $* * *$ & $* *$ & $* * *$ \\
\hline $2190 \mathrm{~A}$ & Vochtige duinvalleien (open water) & - & $* *$ & $* * *$ & $* * *$ \\
\hline $2190 \mathrm{C}$ & Vochtige duinvalleien (ontkalkt) & - & $* *$ & $* * *$ & $* * *$ \\
\hline 3110 & Zeer zwakgebufferde vennen & - & $*$ & $* *$ & $*$ \\
\hline 3130 & Zwakgebufferde vennen & - & $* *$ & $* * *$ & $* *$ \\
\hline 3140 & Kranswierwateren & - & $* *$ & $* * *$ & $* * *$ \\
\hline 3150 & Meren met krabbenscheer en fonteinkruiden & - & $* *$ & $* * *$ & $* *$ \\
\hline 3160 & Zure vennen & - & $*$ & $* *$ & $* * *$ \\
\hline $3260 A$ & Beken en rivieren met waterplanten (waterranonkels) & - & $*$ & $* *$ & $*$ \\
\hline 3270 & Slikkige rivieroevers & - & $*$ & $* *$ & $*$ \\
\hline $4010 \mathrm{~A}$ & Vochtige heiden (hogere zandgronden) & - & $* *$ & $* * *$ & $* *$ \\
\hline 5130 & Jeneverbesstruwelen & - & $*$ & $* *$ & $*$ \\
\hline $6430 \mathrm{~A}$ & Ruigten en zomen (moerasspirea) & + & $* *$ & $*$ & $* *$ \\
\hline $6510 \mathrm{~A}$ & $\begin{array}{l}\text { Glanshaver- en vossenstaarthooilanden } \\
\text { (glanshaver) }\end{array}$ & - & $*$ & $* * *$ & $*$ \\
\hline $6510 B$ & $\begin{array}{l}\text { Glanshaver- en vossenstaarthooilanden } \\
\text { (grote vossenstaart) }\end{array}$ & - & $* *$ & $* * *$ & $* *$ \\
\hline $7110 \mathrm{~A}$ & Actieve hoogvenen (hoogveenlandschap) & - & $*$ & $* * *$ & $* *$ \\
\hline $7110 \mathrm{~B}$ & Actieve hoogvenen (heideveentjes) & - & $* *$ & $* * *$ & $* *$ \\
\hline 7120 & Herstellende hoogvenen & - & $* *$ & $* * *$ & $* *$ \\
\hline $7140 \mathrm{~A}$ & Overgangs- en trilvenen (trilvenen) & - & $* *$ & $* * *$ & $* *$ \\
\hline $7140 \mathrm{~B}$ & Overgangs- en trilvenen (veenmosrietlanden) & - & $* *$ & $* * *$ & $* *$ \\
\hline 7230 & Kalkmoerassen & - & $*$ & $* *$ & $*$ \\
\hline $9160 \mathrm{~A}$ & Eiken-haagbeukenbossen (hogere zandgronden) & - & $*$ & $* *$ & $* *$ \\
\hline $9160 \mathrm{~B}$ & Eiken-haagbeukenbossen (heuvelland) & - & $*$ & $* *$ & $* *$ \\
\hline 9190 & Oude eikenbossen & - & $* *$ & $* * *$ & $* *$ \\
\hline $91 \mathrm{EOA}$ & Vochtige alluviale bossen (zachthoutooibossen) & - & $* *$ & $* * *$ & $* *$ \\
\hline $91 \mathrm{EOB}$ & Vochtige alluviale bossen (essen-iepenbossen) & - & $* *$ & $* * *$ & $* *$ \\
\hline $91 \mathrm{E} 0 \mathrm{C}$ & Vochtige alluviale bossen (beekbegeleidende bossen) & - & $*$ & $* *$ & $* *$ \\
\hline
\end{tabular}


De wijzigingen zijn het gevolg van een andere werkwijze, waarbij de gegevens nu veel beter onderbouwd zijn met data uit de HD Artikel 17-rapportage. In het doelendocument waren nog geen harde gegevens voorhanden en was het Europees belang uitsluitend gebaseerd op een expert-oordeel. Aangezien de Artikel 17-rapportages op verschillende schaalniveaus worden aangeleverd, is het relatieve belang voor de hele EU27 uitgevoerd (het $28^{\mathrm{e}}$ land, Kroatië, had nog niet gerapporteerd) en op de schaal van de Atlantische Regio, waar Nederland geheel binnen ligt. Op dit laatste schaalniveau wordt binnen Europa de staat van instandhouding geëvalueerd.

\section{HR-soorten}

Het Europees belang zoals aangegeven in het Natura 2000-doelendocument (2006) is van 21 soorten aangepast. Voor 13 soorten is het belang naar beneden bijgesteld, voor 8 soorten naar boven (Tabel 12). Voor de otter en de brede geelgerande waterroofkever is voor het eerst het relatieve belang bepaald. Voor de overige 14 soorten is het relatieve belang gelijk gebleven.

Tabel 12 Actualisatie relatieve belang van NL binnen de EU en de Atlantisch regio voor de Habitatrichtlijnsoorten Annex II (inclusief de brede geelgerande waterroofkever en de otter).

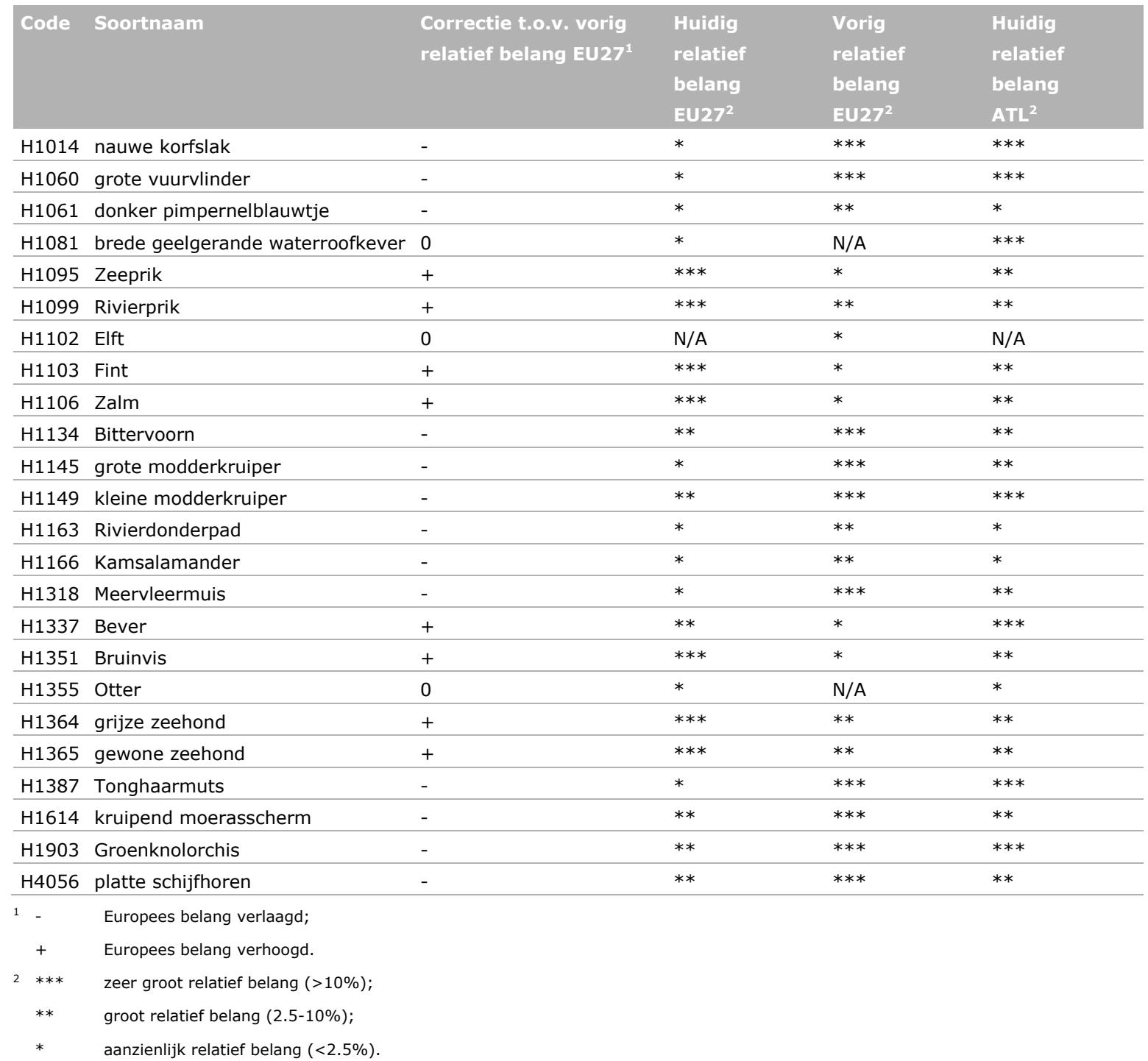

\section{$V R$-soorten}

Voor de broedvogels is in dertien gevallen het relatieve belang van de Nederlandse broedpopulatie in de EU kleiner geworden en in één geval groter. Voor de niet-broedvogels, die bijna allemaal watervogels zijn, wordt het relatieve belang ten opzichte van de flyway-populatie (ook wel biogeografische populatie genoemd) gewogen conform de werkwijze in het Natura 2000- 
doelendocument. In tien gevallen is het relatieve belang van de Nederlandse populatie ten opzichte van de Flyway-populatie kleiner geworden en in drie gevallen groter (zie Tabel 13). Dit is voor broedvogels en niet-broedvogels vooral het gevolg van de beschikbaarheid van andere, veelal betere populatieschattingen voor de EU en/of Flyway-populaties, in plaats van werkelijk grote verschuivingen in het belang van Nederland.

Tabel 13 Actualisatie relatieve belang van NL binnen EU voor de VR-soorten op basis van gegevens uit 2009-2013. Alleen de soorten waarvoor het relatieve belang is veranderd, zijn weergegeven.

\begin{tabular}{|c|c|c|c|c|}
\hline Code & Soortnaam & Type populatie & Vorig relatief belang ${ }^{1}$ & Relatief belang 2009-2013 \\
\hline A008 & Geoorde Fuut & Broedvogel & $* * *$ & $* *$ \\
\hline A017 & Aalscholver & Broedvogel & $* * *$ & $* *$ \\
\hline A029 & Purperreiger & Broedvogel & $* * *$ & $* *$ \\
\hline A072 & Wespendief & Broedvogel & $* *$ & $*$ \\
\hline A132 & Kluut & Broedvogel & $* * *$ & $* *$ \\
\hline A137 & Bontbekplevier & Broedvogel & $* *$ & $*$ \\
\hline A151 & Kemphaan & Broedvogel & $*$ & $?$ \\
\hline A176 & Zwartkopmeeuw & Broedvogel & $* * *$ & $* *$ \\
\hline A224 & Nachtzwaluw & broedvogel & $*$ & $* *$ \\
\hline A229 & IJsvogel & broedvogel & $* *$ & $*$ \\
\hline A236 & Zwarte Specht & broedvogel & $* *$ & $*$ \\
\hline A001 & Roodkeelduiker & niet-broedvogel & $* * *$ & $* *$ \\
\hline A002 & Parelduiker & niet-broedvogel & $* *$ & $*$ \\
\hline A017 & Aalscholver & niet-broedvogel & $* * *$ & $* *$ \\
\hline A027 & Grote Zilverreiger & niet-broedvogel & $*$ & $* *$ \\
\hline A039a & Taigarietgans & niet-broedvogel & $* *$ & $*$ \\
\hline A142 & Kievit & niet-broedvogel & $* * *$ & $* *$ \\
\hline A151 & Kemphaan & niet-broedvogel & $* *$ & $*$ \\
\hline A162 & Tureluur & niet-broedvogel & $* *$ & $* * *$ \\
\hline A177 & Dwergmeeuw & niet-broedvogel & $* *$ & $* * *$ \\
\hline A190 & Reuzenstern & niet-broedvogel & $*$ & $* *$ \\
\hline A197 & Zwarte Stern & niet-broedvogel & $* * *$ & $* *$ \\
\hline $1 * * *$ & zeer groot relatief belang; & & & \\
\hline$* *$ & groot relatief belang; & & & \\
\hline$*$ & aanzienlijk relatief belang. & & & \\
\hline
\end{tabular}

\subsubsection{Actualisatie van de staat van instandhouding van 'bestaande' habitattypen en soorten}

Habitattypen

De staat van instandhouding is voor 42 habitattypen gelijk gebleven, voor 1 habitattype is in 2013 een betere staat van instandhouding gerapporteerd en voor 8 habitattypen een slechtere (zie Tabel 14). Echter, geen van deze veranderingen betreft een daadwerkelijke verbetering of verslechtering, maar is te verklaren door verschillen in de toegepaste methoden en is dus te beschouwen als een correctie. 
Het habitattype H1170 Riffen is later toegevoegd en daarvoor kan dus geen vergelijking worden gemaakt.

Tabel 14 De staat van instandhouding van habitattypen voor de periode 2001-2006 en de periode 2007-2012.

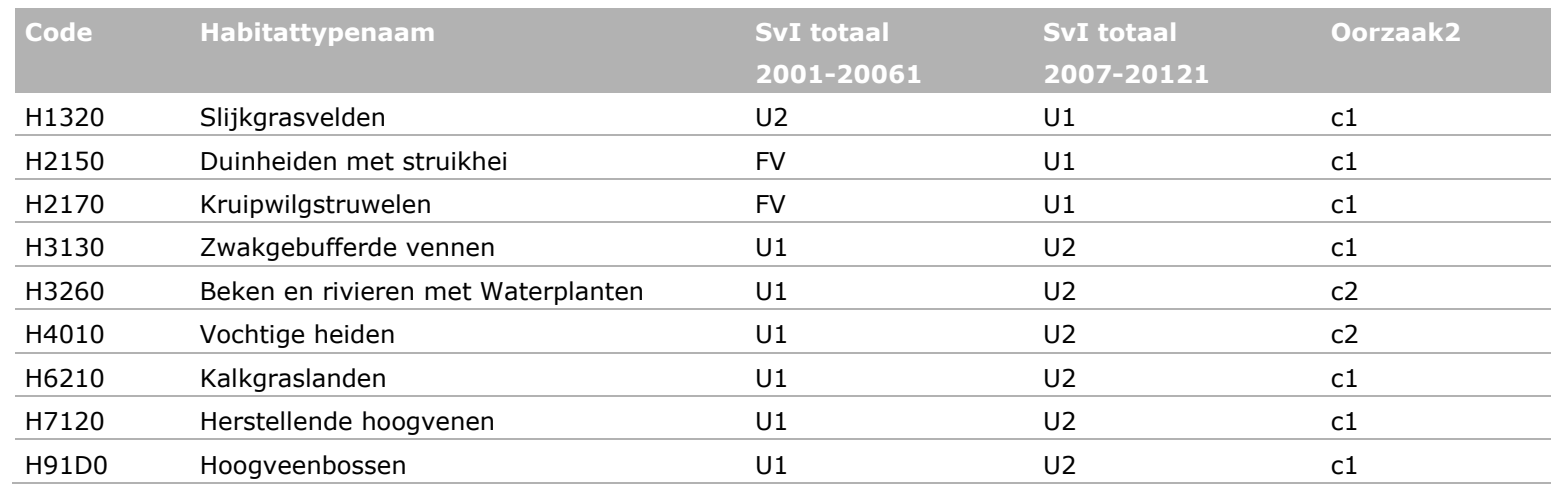

$1 \mathrm{FV}=$ Favourable (gunstig); U1 = Unfavourable-Inadequate (matig ongunstig); U2 = Unfavourable-Bad (zeer ongunstig).

2 Oorzaak: $\mathrm{c} 1$ = andere methode van meten of beoordeling individuele parameter of gehele svi; $c 2$ = gebruik van andere drempelwaarden, bijv. gunstige referentiewaarden.

\section{HR-soorten}

De staat van instandhouding is voor 21 HR-soorten gelijk gebleven, voor 5 soorten is in 2013 een betere staat van instandhouding gerapporteerd en voor 9 soorten een slechtere (zie Tabel 14). In zes gevallen gaat het om een daadwerkelijke verandering. In de overige gevallen is de verandering te verklaren door verschillen in de toegepaste methoden of betere gegevens.

Tabel 15 De staat van instandhouding van Habitatrichtlijnsoorten voor de periode 2001-2006 en de periode 2007-2012.

\begin{tabular}{|c|c|c|c|}
\hline \multirow[t]{2}{*}{ Soortnaam } & SvI totaal & SvI totaal & \multirow[t]{2}{*}{ Oorzaak* } \\
\hline & 2001-20061 & 2007-2012* & \\
\hline Kamsalamander & U1 & $\mathrm{FV}$ & a \\
\hline Gevlekte witsnuitlibel & U2 & $\mathrm{FV}$ & a \\
\hline Groenknolorchis & U2 & U1 & $\mathrm{c} 2$ \\
\hline Meervleermuis & U1 & FV & $\mathrm{c} 1$ \\
\hline Bruinvis & U2 & U1 & $\mathrm{a}$ \\
\hline Vliegend hert & U1 & U2 & $\mathrm{e}$ \\
\hline Tonghaarmuts & $\mathrm{U} 1+$ & $\mathrm{U} 2$ & $\mathrm{c} 2$ \\
\hline Drijvende waterweegbree & U1 & $\mathrm{U} 2$ & $\mathrm{c} 2$ \\
\hline Grote modderkruiper & U1 & U2 & $\mathrm{c} 2$ \\
\hline Rivierdonderpad & U1 & U2 & a \\
\hline Zeeprik & U1 & U2 & $\mathrm{c} 2$ \\
\hline Ingekorven vleermuis & FV & $\mathrm{U} 2$ & $\mathrm{c} 2$ \\
\hline Nauwe korfslak & U1 & $\mathrm{U} 2$ & $\mathrm{a}$ \\
\hline Gewone zeehond & FV & U1 & a \\
\hline
\end{tabular}

\section{VR-soorten}

De 'indicatieve' staat van instandhouding van 15 broedvogels is veranderd tussen 2006 en 2015 (zie Tabel 16). In 19 gevallen gaat het om een verbetering en in 5 gevallen om een verslechtering. Zie Foppen et al. (2016) voor details over het vaststellen van de indicatieve Staat van Instandhouding. 
Tabel 16 De 'indicatieve' staat van instandhouding van Vogelrichtlijnsoorten tussen 2006 en 2015 : broedvogels.

\begin{tabular}{|c|c|c|c|}
\hline Soortnaam & I-SvI totaal 2006* & I-SvI totaal 2015* & Oorzaak** \\
\hline Purperreiger & U2 & FV & $\mathrm{a}$ \\
\hline Dwergstern & U2 & FV & $\mathrm{a}$ \\
\hline Snor & U2 & FV & a \\
\hline Rietzanger & U1 & FV & a \\
\hline Bruine Kiekendief & $\mathrm{FV}$ & U1 & $\mathrm{a}$ \\
\hline Grauwe Kiekendief & U2 & U1 & a \\
\hline Bontbekplevier & U2 & U1 & $a$ \\
\hline Grote Stern & U2 & U1 & $\mathrm{a}$ \\
\hline Visdief & U1 & U2 & $\mathrm{a}$ \\
\hline Noordse Stern & $\mathrm{FV}$ & U2 & $\mathrm{a}$ \\
\hline
\end{tabular}

* FV = Favourable (gunstig); U1 = Unfavourable-Inadequate (matig ongunstig); U2 = Unfavourable-Bad (zeer ongsunstig).

** Oorzaak: $\mathrm{a}=$ werkelijke verandering.

De 'indicatieve staat van instandhouding' van 24 trekkende watervogels is veranderd tussen 2005 en 2015 (zie Tabel 17), waarvan in 18 gevallen een daadwerkelijk verandering. In 13 gevallen gaat het om een verbetering en in 5 gevallen om een verslechtering.

Tabel 17 Veranderingen in de 'indicatieve' staat van instandhouding van Vogelrichtlijnsoorten tussen 2006 en 2015: trekkende watervogels.

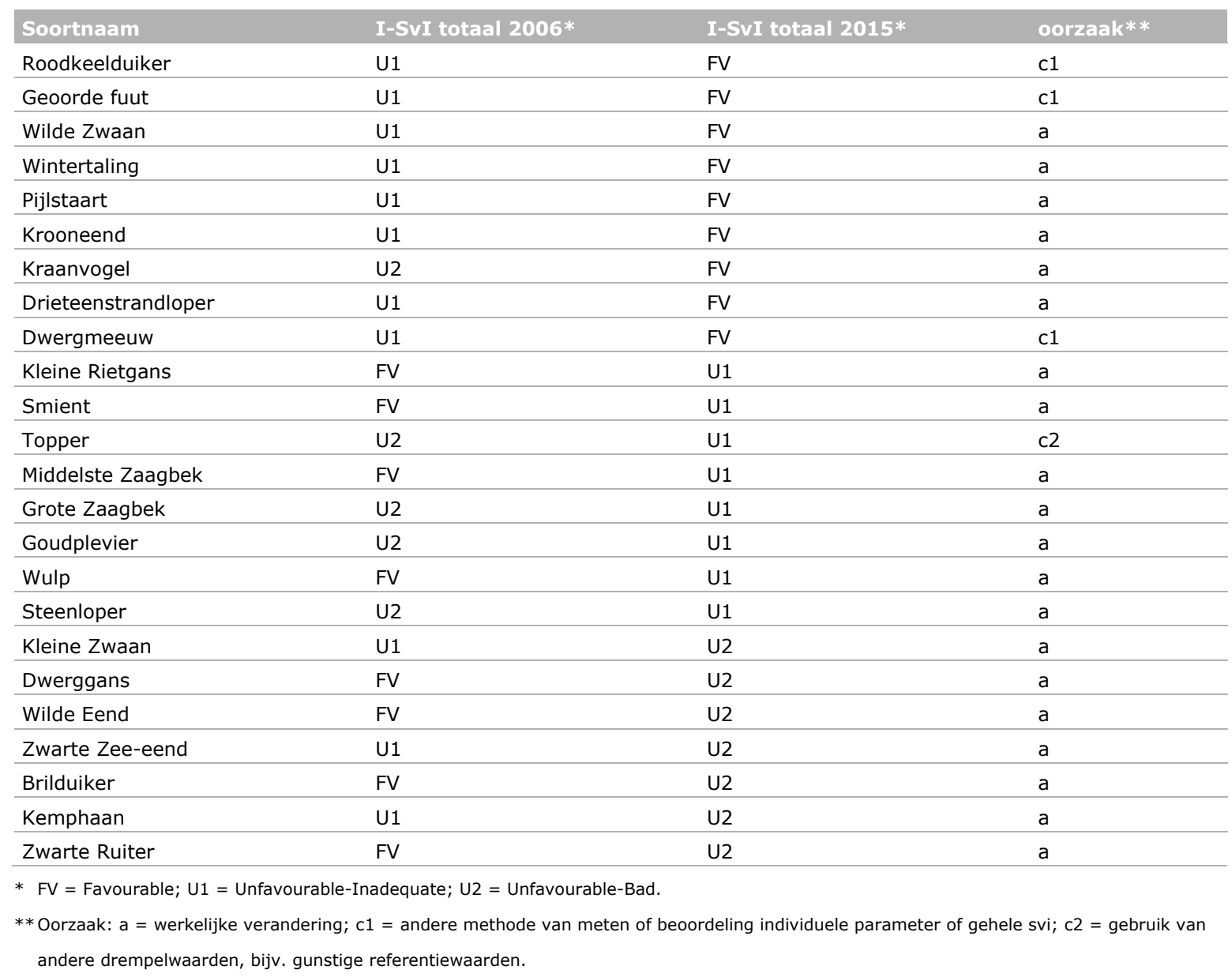




\subsubsection{Bijstellingen landelijke instandhoudingsdoelen t.a.v. populatiegrootte VR-soorten}

\section{VR-soorten}

Voor twee broedvogelsoorten, kleine en grote zilverreiger, waarvoor nog geen kwantitatief doel was gesteld in het Natura 2000-doelendocument, wordt een kwantitatieve landelijke populatiedoelstelling voorgesteld (zie Van Kleunen et al 2016). Van twaalf broedvogelsoorten is in de afgelopen jaren de oorspronkelijke landelijke doelstelling uit het Natura 2000-doelendocument aangepast, soms voor de omvang of kwaliteit van het leefgebied, soms voor de populatiedoelstelling. Van die twaalf soorten worden in Van Kleunen et al. (2016) de achtergronden van de wijzigingen toegelicht.

Voor vier niet-broedvogelsoorten waarvoor nog geen kwantitatief doel was gesteld, wordt een kwantitatieve landelijke populatiedoelstelling voorgesteld (roodkeelduiker, parelduiker, dwergmeeuw en zeekoet), zie van Kleunen et al. (2016). Voor drie soorten (topper, scholekster en kanoet) is de huidige landelijke doelstelling zoals door het ministerie gehanteerd anders dan in het Natura 2000doelendocument geformuleerd. In Van Kleunen et al. (2016) staat aangegeven welke verschillen er zijn en welk landelijk doel wordt voorgesteld. Aanvullend wordt voor vijf soorten voorgesteld om de doelen als seizoensgemiddelden, conform de andere soorten, uit te drukken in plaats van seizoensmaxima, zie details in Van Kleunen et al. (2016). Van één soort (taigarietgans) wordt een nieuw lager doel voorgesteld, omdat er in het verleden problemen bleken te zijn met de determinatie van deze soort, zie Van Kleunen et al. (2016) voor een toelichting. En dan zijn er nog 47 nietbroedvogelsoorten waarvoor voorstellen worden gedaan om de landelijke doelen, die nu gebaseerd zijn op de aantallen in alleen de gebieden van het watervogelmeetnet, om te zetten naar de werkelijke populatieaantallen in heel Nederland. Dit om misverstanden te voorkomen over welke aantallen nu bij de landelijke doelen horen. Deze verandering is geen verzwaring van de landelijke doelen, maar een versimpeling voor toetsingen. Bovendien wordt voorgesteld een aantal landelijke doelen af te ronden om de suggestie van schijnnauwkeurigheden op te heffen (Van Kleunen et al. 2016).

\subsubsection{Ecologische haalbaarheid landelijke instandhoudingsdoelen t.a.v. populatiegrootte VR-soorten}

\section{VR-soorten}

De ecologische haalbaarheid van de landelijke doelen voor vogels is onderzocht door Foppen et al. (2016). Het blijkt dat er voor veel vogelsoorten nog grote knelpunten zijn om de landelijke instandhoudingsdoelen te halen (zie Figuur 17) en dat deze voor de broedvogelpopulaties moeilijker te halen zijn dan voor de niet-broedvogelpopulaties (zie Figuur 17). Op ecologische gronden zijn die knelpunten echter wel oplosbaar, zeker op de langere termijn (2044 of later), omdat veel knelpunten toch vooral met oorzaken hier in Nederland zelf samenhangen die in principe met beheer en inrichting kunnen worden aangepakt.

De voorzichtige conclusie kan dan ook worden getrokken dat er, uitgaande van de studie van Foppen et al. (2016), geen aanleiding is om de instandhoudingsdoelen op dit moment te veranderen.

Algemeen wordt aangenomen dat door klimaatverandering ranges zullen gaan verschuiven en dat dit op termijn kan/zal moeten leiden tot aanpassingen van de Natura 2000-doelen. Op dit moment is echter de verstrengeling van lokale oorzaken met eventuele gevolgen van klimaatverandering bij deze soorten nog zo groot dat niet nu al gezegd kan worden dat doelen permanent niet meer haalbaar zijn vanwege klimaatverandering. Dit komt onder meer omdat niet uitgesloten is dat negatieve effecten van klimaatverandering eventueel kunnen worden gecompenseerd door verbeteringen in bijvoorbeeld de kwaliteit en omvang van het leefgebied (=adaptatiestrategie). In het geval van trekkende watervogels moet de oorspronkelijke draagkracht (en dus ook het doel) blijven bestaan in die gevallen dat soorten hun range naar het noorden hebben verschoven. Tijdens een onverwacht strenge winter, die ook in de toekomst binnen de trendmatige verandering van het klimaat kan optreden, zullen de populaties weer naar Nederland uitwijken waar dan wel het leefgebied nog in voldoende omvang en kwaliteit aanwezig moet zijn. Maar ook voor veel trekkende watervogels zijn het meestal lokale oorzaken die het niet halen van het doel veroorzaken. Ook zijn er geen landelijke veranderingen als gevolg van natuurlijke dynamiek vastgesteld die het behalen van doelen niet meer mogelijk maken. Een belangrijke potentiële verandering is de afname in eutrofiëring (al was de toename daarvan natuurlijk niet natuurlijk). Dit speelt vooral in de Rijkswateren, terwijl in andere kleinere wateren en 
op het land de aanwezige eutrofiëring nog een belangrijke drukfactor is. In de Rijkswateren heeft een toename van de voedselrijkdom in veel gevallen geleid tot een afname in diversiteit waarbij veel soorten zijn benadeeld en enkele hebben geprofiteerd. Bij een terugkeer naar natuurlijke voedselrijkdom kan bij deze soorten het belang van andere drukfactoren toenemen waarvan het effect door de eutrofiëring werd gemaskeerd. Bij een aantal soorten kan gebrek aan habitatdiversiteit en dynamiek (in wetlands) leiden tot situaties waarin door afname van eutrofiëring hun oude stapelvoedsel verdwijnt, zonder dat de natuurlijke diversiteit in het voedselaanbod zich herstelt. Voor de soorten die nu als gevolg van een afname van de eutrofiëringsdruk mogelijk in de problemen komen, wordt een toename in habitatdiversiteit en dynamiek in wetlands voldoende geacht om het doelbereik ecologisch haalbaar te achten. Op gebiedsniveau kunnen natuurlijke veranderingen in dynamiek wel de oorzaak zijn dat doelen op ecologische gronden niet meer haalbaar zijn. In dit verband zijn er ook spanningsvelden tussen bestaande instandhoudingsdoelen op gebiedsniveau en voortgaande verzoeting of weer verzilting van gebieden.

Figuur 16 Ecologische haalbaarheid landelijke doelen voor vogelsoorten waarvoor Natura 2000gebieden zijn aangewezen. Weergegeven is het percentage soorten waarvoor het mogelijk is in 2027 of op de langere termijn (2044 of later) de gunstige indicatieve Staat van Instandhouding te halen (ja), onzeker (ja/nee) of niet (nee). 


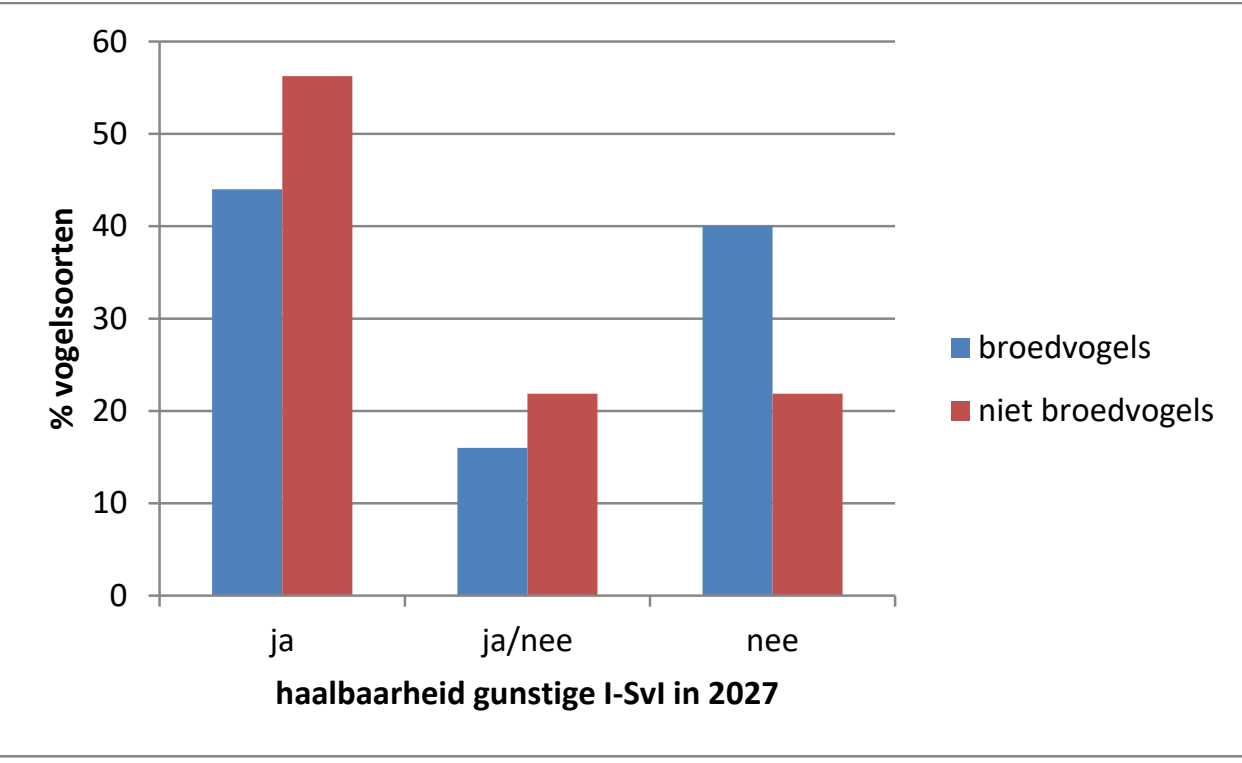

Figuur 17 Inschatting Ecologische haalbaarheid landelijke doelen voor Broedvogelsoorten of Nietbroedvogelsoorten waarvoor Natura 2000-gebieden zijn aangewezen in 2027. Weergegeven is het percentage broedvogelsoorten of niet-broedvogelsoorten waarvoor het mogelijk is in 2027 de gunstige indicatieve Staat van Instandhouding te halen (ja), onzeker (ja/nee) of niet (nee).

\subsubsection{Gebiedsdoelen}

\subsubsection{Selectie gebieden voor 'nieuwe' habitattypen en soorten}

\section{Habitattypen}

Voor het nieuwe habitattype Riffen van open zee (H1170) zal het gebied Klaverbank worden aangewezen. Voor de habitattypen die, op basis van vergelijking tussen de Nederlandse interpretatie met die in omringende landen, eventueel ook in Nederland onderscheiden kunnen worden (zie paragraaf 4.3.1.1), moet overwogen worden of de definities worden aangepast en toegepast. Het zou goed zijn om hierbij tevens te streven naar betere afstemming van definities met andere landen, op zijn minst binnen de Atlantische regio.

\section{HR-soorten}

Voor de otter wordt voorgesteld om deze aan 27 bestaande Natura 2000-gebieden als doel toe te voegen (zie Van Kleunen et al., 2016). Voor de brede geelgerande waterroofkever wordt dit voor 2 bestaande Natura 2000-gebieden geadviseerd (zie Van Kleunen et al., 2016).

\section{$V R$-soorten}

Van de geanalyseerde vogelsoorten (zie 4.3.1.1.) komen op grond van recente data over hun voorkomen en talrijkheid 19 nieuwe soorten (populaties) in aanmerking voor aanwijzing in Natura 2000-gebieden (zie Tabel 17). Het gaat om 9 soorten van Annex I, 4 soorten trekkende watervogels en 6 soorten overige trekvogels van de Rode Lijst. Bij 6 soorten gaat het om broedpopulaties en bij 13 om doortrekkers en/of overwinteraars. Het totaal aantal soort-gebiedscombinaties dat in aanmerking zou komen, is 81 . Bij 25 daarvan gaat het om een broedvogelfunctie, bij 36 om een foerageerfunctie, bij 14 om een slaapplaatsfunctie en bij 6 om zowel een foerageer- als slaapplaatsfunctie.

Deze 81 soort-gebiedscombinaties vallen in 37 reeds aangewezen gebieden en vijf nieuwe: Onlanden Groningen (deels Vogelrichtlijngebied), Lonnekerberg en Lonnekerveld e.o., Singraven e.o. bij Denekamp, Zo-Achterhoek exclusief Bekendelle, Bergumermeer - De Leijen (Van Kleunen et al. 2016). 
Tabel 18 Overzicht van de nieuwe VR-soorten (populaties) die in aanmerking komen om te worden aangewezen aan een of meerdere Vogelrichtlijngebieden. Tevens wordt het aantal gebieden genoemd waarbij onderscheid wordt gemaakt tussen reeds aangewezen Vogelrichtlijngebieden en gebieden die nog niet zijn aangewezen.

\begin{tabular}{|c|c|c|c|c|}
\hline \multirow[b]{2}{*}{ Soortnaam } & \multirow[b]{2}{*}{ type populatie } & \multirow[b]{2}{*}{ Status } & \multicolumn{2}{|c|}{ Vogelrichtlijngebieden (aantal) } \\
\hline & & & bestaand & nieuw \\
\hline Blauwe Kiekendief & doortrekker/wintergast & terrestrische trekvogel Rode Lijst & 5 & \\
\hline Buidelmees & Broedvogel & terrestrische trekvogel Rode Lijst & 5 & \\
\hline Dwergstern & Doortrekker & Annex 1 & 1 & \\
\hline Grote Stern & Doortrekker & Annex 1 & 1 & \\
\hline Kleinst Waterhoen & Broedvogel & Annex 1 & & 1 (deels VR)* \\
\hline Kokmeeuw & doortrekker/wintergast & trekkende watervogel & 9 & \\
\hline Kraanvogel & Broedvogel & Annex 1 & 1 & \\
\hline Regenwulp & Doortrekker & trekkende watervogel & 1 & \\
\hline Ruigpootbuizerd & Wintergast & terrestrische trekvogel Rode Lijst & 1 & \\
\hline Sneeuwgors & doortrekker/wintergast & terrestrische trekvogel Rode Lijst & 5 & \\
\hline Stormmeeuw & doortrekker/wintergast & trekkende watervogel & 11 & 1 \\
\hline Strandleeuwerik & doortrekker/wintergast & terrestrische trekvogel Rode Lijst & 1 & \\
\hline Visdief & Doortrekker & Annex 1 & 3 & \\
\hline Zilvermeeuw & Wintergast & trekkende watervogel & 8 & \\
\hline
\end{tabular}

\subsubsection{Bijstelling selectie gebieden voor 'bestaande' habitattypen en soorten}

\section{Habitattypen}

Aan de al 980 bestaande habitattype-gebiedscombinaties wordt geadviseerd om 202 nieuwe habitattype-gebiedscombinaties toe te voegen. Van de 980 bestaande habitattype-gebiedscombinaties wordt geadviseerd om 10 habitattype-gebiedscombinaties te schrappen (Van Kleunen et al., 2016).

HR-soorten

Voor 26 'bestaande' HR-soorten wordt geadviseerd om deze aan een of meer al bestaande Natura 2000-gebieden toe te voegen. In totaal gaat het om 83 soort-gebiedscombinaties. Verder wordt er voor 6 soort-gebiedscombinaties het advies gegeven deze te schrappen (Van Kleunen et al., 2016).

\section{$V R$-soorten}

Er komen op dit moment 393 soort-gebiedscombinaties in aanmerking om te worden aangewezen voor een of meerdere Vogelrichtlijnsoorten op grond van recente data van hun voorkomen en talrijkheid (zogenaamde important birds areas - IBA's, belangrijke vogelgebieden). Het gaat om 25 soorten van Bijlage 1 en 35 soorten trekkende watervogels (niet Bijlage 1). Bij 26 soorten gaat het om broedvogels en bij 40 soorten om doortrekkers en/of overwinteraars (Van Kleunen et al., 2016).

Tussen die gebieden, waarvoor nu soorten kwalificeren, zitten voor broedvogels twee gebieden die nog niet zijn aangewezen als Vogelrichtlijngebied: Rotte Meren en Zevenhuizerplas en de kreken van oostelijk Zeeuws-Vlaanderen. Voor de trekkende watervogels zijn er 77 nieuwe gebieden die op grond van de aantalscriteria in aanmerking komen voor aanwijzing. Deze gebieden zullen nog wel moeten worden getoetst aan de gebiedscriteria (LNV, 2000). Bij toepassing van deze criteria vallen waarschijnlijk gebieden af, bijvoorbeeld omdat ze niet aan het criterium voor het areaal beschermd natuurgebied voldoen (zie Van Kleunen et al. 2016 voor meer toelichting). 
Voor 2 broedvogelsoort-gebiedscombinaties wordt voorgesteld de populatiedoelstelling te wijzigen. Voor 147 niet-broedvogelsoort-gebiedscombinaties wordt aangegeven dat de huidige populatiedoelstelling voor de foerageer- en of slaapplaatsfunctie zou moeten worden aangepast vanwege uiteenlopende redenen (Van Kleunen et al. 2016).

\title{
4.4 Conclusies en aanbevelingen
}

\author{
4.4.1 Landelijke doelen
}

\subsubsection{Selectie van 'nieuwe' habitattypen en soorten}

\section{Habitattypen}

$\mathrm{Er}$ is in de tussentijd één habitattype, te weten Riffen van open zee, aan de huidige selectie van habitattypen voor Nederland toegevoegd. Hiervoor wordt het gebied Klaverbank aangewezen. Verder is er een viertal habitattypen, dat vanwege nieuwe inzichten over definities, in aanmerking komt ook in Nederland te onderscheiden, een tweetal vloedmerkvegetaties (H1210 en H1220) en een tweetal Midden-Europese Beukenbossen (H9130 en H9150). Hiervoor hoeven geen extra gebieden aangewezen te worden. Mogelijk moet hierbij soms wel de begrenzing net iets aangepast worden om deze locaties binnen het Natura 2000-netwerk te krijgen, maar dit is niet in detail uitgezocht. Van een aantal habitattypen zijn in de tussentijd de definities veranderd, hetgeen tot consequenties kan leiden voor de selectie en de beoordeling van het relatieve belang van de hiervoor aangewezen gebieden. Binnen dit onderzoek zijn deze consequenties ingeschat, maar is het relatieve belang (nog) niet aangepast (zie voor meer details Van Kleunen et al., 2016).

\section{HR-soorten}

Er is een vijftal HR-soorten dat (her)nieuw(d) in Nederland voorkomt, te weten de mercuurwaterjuffer, de vermiljoenkever, de bechsteinvleermuis, de otter en de brede geelgerande waterroofkever. De laatste twee voldoen aan het criterium dat ze meer dan tien jaar in Nederland aanwezig zijn en daarom zouden voor deze soorten ook gebieden geselecteerd en aangewezen moeten worden (voor meer details zie Van Kleunen et al., 2016).

\section{VR-soorten}

Op basis van de criteria voor de selectie van vogelsoorten waarvoor Natura 2000-gebieden kunnen worden aangewezen, komen 19 nieuwe soorten ( 6 broedvogels +13 doortrekkers/overwinteraars conform artikel 4.2 in aanmerking om een of meerdere gebieden in Nederland te selecteren. Het gaat in totaal om 81 soort-gebiedscombinaties en deze bevinden zich in 37 reeds aangewezen gebieden en 5 nieuwe.

In de huidige criteria voor selectie van vogelsoorten (ministerie van Landbouw, Natuur en Voedselkwaliteit, 2000) is niet duidelijk gedefinieerd wanneer er sprake is van vaste verblijfplaatsen en geconcentreerd voorkomen. Deze keuze is nu op basis van expert judgement gemaakt. Het hanteren van concretere grenswaarden hiervoor is aan te raden, want dit maakt het selectieproces transparanter.

Voor een aantal aanwijssoorten, waaronder grutto, geldt dat ze alleen zijn aangewezen als nietbroedvogel, terwijl de niet-broedvogels vooral Nederlandse broedvogels betreffen. De ongunstige indicatieve staat van instandhouding kan verklaard worden door omstandigheden in de broedgebieden. Het verdient daarom aanbeveling om te kijken of voor de soorten waarvoor dit geldt gebieden voor de broedvogelfunctie kunnen worden aangewezen.

\subsubsection{Actualisatie relatieve belang Nederland binnen EU, de Atlantische regio en de Oost-Atlantische vliegroute voor 'bestaande' habitattypen en soorten}

Voor een vrij groot aantal habitattypen en HR- en VR-soorten is het belang van Nederland voor de EU aangepast (zie paragraaf 4.3.1.2). Het relatieve belang geeft (naast de ligging in het verspreidingsgebied) inzicht in de mate waarin Nederland kan bijdragen aan het halen van de staat 
van instandhouding van een habitattype of soort in het Europese netwerk. In Nederland wordt een groot relatief belang daarom meegewogen bij het stellen van een hersteldoel (ministerie van Landbouw, Natuurbeheer en Visserij, 2006). In theorie zou op basis van het veranderde relatieve belang mogelijk ook sommige hersteldoelen moeten worden aangepast. In de praktijk zijn de veranderingen niet zodanig groot dat van een echt andere Nederlandse verantwoordelijkheid sprake is en wordt aangeraden niet op basis van dit criterium de hersteldoelen te veranderen.

\subsubsection{Actualisatie van de staat van instandhouding van 'bestaande' habitattypen en soorten}

De veranderingen in de staat van instandhouding van habitattypen en HR-soorten zijn grotendeels te verklaren door veranderingen in methodiek en/of gegevens. Voor de Vogelrichtlijnsoorten is de actuele 'indicatieve' staat van instandhouding bepaald, welke kan worden vergeleken met de staat van instandhouding uit het Natura 2000-doelendocument. Deze vergelijking laat voor broedvogels een voorzichtig positief beeld zien: het aantal soorten met een gunstige indicatieve staat van instandhouding is licht toegenomen en dat met een zeer ongunstige indicatieve staat van instandhouding licht afgenomen. Hetzelfde geldt voor de niet-broedvogels, waarbij er meer verbeteringen in de indicatieve staat van instandhouding zijn dan verslechteringen (Foppen et al., 2016). Aanbevolen wordt om ook voor de VR-soorten een beoordeling uit te (blijven) voeren van de staat van instandhouding om de voortgang van het Natura 2000-beleid te kunnen evalueren.

\subsubsection{Bijstelling landelijke doelen populatiegrootte VR-soorten}

Voor de VR-soorten waar nog geen kwantitatief doel was gesteld, worden die nu wel voorgesteld. Voor de taigarietgans wordt een nieuw doel voorgesteld, omdat er betere informatie beschikbaar is gekomen over het voorkomen van de soort in Nederland. Voorts is het nu mogelijk om voor meer soorten watervogels het doel uit te drukken in seizoensgemiddelden in plaats van seizoensmaxima. Ten slotte zijn voor watervogels doelen berekend op basis van de werkelijke aantallen in Nederland in plaats van die in de monitoringgebieden van het Watervogelmeetnet. Geadviseerd wordt om deze nieuwe doelen over te nemen.

\subsubsection{Ecologische haalbaarheid landelijke doelen t.a.v. populatiegrootte VR-soorten} De analyse van de ecologische haalbaarheid van de VR-soorten laat zien dat momenteel alle gestelde landelijke doelen vanuit ecologisch perspectief zeker op lange termijn haalbaar lijken. Momenteel zijn de gevolgen van klimaatverandering dermate verstrengeld met andere (ecologisch oplosbare) factoren dat nu nog niet gezegd kan worden dat doelen vanuit het oogpunt van klimaatverandering onhaalbaar zijn.

\subsubsection{Gebiedsdoelen}

\subsubsection{Selectie gebieden voor 'nieuwe' habitattypen en soorten}

Sinds de aanmelding (en aanwijzing) van Natura 2000-gebieden met de bijbehorende natuurwaarden is er het een en ander veranderd aan het voorkomen en de verspreiding van habitattypen en soorten. In bepaalde gebieden zijn bijvoorbeeld spontaan (brede geelgerande waterroofkever) of door herintroductie (otter) nieuwe Bijlage II-soorten opgedoken waarvoor gebieden zouden moeten worden aangewezen. Anderzijds is er sprake van natuurlijke dynamiek, nieuwe inzichten en aanvullende of nieuwe (verspreidings)gegevens, waardoor de doelen voor de afzonderlijke habitattypen en soorten in bepaalde gevallen zouden moeten worden bijgesteld. Ook is in enkele gevallen de staat van instandhouding gewijzigd, soms beter, vaker slechter. Dit kan het gevolg zijn van een echte verandering, maar ook (vaker) van betere databeschikbaarheid, een andere evaluatiemethode, gebruik van andere drempelwaarden, minder precieze of juist betere waarnemingen of afwezigheid van data. Een en ander zou gevolgen kunnen hebben voor de landelijke doelstelling en daarmee ook de gebiedsdoelstellingen.

Aanbevolen wordt om Natura 2000-gebieden aan te wijzen voor het nieuwe habitattype en de HRsoorten en VR-soorten, die conform de huidige, geldende criteria hiervoor in aanmerking komen. Dit wordt uitgebreid toegelicht in het technische achtergrondrapport en is ook verwerkt in een overzicht in Excel (Van Kleunen et al., 2016). 
Voor een deel van de VR-soorten kon de analyse van de aan te wijzen gebieden niet worden uitgevoerd, omdat er geen gebiedsdekkende teldata waren. Daarom stellen we voor om, zeker voor niet-vlakdekkende op gebiedsniveau onderzochte VR-soorten, in de toekomst ook gebruik te gaan maken van gemodelleerde abundantiekaarten, die bruikbaar zijn om op gebiedsniveau aantalsschattingen te maken (zeker bij het beschikbaar komen van de Broed- en Wintervogelatlas 2012-2015, www.vogelatlas.nl).

Voor enkele zeldzame broedvogels die van nature in lage dichtheden in grote gebieden voorkomen, zoals de zeearend en oehoe is het lastig om met de huidige aanwijscriteria gebieden te selecteren. Zo geldt een ondergrens van minimaal twee broedparen. Op gebiedsniveau komt dit weinig voor in Nederland. Geëvalueerd zou moeten worden of dit criterium voor dergelijke soorten kan worden bijgesteld of kan worden toegepast op een regio (cluster van Natura 2000-gebieden).

De huidige aanwijssystematiek biedt de mogelijkheid om bedreigde broedvogels (die op grond van de andere criteria buiten de boot vallen) aan die gebieden toe te voegen die ook voor andere vogelsoorten zijn geselecteerd. Wij stellen voor om dit ook mogelijk te maken voor bedreigde doortrekkers en overwinteraars. De soorten die het momenteel betreft, staan in paragraaf 4.3.2.1 genoemd.

\subsubsection{Selectie gebieden voor 'bestaande' habitattypen en soorten}

Aanbevolen wordt om de huidige selectie van Natura 2000-gebieden bij te stellen voor een aantal bestaande habitattypen en soorten. Dit gaat om 212 habitattype-gebiedscombinaties (202 erbij en 10 eraf), 101 HR-soort-gebiedscombinaties (83 erbij en 6 eraf) en 396 VR-soort-gebiedscombinaties (396 erbij). Hierbij zitten in totaal 79 nog niet aangewezen gebieden, waarbij opgemerkt moet worden dat mogelijk veel gebieden niet in aanmerking zullen komen voor aanwijzing op grond van gebiedscriteria.

Voor de soort-gebiedscombinaties waarvoor dit naar alle waarschijnlijk gaat worden doorgevoerd, wordt aangeraden om deze soorten al wel in de lopende monitoringprojecten (waaronder de slaapplaatstellingen) mee te nemen.

Gezien de aanbevelingen uit de evaluatie van de Natura 2000-doelensystematiek is het de vraag welk moment in het huidige aanwijzings- en beheerplanproces hiervoor het geschiktst is.

\subsubsection{Bijstelling gebiedsdoelen t.a.v. populatiegrootte VR-soorten}

Net als voor de landelijke doelen zijn zo veel mogelijk kwantitatieve doelen bepaald voor soortgebiedscombinaties waarvoor nu al kwalitatieve doelen bestaan. Bij watervogels is waar mogelijk een doel bepaald op basis van seizoensgemiddelden in plaats van seizoensmaxima. Voorts zijn voor een set slaapplaatsfuncties kwantitatieve doelen berekend. Ten slotte wordt voor een klein aantal soortgebiedcombinaties voorgesteld om de foerageer- dan wel slaapplaatsfunctie te laten vallen als deze in de praktijk niet relevant blijkt voor het betreffende gebied (Van Kleunen et al. 2016).

Bij de uitgevoerde analyse van nieuwe aan te wijzen gebieden is uitgegaan van de begrenzing van bestaande Vogelrichtlijngebieden. Wij raden aan om te kijken of nabij bestaande Vogelrichtlijngebieden gelegen terreinen met grote aantallen van aanwijssoorten (bijvoorbeeld door recente natuurontwikkeling) kunnen worden toegevoegd aan het nabijgelegen Vogelrichtlijngebied. Een voorbeeld van zo'n geval is het natuurontwikkelingsgebied Utopia in het noorden van Texel, dat aan het bestaande Vogelrichtlijngebied Duinen en Lage land van Texel zou kunnen worden toegevoegd voor dwergstern, noordse stern, visdief en grote stern. 


\section{Literatuur}

Bijlsma, R.J., A.J.M. Jansen, J.A.M. Janssen, G.J. Maas en P.C. Schipper (2016) Kansen voor meer natuurlijkheid in Natura 2000-gebieden. Wageningen Environmental Research rapport 2745, Wageningen Environmental Research, Wageningen.

Bijlsma, R.J., J.A.M. Janssen, E.J. Weeda en J.H.J. Schaminée (2014a) Gunstige referentiewaarden voor oppervlakte en verspreidingsgebied van Natura 2000-habitattypen in Nederland. WOt-rapport 125. WOT Natuur \& Milieu - Wageningen UR, Wageningen.

Bijlsma, R.J., J.A.M. Janssen, F.G.W.A. Ottburg, C.A.M. van Swaay en E.J. Weeda (2014b) Haalbaarheid van gunstige referentiewaarden. Een oriënterende studie in het kader van de evaluatie van Natura 2000-doelen. Alterra-rapport (intern EZ), Alterra, Wageningen.

Broekmeyer, M.E.A. en M. Pleijte (2016) Kansen en knelpunten bij de uitvoering van de Europese Vogelrichtlijn en Habitatrichtlijn. Alterra-rapport 2705. Alterra, Wageningen.

Europese Commissie (2012) Commission note on setting conservation objectives for Natura 2000 sites, European Commission, Final version 23/11/2012.

Europese Commissie (2011a) Assessment and reporting under Article 12 of the Bird Directive. Reporting Formats for the period 2008-2012, July 2011.

Europese Commissie (2011b) Assessment and reporting under Article 12 of the Birds Directive. Explanatory Notes \& Guidelines for the period 2008-2012. Final Version December 2011. Compiled by the N2K Group under contract to the European Commission.

Europese Commissie (2011c) Assessment and reporting under Article 17 of the Habitats Directive. Reporting Formats for the period 2007-2012, May 2011.

Europese Commissie (2011d) Assessment and reporting under Article 17 of the Habitats Directive Explanatory Notes \& Guidelines for the period 2007-2012. Final version. July 2011. Compiled by Douglas Evans and Marita Arvela of the European Topic Centre on Biological Diversity.

Europese Commissie (2011e) UITVOERINGSBESLUIT VAN DE COMMISSIE van 11 juli 2011 betreffende een gebiedsinformatieformulier voor Natura 2000-gebieden C(2011) 4892 (2011/484/EU).

Janssen, J., E. Weeda, P. Schipper, R-J. Bijlsma, J. Schaminée, C. Deerenberg, O. Bos, R. Jak (2014) Habitattypen in Natura 2000-gebieden. Beoordeling van oppervlakte, representativiteit en behoudsstatus in de Standard Data Forms (SDF), WOt technical report 8. WOT unit Natuur en Milieu, Wageningen.

Foppen, R., M. Roomen, L. Bremer, R. Noordhuis (2016) De ecologische haalbaarheid van de Natura 2000 instandhoudingsdoelen voor vogels. Een studie in het kader van project 'Evaluatie Natura 2000-doelen'. Sovon-rapport nr. 16, Sovon.

Kleunen, van A., M. van Roomen, Janssen, J.A.M., L. Kuiters, E. van Winden, A. Boele, T. van Vreeswijk en A.M. Schmidt (2016) Advies over correcties en bijstellingen van Natura 2000doelen. Achtergronddocument bij het rapport Advies over de Natura 2000-doelensystematiek en Natura 2000-doelen. Wageningen Environmental Research-rapport 2779C, Wageningen Environmental Research, Wageningen.

Kleunen, A. van, M. van Roomen, L. van den Bremer, A. Lemaire, J.W. Vergeer \& E. van Winden, (2014). Ecologische gegevens van vogels voor de Standaard Gegevensformulieren Vogelrichtlijngebieden. SOVON Vogelonderzoek Nederland. WOt technical report 2. WOT unit Natuur en Milieu, Wageningen.

Kleunen, van (2013) Toelichting op de geleverde vogelinformatie voor de Vogelrichtlijnrapportage 2008-2012 van Nederland. SOVON-notitie 2013-110. Sovon Vogelonderzoek, Nijmegen.

Kleunen, A. van, M. van Roomen, E. Winden, D. Zoetebier, A. Boele, H. Sierdsema, C. van Turnhout, M. Hornman \& F. Hustings (2013) Toelichting op geleverde vogelinformatie voor de Vogelrichtlijnrapportage 2008-2012. Sovon-notitie 2013-110. Sovon Vogelonderzoek Nederland, Nijmegen.

Ministerie van Economische Zaken (2014a) Rijksnatuurvisie 2014. Natuurlijk verder. Ministerie van Economische Zaken, Den Haag. 
Ministerie van Economische Zaken (2014b) Leeswijzer Natura 2000-profielen. Geheel hernieuwde versie september 2014. Ten behoeve van de profielen behorend bij de aanwijzing van de Natura 2000-gebieden. Ministerie van Economische Zaken, Den Haag.

Ministerie van Landbouw, Natuur en Voedselkwaliteit (2006) Natura 2000-doelendocument. Duidelijkheid bieden, richting geven en ruimte laten. Ministerie van Landbouw, Natuur en Voedselkwaliteit, Den Haag.

Ministerie van Landbouw, Natuur en Voedselkwaliteit (2005) Handreiking beheerplannen Natura 2000gebieden. Ministerie van Landbouw, Natuur en Voedselkwaliteit, Den Haag.

Ministerie van Landbouw, Natuur en Voedselkwaliteit (2003) Verantwoordingsdocument. Selectiemethodiek voor aangemelde Habitatrichtlijngebieden. Ministerie van Landbouw, Natuur en Voedselkwaliteit, Den Haag.

Ministerie van Landbouw, Natuur en Voedselkwaliteit (2000) Nota van antwoord Vogelrichtlijn. Ministerie van Landbouw, Natuur en Voedselkwaliteit, Den Haag.

Ottburg, F.G.W.A. \& J.A.M. Janssen (2014) Habitatrichtlijnsoorten in Natura 2000-gebieden. Beoordeling van populatie, leefgebied en isolatie in de Standard Data Forms (SDF), WOt technical report 9. WOT unit Natuur en Milieu, Wageningen.

Ottburg, F.G.W.A. en C.A.M. van Swaay (2014) Habitatrichtlijnsoorten in Nederland; Gunstige referentiewaarden voor populatiegrootte en range voor soorten van Bijlage II, IV en $\mathrm{V}$ van de Europese Habitatrichtlijn. WOt-rapport 124. WOT Natuur \& Milieu - Wageningen UR, Wageningen.

Programmadirectie Natura 2000 (2011a) Nota van Antwoord op hoofdlijnen. Achtergronddocument bij de publicatie van Natura 2000-aanwijzingsbesluiten. Ministerie van Landbouw, Natuur en Voedselkwaliteit, Den Haag.

Programmadirectie Natura 2000 (2011b) Nota van Antwoord. Inspraakprocedure aanwijzing Natura 2000-gebieden. Ministerie van Landbouw, Natuur en Voedselkwaliteit, Den Haag.

Regiebureau Natura 2000 (2009) Checklist beheerplannen Natura 2000-gebieden. Versie 24 april 2009. Regiebureau Natura 2000, Utrecht.

Roomen, M., A. Boele, M. van der Weide, E. van der Winde en D. Zoetebier (2000) Belangrijke vogelgebieden in Nederland, 1993-1997. Actueel overzicht van Europese Vogelwaarden in aangewezen en aan te wijzen beschermingszones en andere belangrijke gebieden. Sovon Vogelonderzoek Nederland, Nijmegen.

Schmidt, A.M. en A.S. Adams (2015) Documentatie Habitatrichtlijn-rapportage artikel 17, 2007-2012. WOt technical report nr. 55, WOt unit Natuur en Milieu, Wageningen.

Vreeswijk, T. van, A.M. Schmidt, A. van Kleunen, L. van den Bremer (2016) Analyse Natura 2000doelensystematiek op basis van beheerplannen van de Natura 2000-gebieden.

Achtergronddocument bij het rapport Advies over de Natura 2000-doelensystematiek en Natura 2000-doelen. Wageningen Environmental Research-rapport 2779B, Wageningen Environmental Research, Wageningen. 


\section{Bijlage 1 Criteria selectie en begrenzing Natura 2000-gebieden}

\section{Selectie- en begrenzing gebieden}

Al voor het opstellen van het Natura 2000-doelendocument zijn de Natura 2000-gebieden geselecteerd en begrensd. De Vogelrichtlijngebieden en de Habitatrichtlijngebieden kennen elk hun eigen selectiemethodiek. Deze methoden zijn opgenomen in de Nota van antwoord Vogelrichtlijn (Ministerie van Landbouw, Natuur en Voedselkwaliteit, 2000) en in het Verantwoordingsdocument (Ministerie van Landbouw, Natuur en Voedselkwaliteit, 2003). De begrenzing van de Vogelrichtlijngebieden en Habitatrichtlijngebieden is gebaseerd op verschillende (deels overlappende) uitgangspunten. Bij de in voorbereiding zijnde aanwijzing van de Habitatrichtlijngebieden en de aanvulling van de Vogelrichtlijnaanwijzingen met gebiedsdoelen zijn overlappende Vogel- en Habitatrichtlijngebieden gecombineerd tot één Natura 2000-gebied. Daarbij is ernaar gestreefd de begrenzing van Vogel- en Habitatrichtlijngebieden zo goed mogelijk op elkaar af te stemmen.

\section{Selectie en begrenzing Habitatrichtlijngebieden}

De Habitatrichtlijngebieden zijn in 2003 geselecteerd (en aangemeld) conform de selectiecriteria van Bijlage III van de Habitatrichtlijn, zie Bijlage 2. Voor elk niet-prioritair habitattype en niet-prioritaire soort zijn in principe de vijf belangrijkste gebieden geselecteerd. Voor prioritaire typen en soorten zijn in principe de tien belangrijkste gebieden geselecteerd. Indien minder dan vijf respectievelijk tien gebieden een voldoende bijdrage leveren aan de instandhouding of herstelmogelijkheden van een habitattype of soort (door voldoende kwaliteit en oppervlakte), zijn minder dan vijf gebieden geselecteerd. Bij de selectie van de Natura 2000-gebieden is ook rekening gehouden met ecologische variatie van de habitattypen, de geografische spreiding en gebieden grenzend aan Duitsland en België.

Bij de begrenzing van de Habitatrichtlijngebieden is uitgegaan van:

- habitattypen van Annex I en soorten van Annex II

- herkenbare eenheden en identiteit

- 'cement tussen bakstenen'

- deelgebieden

- aansluiting bij administratieve grenzen

- herkenbare topografische lijnen

\section{Selectie en begrenzing Vogelrichtlijngebieden}

De Vogelrichtlijngebieden zijn grotendeels in 2000 geselecteerd. Voor elke soort van Bijlage I, die geregeld vaste verblijfplaatsen in ons land heeft, zijn de vijf belangrijkste gebieden geselecteerd. Dit zijn de gebieden waar gemiddeld de grootste aantallen vogels zijn vastgesteld. Voor trekkende watervogels die niet zijn opgenomen in Bijlage I, zijn de gebieden geselecteerd die voldoen aan de 1 procent-drempelwaarde: het gebied herbergt minstens 1 procent van de biogeografische populatie. Dit criterium is ook toegepast voor 15 watervogelsoorten die in Bijlage I zijn opgenomen. Daarnaast zijn overige trekvogels van de Rode Lijst van de Nederlandse broedvogels aan reeds aangewezen Vogelrichtlijngebieden toegevoegd, als een belangrijk deel van de Nederlandse populatie ( $>25 \%)$ in Vogelrichtlijngebieden voorkomt. Voor broedvogels is voor beide criteria uitgegaan van het gemiddeld aantal broedparen in de peilperiode 1993-97. De overschrijding van de 1 procent-drempel is getoetst aan de hand van het gemiddelde seizoensmaximum in de periode 1992/93-1996/97.

Om gebieden te kunnen identificeren en te begrenzen, is een bepaalde opvatting van het begrip gebied nodig, zoals bedoeld in de Vogelrichtlijn. Hiertoe zijn de volgende uitgangspunten gehanteerd voor de definitie van een gebied:

- Het gebied onderscheidt zich in aard of ornithologische betekenis duidelijk van de omgeving.

- Het is een bestaand of potentieel bescherma gebied met of zonder bufferzones dan wel een gebied waar de vogelwaarden op enigerlei wijze beschermd kunnen worden.

- Het gebied voldoet, alleen of in combinatie met andere gebieden, aan alle vereisten die de vogels waarvoor het gebied van belang is aan hun omgeving stellen, in de periode dat ze er aanwezig zijn. 
Ligging en landschappelijke aard van een gebied zijn bepaald aan de hand van de verspreiding en de biotoopeisen van de kwalificerende soorten. De grenzen zijn bepaald aan de hand van het terreingebruik en de biotoopeisen van de aanwezige kwalificerende soorten en van de aanwezige begrenzingssoorten. 


\section{Bijlage 2 Beoordeling relatieve belang gebieden (Bijlage III van de Habitatrichtlijn)}

\section{CRITERIA VOOR DE SELECTIE VAN GEBIEDEN DIE KUNNEN WORDEN AANGEWEZEN ALS GEBIEDEN VAN COMMUNAUTAIR BELANG EN ALS SPECIALE BESCHERMINGSZONES}

\section{FASE 1 Nationale beoordeling van het relatieve belang van de gebieden voor elk type natuurlijke habitat van Bijlage I en elke soort van Bijlage II (met inbegrip van de prioritaire typen natuurlijke habitats en de prioritaire soorten).}

1. Criteria voor de beoordeling van het gebied voor een type natuurlijke habitat van Bijlage I

A. Mate van representativiteit van het type natuurlijke habitat in het gebied;

B. Door het type natuurlijke habitat bestreken oppervlakte van het gebied ten opzichte van de totale door dit type natuurlijke habitat op het nationale grondgebied bestreken oppervlakte;

C. Mate van instandhouding van de structuur en de functies van het betrokken type natuurlijke habitat en herstelmogelijkheid;

D. Algemene beoordeling van de betekenis van het gebied voor de instandhouding van het betrokken type natuurlijke habitat.

2. Criteria voor de beoordeling van het gebied voor een soort van Bijlage II

A. Omvang en dichtheid van de populatie van de soort in het gebied ten opzichte van de populaties op het nationale grondgebied;

B. Mate van instandhouding van de elementen van de habitat die van belang zijn voor de betrokken soort en herstelmogelijkheid;

C. Mate van isolatie van de populatie in het gebied ten opzichte van het natuurlijke verspreidingsgebied van de soort;

D. Algemene beoordeling van de betekenis van het gebied voor de instandhouding van de betrokken soort.

3. Volgens deze criteria delen de Lid-Staten de gebieden in die zij op de nationale lijst voorstellen als gebieden welke in aanmerking komen voor aanwijzing als gebied van communautair belang, al naar gelang van hun betekenis voor de instandhouding van de in Bijlage I genoemde typen natuurlijke habitats of de in Bijlage II genoemde soorten.

4. Deze lijst omvat de gebieden met prioritaire typen natuurlijke habitats en de prioritaire soorten die volgens de onder A en B aangegeven criteria door de Lid-Staten zijn geselecteerd.

FASE 2 Beoordeling van het communautair belang van de op de nationale lijsten geplaatste gebieden

1. Alle door de Lid-Staten in fase 1 aangewezen gebieden met prioritaire typen natuurlijke habitats en/of prioritaire soorten worden beschouwd als gebieden van communautair belang.

2. De beoordeling van het communautaire belang van de overige gebieden die voorkomen op de lijsten van de Lid-Staten, d.w.z. van de bijdrage die zij leveren tot het in een gunstige staat van instandhouding behouden of herstellen van een natuurlijke habitat uit Bijlage I of van een soort uit Bijlage II en/of de coherentie van Natura 2000, geschiedt met inachtneming van de volgende criteria:

A. de relatieve betekenis van het gebied op nationaal niveau;

B. de geografische ligging van het gebied ten opzichte van de trekroutes van diersoorten van Bijlage II, mede gelet op de vraag of het gebied eventueel deel uitmaakt van een samenhangend ecosysteem aan weerszijden van een of meer binnengrenzen van de Gemeenschap;

C. de totale oppervlakte van het gebied;

D. het aantal typen natuurlijke habitats van Bijlage I en soorten van Bijlage II in het gebied;

E. de algemene ecologische waarde van het gebied voor de betrokken biogeografische regio's en/of voor het gehele in artikel 2 bedoelde grondgebied, zowel wat betreft het karakteristieke of unieke aspect van de bestanddelen als wat betreft de combinatie daarvan. 


\section{Bijlage 3 Beoordeling staat van instandhouding}

\begin{tabular}{|c|c|c|c|c|}
\hline \multirow[t]{2}{*}{ Parameter } & & & \multicolumn{2}{|l|}{ Conservation Status } \\
\hline & $\begin{array}{l}\text { Favourable } \\
\text { ('green') }\end{array}$ & $\begin{array}{l}\text { Unfavourable - } \\
\text { Inadequate } \\
\text { ('amber') }\end{array}$ & $\begin{array}{c}\text { Unfavourable - Bad } \\
\text { ('red') }\end{array}$ & $\begin{array}{c}\text { Unknown } \\
\text { (insufficient } \\
\text { information to } \\
\text { make an } \\
\text { assessment) }\end{array}$ \\
\hline Range & $\begin{array}{l}\text { Stable (loss and } \\
\text { expansion in balance) or } \\
\text { increasing AND not } \\
\text { smaller than the } \\
\text { 'favourable reference } \\
\text { range' }\end{array}$ & $\begin{array}{l}\text { Any other } \\
\text { combination }\end{array}$ & $\begin{array}{l}\text { Large decline: Equivalent to a } \\
\text { loss of more than } 1 \% \text { per year } \\
\text { within period specified by MS } \\
\text { more than } 10 \% \text { below } \\
\text { favourable reference range }\end{array}$ & $\begin{array}{l}\text { No or insufficient } \\
\text { reliable information } \\
\text { available }\end{array}$ \\
\hline Population & $\begin{array}{l}\text { Population(s) not lower } \\
\text { than 'favourable } \\
\text { reference population' } \\
\text { AND reproduction, } \\
\text { mortality and age } \\
\text { structure not deviating } \\
\text { from normal (if data } \\
\text { available) }\end{array}$ & $\begin{array}{l}\text { Any other } \\
\text { combination }\end{array}$ & $\begin{array}{l}\text { Large decline: Equivalent to a } \\
\text { loss of more than } 1 \% \text { per year } \\
\text { (indicative value MS may } \\
\text { deviate from if duly justified) } \\
\text { within period specified by MS } \\
\text { AND below 'favourable } \\
\text { reference population' } \\
\text { OR } \\
\text { More than } 25 \% \text { below } \\
\text { favourable reference population } \\
\text { OR } \\
\text { Reproduction, mortality and } \\
\text { age structure strongly deviating } \\
\text { from normal (if data available) }\end{array}$ & $\begin{array}{l}\text { No or insufficient } \\
\text { reliable information } \\
\text { available }\end{array}$ \\
\hline $\begin{array}{l}\text { Habitat for the } \\
\text { species }\end{array}$ & $\begin{array}{l}\text { Area of habitat is } \\
\text { sufficiently large (and } \\
\text { stable or increasing) } \\
\text { AND habitat quality is } \\
\text { suitable for the long } \\
\text { term survival of the } \\
\text { species }\end{array}$ & $\begin{array}{l}\text { Any other } \\
\text { combination }\end{array}$ & $\begin{array}{l}\text { Area of habitat is clearly not } \\
\text { sufficiently large to ensure the } \\
\text { long term survival of the } \\
\text { species } \\
\text { OR } \\
\text { Habitat quality is bad, clearly } \\
\text { not allowing long term survival } \\
\text { of the species }\end{array}$ & $\begin{array}{l}\text { No or insufficient } \\
\text { reliable information } \\
\text { available }\end{array}$ \\
\hline $\begin{array}{l}\text { Future prospects } \\
\text { (as regards to } \\
\text { population, range } \\
\text { and habitat } \\
\text { availability) }\end{array}$ & $\begin{array}{l}\text { Main pressures and } \\
\text { threats to the species } \\
\text { not significant; species } \\
\text { will remain viable on the } \\
\text { long-term }\end{array}$ & $\begin{array}{l}\text { Any other } \\
\text { combination }\end{array}$ & $\begin{array}{l}\text { Severe influence of pressures } \\
\text { and threats to the species; very } \\
\text { bad prospects for its future, } \\
\text { long-term viability at risk. }\end{array}$ & $\begin{array}{l}\text { No or insufficient } \\
\text { reliable information } \\
\text { available }\end{array}$ \\
\hline $\begin{array}{c}\text { Overall } \\
\text { assessment of CS }\end{array}$ & $\begin{array}{c}\text { All 'green' } \\
\text { OR } \\
\text { three 'green' and one } \\
\text { 'unknown' }\end{array}$ & $\begin{array}{l}\text { One or more } \\
\text { 'amber' but no } \\
\text { 'red' }\end{array}$ & One or more 'red' & $\begin{array}{l}\text { Two or more } \\
\text { 'unknown' } \\
\text { combined with } \\
\text { green or all } \\
\text { 'unknown' }\end{array}$ \\
\hline
\end{tabular}




\begin{tabular}{|c|c|c|c|c|}
\hline \multicolumn{3}{|l|}{ Parameter } & \multicolumn{2}{|l|}{ Conservation Status } \\
\hline & $\begin{array}{c}\text { Favourable } \\
\text { ('green') }\end{array}$ & $\begin{array}{c}\text { Unfavourable - } \\
\text { Inadequate } \\
\text { ('amber') }\end{array}$ & $\begin{array}{c}\text { Unfavourable - Bad } \\
\text { ('red') }\end{array}$ & $\begin{array}{l}\text { Unknown } \\
\text { (insufficient } \\
\text { information to } \\
\text { make an } \\
\text { assessment) }\end{array}$ \\
\hline Range & $\begin{array}{l}\text { Stable (loss and } \\
\text { expansion in balance) or } \\
\text { increasing AND not } \\
\text { smaller than the } \\
\text { 'favourable reference } \\
\text { range' }\end{array}$ & $\begin{array}{l}\text { Any other } \\
\text { combination }\end{array}$ & $\begin{array}{l}\text { Large decrease: Equivalent to a } \\
\text { loss of more than } 1 \% \text { per year } \\
\text { within period specified by MS } \\
\underline{\text { OR }} \\
\text { More than } 10 \% \text { below } \\
\text { 'favourable reference range' }\end{array}$ & $\begin{array}{l}\text { No or insufficient } \\
\text { reliable information } \\
\text { available }\end{array}$ \\
\hline $\begin{array}{l}\text { Area covered by } \\
\text { habitat type } \\
\text { within range }\end{array}$ & $\begin{array}{l}\text { Stable (loss and } \\
\text { expansion in balance) or } \\
\text { increasing AND not } \\
\text { smaller than the } \\
\text { 'favourable reference } \\
\text { area' AND without } \\
\text { significant changes in } \\
\text { distribution pattern } \\
\text { within range (if data } \\
\text { available) }\end{array}$ & $\begin{array}{l}\text { Any other } \\
\text { combination }\end{array}$ & $\begin{array}{l}\text { Large decrease in surface area: } \\
\text { Equivalent to a loss of more } \\
\text { than } 1 \% \text { per year (indicative } \\
\text { value MS may deviate from if } \\
\text { duly justified) within period } \\
\text { specified by MS } \\
\underline{\text { OR }} \\
\text { With major losses in } \\
\text { distribution pattern within } \\
\text { range } \\
\underline{\text { OR }} \\
\text { More than } 10 \% \text { below } \\
\text { 'favourable reference area' }\end{array}$ & $\begin{array}{l}\text { No or insufficient } \\
\text { reliable information } \\
\text { available }\end{array}$ \\
\hline $\begin{array}{l}\text { Specific } \\
\text { structures and } \\
\text { functions } \\
\text { (including typical } \\
\text { species) }\end{array}$ & $\begin{array}{l}\text { Structures and functions } \\
\text { (including typical } \\
\text { species) in good } \\
\text { condition and no } \\
\text { significant deteriorations } \\
\text { / pressures. }\end{array}$ & $\begin{array}{l}\text { Any other } \\
\text { combination }\end{array}$ & $\begin{array}{l}\text { More than } 25 \% \text { of the area is } \\
\text { unfavourable as regards its } \\
\text { specific structures and } \\
\text { functions (including typical } \\
\text { species) }\end{array}$ & $\begin{array}{l}\text { No or insufficient } \\
\text { reliable information } \\
\text { available }\end{array}$ \\
\hline $\begin{array}{l}\text { Future prospects } \\
\text { (as regards range, } \\
\text { area covered and } \\
\text { specific structures } \\
\text { and functions) }\end{array}$ & $\begin{array}{l}\text { The habitats prospects } \\
\text { for its future are } \\
\text { excellent / good, no } \\
\text { significant impact from } \\
\text { threats expected; long- } \\
\text { term viability assured. }\end{array}$ & $\begin{array}{l}\text { Any other } \\
\text { combination }\end{array}$ & $\begin{array}{l}\text { The habitats prospects are bad, } \\
\text { severe impact from threats } \\
\text { expected; long-term viability } \\
\text { not assured. }\end{array}$ & $\begin{array}{l}\text { No or insufficient } \\
\text { reliable information } \\
\text { available }\end{array}$ \\
\hline $\begin{array}{l}\text { Overall } \\
\text { assessment of CS }\end{array}$ & $\begin{array}{c}\text { All 'green' } \\
\text { OR } \\
\text { three 'green' and one } \\
\text { 'unknown' }\end{array}$ & $\begin{array}{c}\text { One or more } \\
\text { 'amber' but no } \\
\text { 'red' }\end{array}$ & One or more 'red' & $\begin{array}{l}\text { Two or more } \\
\text { 'unknown' } \\
\text { combined with } \\
\text { green or all } \\
\text { 'unknown' }\end{array}$ \\
\hline
\end{tabular}




\section{Bijlage 4 Geïnventariseerde beheerplannen}

\begin{tabular}{|c|c|c|c|c|c|c|c|}
\hline Nr. & Gebiedsnaam & Landschapstype & Provincie & Voortouwnemer & Oppervlakte (ha) & Richtlijn ${ }^{2}$ & Status beheerplan d.d. sep. '15 \\
\hline 1 & Waddenzee & Noordzee, Waddenzee en Delta & - & I\&M & 271,023 & $\mathrm{VR}+\mathrm{HR}$ & ontwerp \\
\hline 9 & Groote Wielen & Meren en Moerassen - Laagveen & FR & Provincie & 604 & $\mathrm{VR}+\mathrm{HR}$ & definitief \\
\hline 11 & Witte en Zwarte Brekken & Meren en Moerassen - Laagveen & FR & EZ & 433 & VR & definitief \\
\hline 12 & Sneekermeergebied & Meren en Moerassen - Laagveen & FR & EZ & 2,279 & VR & definitief \\
\hline 36 & Uiterwaarden Zwarte water en Vecht & Rivierengebied & OV & Provincie & 1,463 & $\mathrm{VR}+\mathrm{HR}$ & ontwerp \\
\hline 39 & Vecht en Beneden-Reggegebied & Rivierengebied / Hogere zandgronden & ov & Provincie & 4,105 & $\mathrm{HR}$ & ontwerp \\
\hline 40 & Engbertsdijksvenen & Hoogvenen - Resten hoogveenlandschap & OV & EZ & 997 & $\mathrm{VR}+\mathrm{HR}$ & ontwerp \\
\hline 42 & Sallandse Heuvelrug & Hogere zandgronden & OV & EZ & 2,217 & $\mathrm{VR}+\mathrm{HR}$ & ontwerp \\
\hline 47 & Achter de Voort, Agelerbroek \& Voltherbroek & Beekdalen & ov & EZ & 324 & $\mathrm{HR}$ & ontwerp \\
\hline 48 & Lemselermaten & Beekdalen & OV & Provincie & 55 & $\mathrm{HR}$ & ontwerp \\
\hline 50 & Landgoederen Oldenzaal & Hogere zandgronden & OV & Provincie & 578 & $\mathrm{HR}$ & ontwerp \\
\hline 51 & Lonnekermeer & Hogere zandgronden & OV & Provincie & 105 & $H R$ & ontwerp \\
\hline 53 & Buurserzand \& Haaksbergerveen & $\begin{array}{l}\text { Hogere zandgronden } \\
\text { Hoogvenen - Komvenen in dekzandlandschap }\end{array}$ & ov & Provincie & 1,249 & $\mathrm{HR}$ & ontwerp \\
\hline 54 & Witte Veen & Hoogvenen - Komvenen in dekzandlandschap & OV & Provincie & 290 & HR & ontwerp \\
\hline 58 & Landgoederen Brummen & Beekdalen & GE & Provincie & 677 & $\mathrm{HR}$ & ontwerp \\
\hline 62 & Willinks Weust & Hogere zandgronden & OV & EZ & 51 & $\mathrm{HR}$ & ontwerp \\
\hline 79 & Lepelaarplassen & Meren en Moerassen - Zeeklei & $\mathrm{FL}$ & Provincie & 356 & VR & definitief \\
\hline 98 & Westduinpark \& Wapendal & Duinen & $\mathrm{ZH}$ & Provincie & 247 & HR & definitief \\
\hline 99 & Solleveld \& Kapittelduinen & Duinen & $\mathrm{ZH}$ & Provincie & 729 & $\mathrm{HR}$ & definitief \\
\hline 100 & Voornes Duin & Duinen & $\mathrm{ZH}$ & Provincie & 1,432 & $\mathrm{VR}+\mathrm{HR}$ & ontwerp \\
\hline 101 & Duinen Goeree \& Kwade Hoek & Duinen & $\mathrm{ZH}$ & Provincie & 1,624 & $\mathrm{VR}+\mathrm{HR}$ & definitief \\
\hline 103 & Nieuwkoopse Plassen \& De Haeck & Meren en Moerassen - Laagveen & $\mathrm{ZH}$ & Provincie & 2,008 & $\mathrm{VR}+\mathrm{HR}$ & definitief \\
\hline 104 & Broekvelden, Vettenbroek \& Polder Stein & Meren en Moerassen - Laagveen & $\mathrm{ZH}$ & Provincie & 711 & VR & definitief \\
\hline 108 & Oude Maas & Rivierengebied & $\mathrm{ZH}$ & $\mathrm{I} \& \mathrm{M}$ & 474 & $\mathrm{HR}$ & ontwerp \\
\hline 111 & Hollands Diep & Rivierengebied & NB / ZH & I\&M & 4,224 & $\mathrm{VR}+\mathrm{HR}$ & ontwerp \\
\hline 113 & Voordelta & Noordzee, Waddenzee en Delta & $\mathrm{ZH} / \mathrm{ZE}$ & I\&M & 83,534 & $\mathrm{VR}+\mathrm{HR}$ & definitief \\
\hline 119 & Veerse Meer & Noordzee, Waddenzee en Delta & ZE & $\mathrm{I} \& \mathrm{M}$ & 2,539 & VR & ontwerp \\
\hline 127 & Markiezaat & Noordzee, Waddenzee en Delta & NB & Provincie & 1,832 & VR & ontwerp \\
\hline 151 & Abdij Lilbosch en voormalig Klooster Mariahoop & Hogere zandgronden & LI & Provincie & 15 & $\mathrm{HR}$ & definitief \\
\hline
\end{tabular}




\section{Bijlage 5 Enquête voortouwnemers}

\section{Vragen}

1. Naam en organisatie

2. Welke van de onderstaande documenten zijn toegepast voor de nadere uitwerking van de instandhoudingsdoelen in de beheerplannen? Bood dit document ook voldoende duidelijkheid? Gaf het document ook voldoende ruimte voor concretisering op gebiedsniveau?

3. Is er gebruik gemaakt van de kernopgaven uit het Natura 2000-doelendocument bij de uitwerking van de instandhoudingsdoelstellingen?

4. Worden er ook instandhoudingsdoelstellingen voor een combinatie van Natura 2000-gebieden (bv. binnen eenzelfde landschapstype) geformuleerd?

5. Wordt er rekening gehouden met de samenhang tussen de instandhoudingsdoelstellingen voor soorten en habitattypen binnen een gebied (als zijnde onderdeel van een systeem)?

6. Wordt er in het beheerplan een relatie gelegd met andere natuurbeleidsopgaven?

7. Wordt er in het beheerplan een relatie gelegd met andere maatschappelijke opgaven?

8. Zijn de instandhoudingsdoelen t.a.v. soorten en habitattypen nader uitgewerkt of te wel geconcretiseerd in omvang, ruimte en tijd? Zo nee, waarom niet? Zo ja hoe?

9. Is het duidelijk hoe men de instandhoudingdoelen gaat toetsen? Zo nee, waarom niet. Zo ja, hoe?

10. Is er een nulmeting uitgevoerd? Zo nee, waarom niet? Zo ja, hoe?

11. Krijgen bepaalde soorten of habitattypen voorrang boven anderen (prioritering t.a.v. soorten en habitattypen)?

12. Krijgen instandhoudingsdoelen op bepaalde locaties voorrang boven andere locaties (prioritering in de ruimte)?

13. Zijn er verschillende termijnstellingen verbonden aan de instandhoudingsdoelen (prioritering in de tijd)?

14. Is er een duidelijke koppeling gelegd tussen instandhoudingsdoelen en maatregelen? Of te wel wordt er per maatregel aangegeven welke doelen het dient?

15. Zijn de maatregelen gelokaliseerd?

16. Is er een termijn verbonden aan de uitvoering van de maatregelen?

17. Aanvullende opmerkingen 


\section{Resultaten}

Er hebben 8 personen op de digitale enquête gereageerd. Drie ervan hebben de enquête echter niet (of deels niet) ingevuld. In totaal zijn er daarom maar 5 reacties bruikbaar. De kwantitatieve resultaten van de enquête en de bijbehorende kwalitatieve opmerkingen kunnen niet één op één met de resultaten van de beheerplannen evaluatie vergeleken worden, omdat de respondenten mogelijk voor andere (niet geëvalueerde) beheerplannen voortouwnemer waren.

\section{Waar men tegen aan liep}

- Hoe omgaan met doelen in een dynamische natuur?

- Hoe omgaan met aanwijzingen voor slechts één vitale levensfunctie?

- Hoe omgaan met 'ten gunste van' formuleringen?

Kwaliteit profielendocumenten te slecht voor zinvol gebruik: het gaat hierbij om de profielendocumenten van habitattypen uit de 11-serie (op zee en in zoute kustwateren).

Weinig ruimte voor het maken van eigen keuzes t.a.v. bescherming van in Natura 2000-gebied aangetroffen habitattypen. Dit werd wel gesuggereerd in handreiking, maar blijkt er juridisch toch niet te zijn; dat wekte wat irritatie; is deels in de hand gewerkt door het feit dat bij vooral op het land gelegen Natura 2000-gebieden er in de regel meer keuzemogelijkheden zijn, terwijl de watergebieden voor vrijwel $100 \%$ van het areaal uit aangewezen habitattypen (of dan toch in ieder geval leefgebieden voor aangewezen soorten) bestaan, waardoor de juridische ruimte voor differentiatie in de praktijk veelal vrijwel ontbrak.

Belangrijke andere bron voor opstellen beheerplan is de kamerbrief van september 2011, waarin uitdrukkelijk (om 'koppen' op de EU-wetgeving te vermijden) werd gesteld dat voor de eerste beheerplanperiode het voorkómen van verdere verslechtering voldoende was en dat verbeterdoelen of niet behaalde behoudsdoelen dus nog even dienden te worden uitgesteld.

\section{Prioritering van doelen}

Er was niet altijd sprake van noodzaak om bepaalde doelen voorrang te geven. Anderen gaven aan dat prioritering plaatsvindt a.d.h.v. de sense of urgency en prioritaire soorten of habitattypen.

Prioritering in de tijd wordt drie keer toegelicht. Twee keer wordt aangegeven dat voor de eerste planperiode de behoudsdoelen voorop staan en uitbreidingsdoelen en kwaliteitsverbetering in de navolgende planperioden aan de orde komen. Eén keer wordt aangegeven dat men een systeemgerichte aanpak hanteert, waarbij alles in een keer wordt gedaan, omdat men streeft naar een evenwicht situatie (tot zover die in dynamische natuurgebieden kan bestaan).

\section{Afstemming op groter schaalniveau tussen doelen (intern)}

Afstemming op grotere schaalniveau wordt alleen gedaan als dit in de aanwijzingsbesluiten is benoemd. Er wordt beredeneert dat de instandhoudingsdoelen, zoals vastgesteld in het aanwijzingsbesluit bij het opstellen van de beheerplannen als uitgangspunt zijn gehanteerd. Er zijn geen andere doelen toegevoegd.

\section{Samenhang tussen doelen binnen gebied}

Er wordt door alle respondenten aangegeven dat er rekening wordt gehouden met de samenhang tussen de instandhoudingsdoelstellingen voor soorten en habitattypen binnen een gebied (als zijnde onderdeel van een systeem).

Alle respondenten geven aan dat de maatregelen worden gelinkt aan de instandhoudingsdoelstellingen, dat ze in ruimte worden geplaats (zij het soms niet concreet, maar in zoekgebieden) en dat ze aan een termijn zijn verbonden (in termen van beheerplanperiodes). 


\section{Verdere opmerkingen}

Er was wel vrij veel guidance, maar de duidelijkheid ervan liet vaak wel wat te wensen over. Aan de andere kant was juist hierdoor wel meestal vrij veel ruimte voor maatwerk (concretisering op gebiedsniveau). Er werd wel veel kennis en inzicht in de materie van ecologie en natuurwetgeving gevraagd van de voortouwnemer.

Gebiedsgerichte verbetering: Ruimte voor concretisering op gebiedsniveau is op zich positief, maar het betekent wel veel werk voor de voortouwnemer, maar nadeel is wel dat er moeilijker aan de landelijke lijnen vastgehouden kan worden. 
Wageningen Environmental Research Postbus 47

6700 AA Wageningen

T 0317480700

www.wur.nl/environmental-research

Wageningen Environmental Research

Rapport 2779A

ISSN 1566-7197
De missie van Wageningen University \& Research is 'To explore the potential of nature to improve the quality of life'. Binnen Wageningen University \& Research bundelen Wageningen University en gespecialiseerde onderzoeksinstituten van Stichting Wageningen Research hun krachten om bij te dragen aan de oplossing van belangrijke vragen in het domein van gezonde voeding en leefomgeving. Met ongeveer 30 vestigingen, 5.000 medewerkers en 10.000 studenten behoort Wageningen University \& Research wereldwijd tot de aansprekende kennisinstellingen binnen haar domein. De integrale benadering van de vraagstukken en de samenwerking tussen verschillende disciplines vormen het hart van de unieke Wageningen aanpak. 



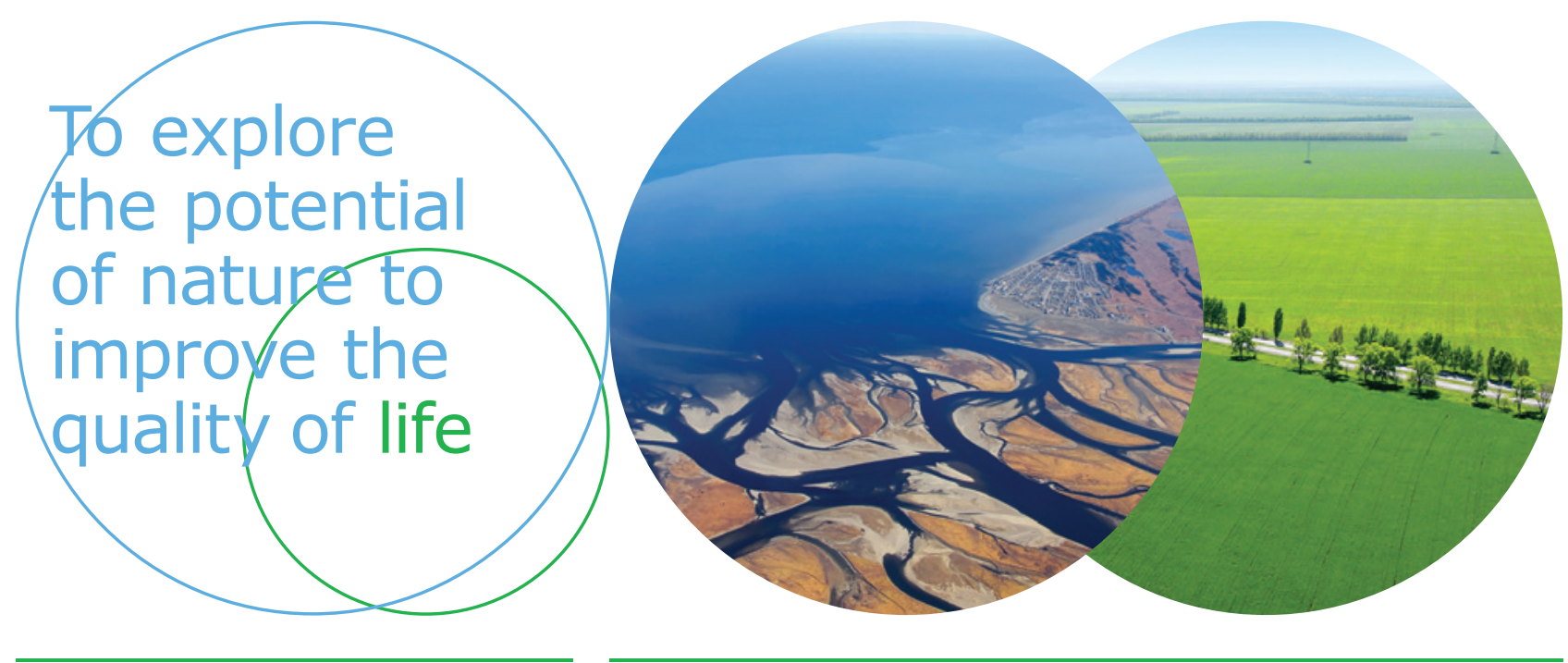

Wageningen Environmental Research Postbus 47

$6700 \mathrm{AB}$ Wageningen

T 317480700

www.wur.nl/environmental-research

Rapport 2779A

ISSN 1566-7197
De missie van Wageningen University \& Research is 'To explore the potential of nature to improve the quality of life'. Binnen Wageningen University \& Research bundelen Wageningen University en gespecialiseerde onderzoeksinstituten van Stichting Wageningen Research hun krachten om bij te dragen aan de oplossing van belangrijke vragen in het domein van gezonde voeding en leefomgeving. Met ongeveer 30 vestigingen, 5.000 medewerkers en 10.000 studenten behoort Wageningen University \& Research wereldwijd tot de aansprekende kennisinstellingen binnen haar domein. De integrale benadering van de vraagstukken en de samenwerking tussen verschillende disciplines vormen het hart van de unieke Wageningen aanpak. 